\title{
Discovery of Novel Adenosine Receptor Agonists that Exhibit Subtype Selectivity
}

Anthony Knight, ${ }^{\dagger, \#}$ Jennifer L. Hemmings, ${ }^{\ddagger}, \#$ Ian Winfield, ${ }^{\mathrm{q}, \perp}$ Michele Leuenberger, ${ }^{\ddagger}$ Eugenia Frattini, ${ }^{\perp}$

Bruno G. Frenguelli, ${ }^{\S}$ Simon J. Dowell, ${ }^{\prime}$ Martin Lochner, ${ }^{*}+$ and Graham Ladds $*, \perp$

${ }^{\dagger}$ Systems Biology Doctoral Training Centre, University of Warwick, Coventry, CV4 7AL, UK.

Department of Chemistry and Biochemistry, University of Bern, 3012 Bern, Switzerland.

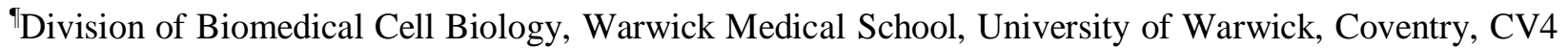

7AL, UK.

${ }^{\S}$ School of Life Sciences, University of Warwick, Coventry CV4 7AL, UK.

"Department of Platform Technology and Science, GlaxoSmithKline, Hertfordshire, SG1 2NY, UK.

${ }^{\perp}$ Department of Pharmacology, University of Cambridge, Tennis Court Road, Cambridge CB2 1PD, UK.

Running Title: Investigating adenosine receptor selectivity of $N^{6}$-modified agonists.

Keywords: GPCRs; adenosine receptor; selectivity; G proteins; yeast. 


\begin{abstract}
A series of $N^{6}$-bicyclic and $N^{6}$-(2-hydroxy)cyclopentyl derivatives of adenosine were synthesized as novel $A_{1} R$ agonists and their $A_{1} R / A_{2} R$ selectivity assessed using a simple yeast screening platform. We observed that the most selective, high potency ligands were achieved through $N^{6}$-adamantyl substitution in combination with 5'-N-ethylcarboxamido or 5'-hydroxymethyl groups. In addition, we determined that 5'(2-fluoro)thiophenyl derivatives all failed to generate a signaling response despite showing an interaction with the $A_{1} R$. Some selected compounds were also tested on $A_{1} R$ and $A_{3} R$ in mammalian cells revealing that four of them are entirely $\mathrm{A}_{1} \mathrm{R}$-selective agonists. By using in silico homology modeling and ligand docking, we provide insight into their mechanisms of recognition and activation of the $A_{1} R$. We believe that given the broad tissue distribution, but contrasting signaling profiles, of adenosine receptor subtypes these compounds might have therapeutic potential.
\end{abstract}




\section{Introduction}

Adenosine receptors (ARs) belong to the family of G protein-coupled receptors (GPCRs) and exist as four different subtypes, $\mathrm{A}_{1}, \mathrm{~A}_{2 \mathrm{~A}}, \mathrm{~A}_{2 \mathrm{~B}}$ and $\mathrm{A}_{3}$. All subtypes respond to the purinergic nucleoside adenosine, but they have a wide and varying tissue distribution. Many ARs have been linked to cardiovascular, respiratory and inflammatory disorders. ${ }^{1}$ Furthermore, in the central nervous system they have been implicated in acute pathological conditions such as epilepsy, hypoxia and ischemia, ${ }^{2,3}$ and chronic neurodegenerative disorders, such as Parkinson's, Alzheimer's and Huntington's diseases. ${ }^{4}$ In human cells, the $A_{1} R$ and $A_{3} R$ predominantly couple to the $G \alpha_{i}$ family of $G$ proteins, inhibiting the production of cAMP, while the $\mathrm{A}_{2} \mathrm{R}$ subtypes couple to the $\mathrm{G} \alpha_{\mathrm{s}}$ subunit, stimulating adenylate cyclase to elevate cAMP levels. Given their common ligands, diametrically opposed effects and overlapping tissue distribution the ARs have been the focus of extensive research to discover subtype selective ligands. However, limitations of mammalian systems can hinder the testing and development of these compounds. For instance, the $\mathrm{A}_{1} \mathrm{R}$ can signal through the $\mathrm{G} \alpha_{i 1}, \mathrm{G \alpha}_{\mathrm{i} 3}$ and $\mathrm{G} \alpha_{\mathrm{o}}{ }^{5}$ but it is currently difficult to differentiate between these effectors in an in vivo mammalian cell-based assay.

Most of the known AR agonists are based on the adenosine scaffold and receptor subtype selectivity can be achieved by substituting the purine ring of the nucleoside at positions C-2 and/or $N^{6}$ with appropriate functional groups. For instance, substitution of the $N^{6}$-position with bulky cycloalkyl- and bicycloalkyl groups has resulted in $\mathrm{A}_{1} \mathrm{R}$-selective agonists. ${ }^{6-10}$ Introduction of a wide range of $N^{6}$-substituents is conveniently achieved by nucleophilic aromatic substitution of the corresponding 6-chloro purine precursor with primary or secondary amines. The ribose moiety, in particular at the C-2', C-3' and C-5' positions, have also been the subject of many modifications which can influence $A_{1} R$ affinity, selectivity and efficacy. ${ }^{8,11,12}$ 5'-Carboxamido adenosine derivatives, such as the prototypical AR agonist 5'- $N$ ethylcarboxamidoadenosine (NECA), among many other examples, are known to be potent activators. More bulky groups, such as substituted 5'-thioaryl and 5'-oxoaryl moieties have also been explored and these studies have provided novel $\mathrm{A}_{1} \mathrm{R}$-selective and potent agonists. ${ }^{13,14}$ In light of this, we designed a 
series of adenosine analogues that feature different cyclic and bicyclic substituents at the $N^{6}$ of the purine ring and various functional groups at the $\mathrm{C}^{-5}$ ' of the ribose in order to assess the effect of these modifications on AR activity and subtype selectivity.

$\mathrm{We}^{15-20}$ and others ${ }^{5,21-23}$ have previously described the use of modified Saccharomyces cerevisiae strains containing chimeric (yeast-human) G protein alpha subunits to functionally couple heterologously expressed GPCRs. Specifically, the chimeric G proteins enable mammalian GPCRs to functionally couple to the yeast-mating pathway. This pathway includes a reporter (FUS1-lacZ) gene providing a quantitative assay for GPCR activation. ${ }^{16}$ The yeast platform provides a simple, affordable and robust assay with which to identify novel GPCR ligands and their interactions with a single effector. ${ }^{17,24,25}$ This system has also been established to study $A_{1} R, A_{2 A} R$ and $A_{2 B} R$ in a number of $G$ protein backgrounds, ${ }^{5,18,21-23}$ although evidence of functional couplings of the $A_{3} R$ has not been reported.

In this study we exploit the yeast system to characterize novel synthetic adenosine derivatives for their agonist activity against the $A_{1} R, A_{2 A} R$ and $A_{2 B} R$. We explored subtype selectivity further at the $A_{1} R$ and $A_{3} R$ in mammalian $\mathrm{CHO}-\mathrm{K} 1$ cells for the compounds that were active against the $A_{1} R$ in the yeast screen. Moreover, we use homology modeling and docking to gain insight into the binding of our agonists at the $\mathrm{A}_{1} \mathrm{R}$. Our yeast-based screen and mammalian cell assays have identified novel adenosine nucleosides exhibiting interesting $\mathrm{A}_{1} \mathrm{R}$ selective profiles. Hence, they constitute valuable tool compounds for cellular studies and might have therapeutic potential.

\section{Results and Discussion}

\section{Chemistry}

Known compounds $5,{ }^{26} \mathbf{6}^{27}$ and $\mathbf{7}^{28}$ have previously been shown to be selective for the $\mathrm{A}_{1} \mathrm{R}$ with respect to their binding affinity. These analogues were prepared for assessment using our yeast-based assay. Bulky bicyclic groups have been highlighted as beneficial for $A_{1} R$ selectivity, ${ }^{7-10}$ so we also prepared novel 
compound 9. Intermediate 2 was required for efficient generation of the analogues (Scheme 1). This was synthesized according to the procedure adopted by Kotra et al. ${ }^{29}$ with minor experimental modifications.

\section{Scheme 1. Synthesis of Adenosine Derivatives ${ }^{a}$}

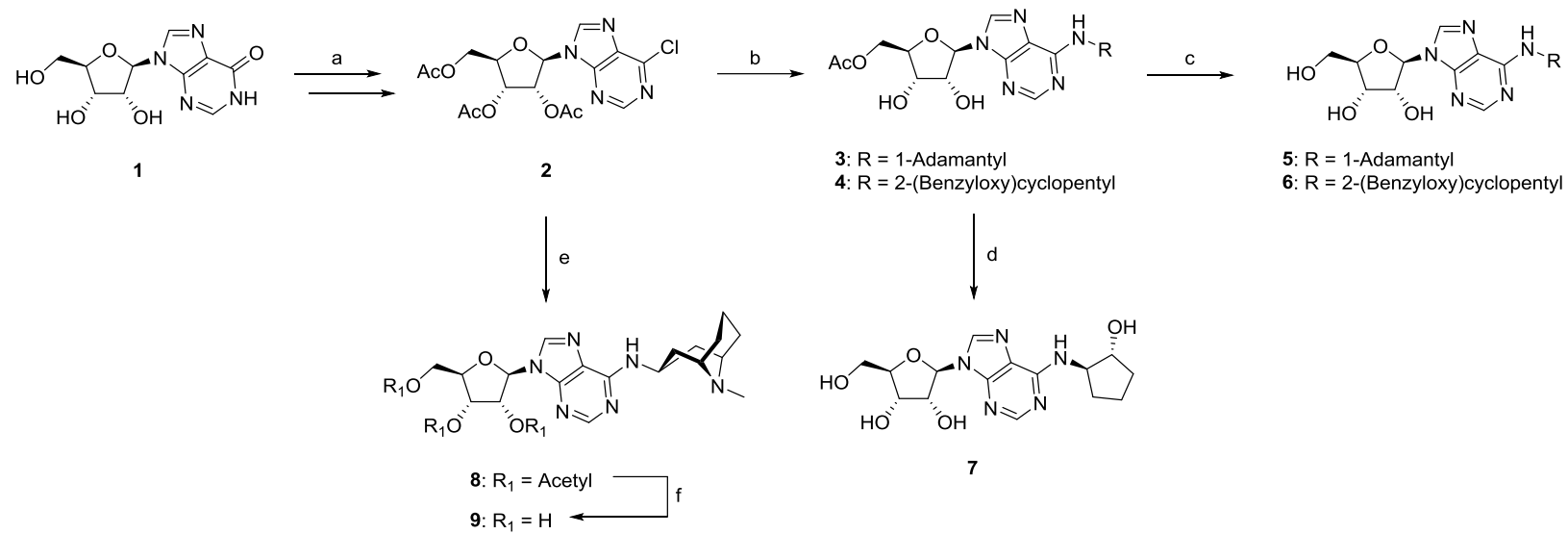

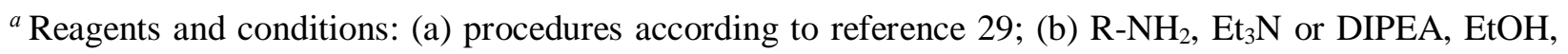
reflux, $18 \mathrm{~h}$ to 5 days (for specific conditions and yields see Experimental Section); (c) $\mathrm{K}_{2} \mathrm{CO}_{3}, \mathrm{MeOH}$, rt, 3 h, 99\%; (d) 4, Pd(OH) 2 , cyclohexene, ethanol, reflux, 18 h, 99\%; (e) (1R,3r,5S)-9-methyl-9azabicyclo[3.3.1]nonan-3-amine, DIPEA, EtOH, reflux, 18 h, 54\%; (f) $\mathrm{K}_{2} \mathrm{CO}_{3}, \mathrm{MeOH}, \mathrm{rt}, 3$ h, $99 \%$.

Aromatic substitution of the $N^{6}$-chloro group with 1-adamantylamine or $(1 R, 2 R)$-1-amino-2benzyloxycyclopentane was carried out in the presence of triethylamine or Hünig's base. This resulted in partial deacetylation to give the monoacetylated products ( 3 and $\mathbf{4})$, which could be attributed to the use of excess base. The presence of the acetyl on the primary alcohol was confirmed using ${ }^{1} \mathrm{H}$ NMR and was then removed using potassium carbonate in methanol to give $\mathbf{5}$ and $\mathbf{6}$ in quantitative yield. The choice of base did not appear to have an effect on the reaction. Attempts to directly remove the benzyl group from $\mathbf{6}$ using hydrogenolysis returned unreacted starting material. However, treatment of monoprotected 4 with Pearlman's catalyst and cyclohexene afforded 7. Interestingly, aromatic substitution with $(1 R, 3 r, 5 S)$-9- 
methyl-9-azabicyclo[3.3.1]nonan-3-amine (granatanamine) using less base did not result in deacetylation and afforded the expected product $\mathbf{8}$. Deprotection was again carried out with potassium carbonate and methanol. Granatanamine was prepared according to a procedure previously developed in our group. ${ }^{30}$

Despite the widespread use of 5'-N-ethylcarboxamidoadenosine (NECA) as an $\mathrm{A}_{1} \mathrm{R}$ agonist we found that the analogous cyclopentyl (21) and adamantyl (16) congeners were novel compounds and to the best of our knowledge untested at the $A_{1} R$. This is possibly a consequence of the non-selective nature of NECA at the AR subtypes. ${ }^{31}$ In this case intermediate $\mathbf{1 0}$ was required to allow generation of novel analogues (Scheme 2).

\section{Scheme 2. Synthesis of Novel NECA Derivatives ${ }^{a}$}

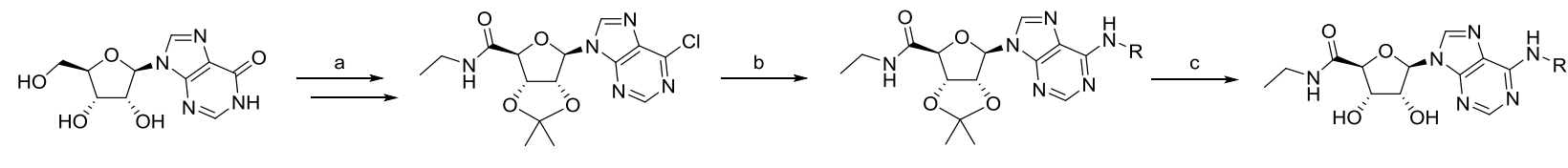

1

10

$11-15$

$16-20$
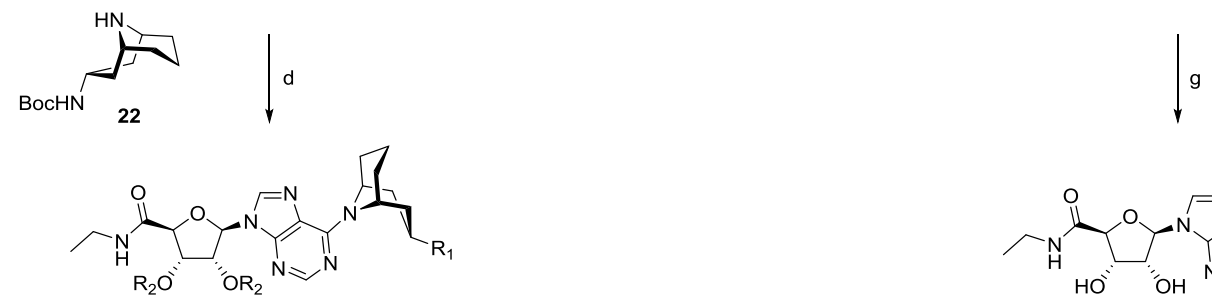

23: $\mathrm{R}_{1}=\mathrm{NHBoc}, \mathrm{R}_{2}=\mathrm{CMe}_{2} \quad \mathrm{e}$
24: $\mathrm{R}_{1}=\mathrm{NH}_{2}, \mathrm{R}_{2}=\mathrm{H}$
25: $\mathrm{R}_{1}=\mathrm{NMe}_{2}, \mathrm{R}_{2}=\mathrm{H}$

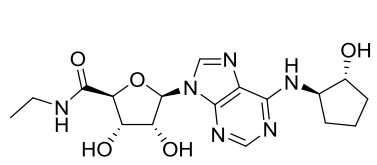

21

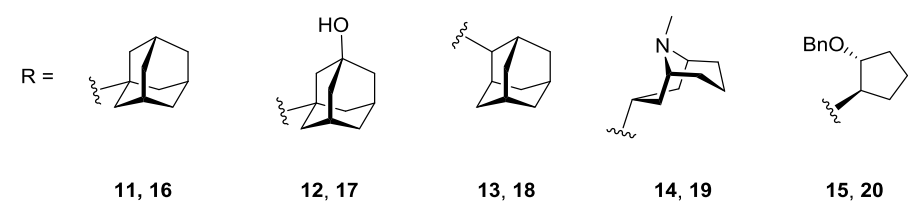

${ }^{a}$ Reagents and conditions: (a) procedures according to reference 32; (b) $\mathrm{R}_{-} \mathrm{NH}_{2}, \mathrm{Et}_{3} \mathrm{~N}$ or DIPEA, EtOH, reflux, $18 \mathrm{~h}$ to 5 days (for specific conditions and yields see Experimental Section); (c) acetic acid, water, $80{ }^{\circ} \mathrm{C}, 18$ h, 99\%; (d) tert-butyl-9-azabicyclo[3.3.1]nonan-3-yl carbamate (22), DIPEA, EtOH, reflux, 18 
h, 85\%; (e) acetic acid, water, $80{ }^{\circ} \mathrm{C}, 18 \mathrm{~h}, 99 \%$; (f) formic acid, formaldehyde (37\% aq.), reflux, $18 \mathrm{~h}$, 63\%; (g) 20, $\mathrm{Pd}(\mathrm{OH})_{2}$, cyclohexene, ethanol, reflux, 18 h, $99 \%$.

The amide building block $\mathbf{1 0}$ was prepared from $\mathbf{1}$ as previously reported by Middleton et al.. ${ }^{32}$ Displacement of the chloride in $\mathbf{1 0}$ with the appropriate amine in the presence of either Hünig's base or triethylamine gave intermediates 11-15. This reaction proceeded with ease in refluxing ethanol overnight in the case of 13-15, however all 1-adamantyl analogues required one week at reflux to generate sufficient quantities of desired compounds. Interestingly, the 2-adamantylamine reaction was complete within one day. Acetonide deprotection was achieved by heating overnight in acetic acid and water to generate 16-20 with quantitative yields observed. Removal of the benzyl protecting group from $\mathbf{2 0}$ with palladium hydroxide and cyclohexene to generate $\mathbf{2 1}$ proceeded in quantitative yield. We decided to prepare analogues 24 and 25 with the alternative bicyclic architecture to allow us to probe the necessity for a secondary amine at the adenine $N^{6}$ position. Chloride $\mathbf{1 0}$ was reacted with granatyl secondary amine $\mathbf{2 2}$, which was prepared according to a literature protocol. ${ }^{33}$ Like the adamantyl analogues, this reaction was very slow and required reflux for one week to generate sufficient quantities of product to give 23. Concomitant deprotection of the acetonide and Boc group occurred on treatment with acetic acid and water to give $\mathbf{2 4}$. The dimethylamine 25 was then prepared using formic acid and formaldehyde.

Given the prior studies on CVT-3619 (37) showing that it is a specific partial agonist at the $\mathrm{A}_{1} \mathrm{R}^{14}$ we prepared this compound for assessment using our yeast-based assay and planned to prepare new analogues with the 2 -fluorothiophenol group at the $\mathrm{C}-5^{\prime}$ ' position of the ribose ring. In alignment with our strategy for adenosine and NECA analogues we required chloride 27, which would allow efficient generation of analogues with various cyclic groups at the $N^{6}$ position of the adenine (Scheme 3). Primary chloride 27 was prepared from protected 26 using Appel conditions according to the previously reported procedure. ${ }^{34}$ Treatment with 2-fluorothiophenol and sodium hydride gave $\mathbf{2 8}$ in $48 \%$ yield and subsequent chlorination with our previously adopted conditions of thionyl chloride and DMF gave $\mathbf{2 9}$ in $88 \%$ yield. 
Introduction of the cyclic component was accomplished by reacting with the appropriate primary amine in the presence of DIPEA or triethylamine to give 30-33. Again, preparation of the adamantyl analogue required one week at reflux to obtain the product in sufficient yield. Initial attempts to directly remove the benzyl protecting group from $\mathbf{3 2}$ with palladium hydroxide and cyclohexene to generate $\mathbf{3 7}$ were unsuccessful. However, 6-chloropurine 29 reacted readily with $(1 R, 2 R)$-2-aminocyclopentanol to generate the desired product directly. Acetonide deprotection with acetic acid and water at reflux generated final compounds $\mathbf{3 4 - 3 7}$ in excellent yields.

Scheme 3. Synthesis of CVT-3619 and New Derivatives ${ }^{a}$

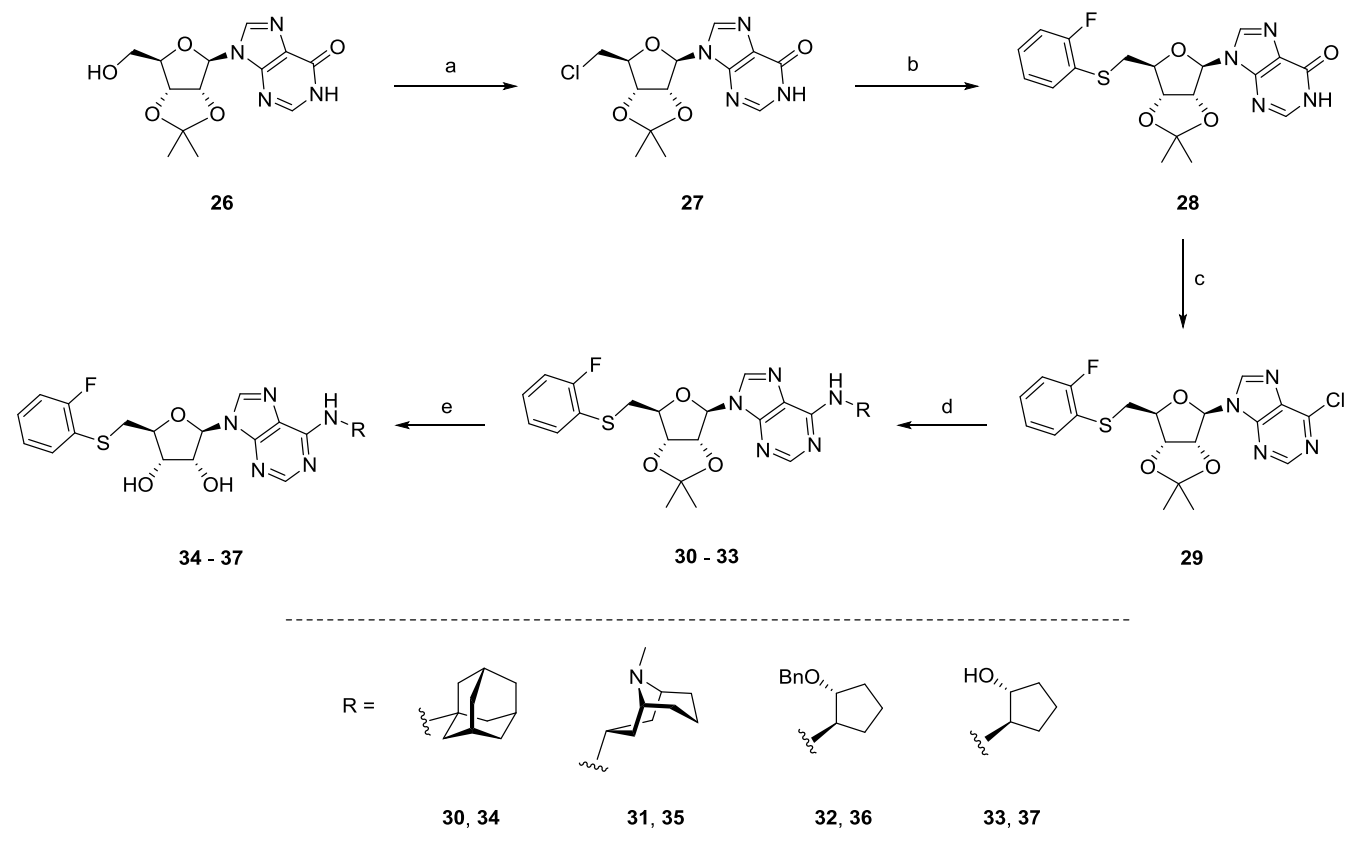

${ }^{a}$ Reagents and conditions: (a) $\mathrm{CCl}_{4}, \mathrm{PPh}_{3}, \mathrm{DMF}, \mathrm{rt}, 18 \mathrm{~h}, 53 \%$; (b) 2-fluorothiophenol, $\mathrm{NaH}, \mathrm{DMF}, 0{ }^{\circ} \mathrm{C}$ to

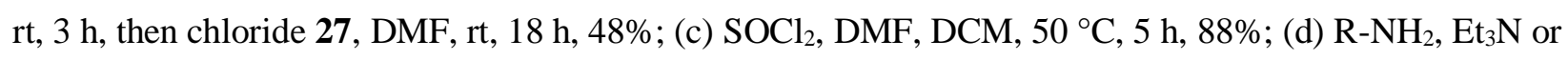
DIPEA, EtOH, reflux, 18 h to 3 days (for specific conditions and yields see Experimental Section); (e) acetic acid, water, $80^{\circ} \mathrm{C}, 18 \mathrm{~h}, 99 \%$. 


\section{Biological Activity}

We expressed all four AR subtypes, under the control of the constitutive GAPDH promoter, in a panel of transplant yeast strains engineered to contain chimeric $\mathrm{G} \alpha$-subunits in which the $5 \mathrm{C}$-terminal amino acids of $\mathrm{Gpa} 1 \mathrm{p}$ have been replaced with those mammalian $\mathrm{G} \alpha_{\mathrm{q}}, \mathrm{G} \alpha_{12}, \mathrm{G} \alpha_{\mathrm{o}}, \mathrm{G} \alpha_{\mathrm{i} 1 / 2}, \mathrm{G} \alpha_{\mathrm{i} 3}, \mathrm{G} \alpha_{\mathrm{z}}$ and $\mathrm{G} \alpha_{\mathrm{s}}$. Efficient trafficking of the $A_{1} R, A_{2 A} R$ and $A_{2 B} R$ to the cell surface in yeast cells was confirmed using modified receptors engineered to contain a GFP fluorophore at the C-terminus (Figure 1A). NECA is a nonsubtype selective AR agonist and was used to determine through which $\mathrm{G} \alpha$-subunits each receptor signaled. Yeast cells were exposed to $100 \mu \mathrm{M}$ NECA for 16 hours and reporter gene activity (as measured through $\beta$-galactosidase production) was determined (Figure 1B-D).
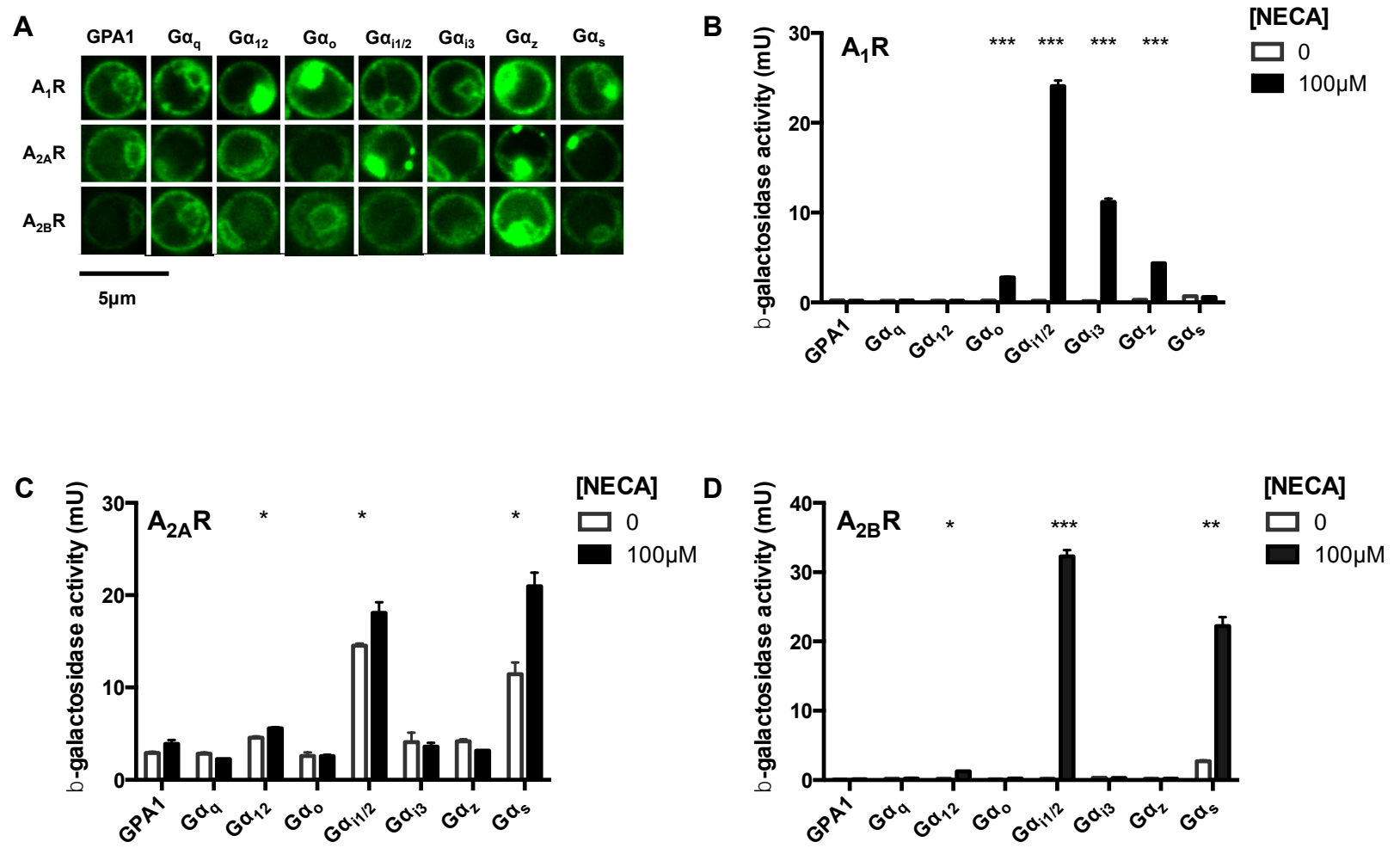

Figure 1. NECA-activated yeast-mating pathway via specific $A R / G \alpha$ protein chimeras. (A) A C-terminal GFP tag was engineered onto the $\mathrm{A}_{1} \mathrm{R}, \mathrm{A}_{2 \mathrm{~A}} \mathrm{R}$ and $\mathrm{A}_{2 \mathrm{~B}} \mathrm{R}$ and expression at the plasma membrane was confirmed using fluorescence microscopy. Scale bar $=5 \mu \mathrm{m}$. (B-D) Yeast strains expressing the human (B) 
$A_{1} R$, (C) $A_{2 A} R$ (D) $A_{2 B} R$ were stimulated with 0 or $100 \mu \mathrm{M}$ NECA for $16 \mathrm{~h}$ and assayed for the activation of the FUS1-lacZ reporter gene as previously described. ${ }^{15-17,19} \beta$-galactosidase units $(\mathrm{mU})$ are expressed as the ratio of $o$-nitrophenol product to cell density (determined colorimetrically; see Experimental Section). Data are the mean of 5 independent experiments \pm SEM. Data were determined as significantly different from the non-ligand response using Student's $t$-test where ${ }^{*}, p<0.05, * *, p<0.01, * * *, p<0.001$.

Consistent with previous reports ${ }^{5,22}$ the $\mathrm{A}_{1} \mathrm{R}$ generated significant $(p<0.05)$ responses in strains expressing G protein chimeras corresponding to $\mathrm{G} \alpha_{o}, \mathrm{G}_{\mathrm{i} 1}$ and $\mathrm{G} \alpha_{\mathrm{i} 3}$ (Figure 1B). In addition, we also report for the first time, functional coupling of the $A_{1} R$ signaling through the GPA1/G $\alpha_{z}$ transplant. Signaling was not observed via GPA1/G $\alpha_{\mathrm{q}}$, GPA1/G $\alpha_{12}$ or GPA1/G $\alpha_{s}$ or the unmodified Gpa1p ( $\mathrm{n} \geq 16$ isolates screened for functionality). Further, we observed that the $A_{2 A} R$ and $A_{2 B} R$ (Figure $1 C$ and $1 D$ ) signaled through both GPA1/G $\alpha_{s}$ and GPA1/G $\alpha_{i 1}$ but we failed to identify any functional coupling for the $A_{3} R$ in our panel of strains (Supplementary Figure S1). Moreover, we report that, the $A_{2 A} R$ displayed significantly elevated levels of ligand-independent signaling which is consistent with previous observations in yeast. ${ }^{18}$ While we have observed that these GPCRs can couple to a number of different Gpalp chimeras, we have chosen to focus on the ones that are widely reported to be the most physiologically relevant in mammalian cells. Consequently, the $\mathrm{A}_{1} \mathrm{R}-\mathrm{GPA} 1 / \mathrm{G}_{\mathrm{i}}, \mathrm{A}_{2 \mathrm{~A}} \mathrm{R}-\mathrm{GPA} 1 / \mathrm{G} \alpha_{\mathrm{s}}$ and $\mathrm{A}_{2 \mathrm{~B}} \mathrm{R}-\mathrm{GPA} 1 / \mathrm{G} \alpha_{\mathrm{s}}$ strains were chosen for further compound characterization.

Subtype Selectivity of Adenosine Derivatives in Yeast. Having identified yeast strains that functionally express the $A_{1} R, A_{2 A} R$ and $A_{2 B} R$, we sought to validate their pharmacology in response to a range of agonists. Dose-response curves were determined for NECA, adenosine, 2-chloro- $N^{6}$ cyclopentyladenosine (CCPA) and CGS-21680 (Figure 2) using the yeast reporter assay. Sigmoidal doseresponse curves were observed allowing the maximum response $\left(E_{\max }\right)$ and potency $\left(\mathrm{pEC}_{50}\right)$ to be determined (Table 1). NECA, adenosine and CCPA are full agonists at the $\mathrm{A}_{1} \mathrm{R}$ ( $E_{\max }$ compared with NECA by one-way ANOVA, $p>0.05$ ) but have differing potencies (Table 1). This generates a rank order of 
potency for the ligands of CCPA > NECA > adenosine. CGS-21680 had a much lower potency than the other ligands $\left(\mathrm{pEC}_{50}=3.2 \pm 0.1\right)$ and failed to reach a maximal response. While the overall potency values are lower than observed in mammalian cells, the rank order of the ligands is conserved between yeast and mammalian systems. ${ }^{35}$ Application of the operational model of pharmacological agonism ${ }^{36}$ enabled calculation of the ligand binding affinity $\left(\mathrm{pK}_{\mathrm{A}}\right)$ and efficacy $(\tau)$ (Table 2$)$. In comparison to NECA, both adenosine and CCPA have a greater $\mathrm{pK}_{\mathrm{A}}$ and a reduced $\tau$.

A

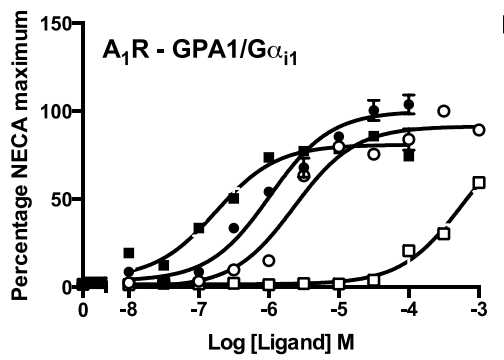

D

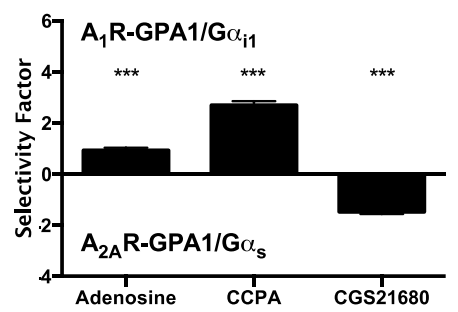

B

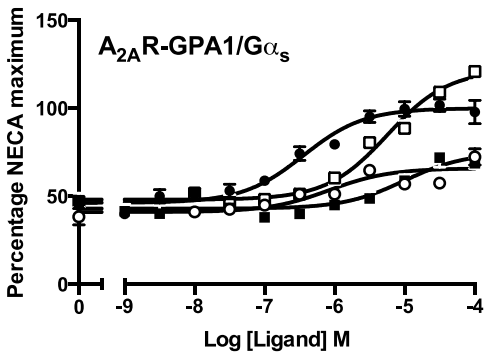

E

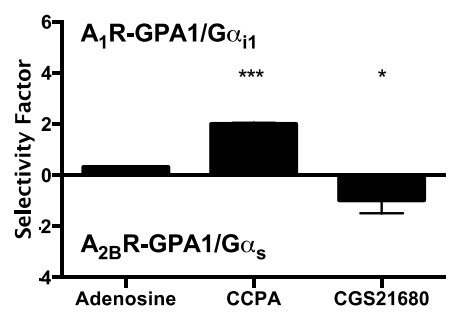

C

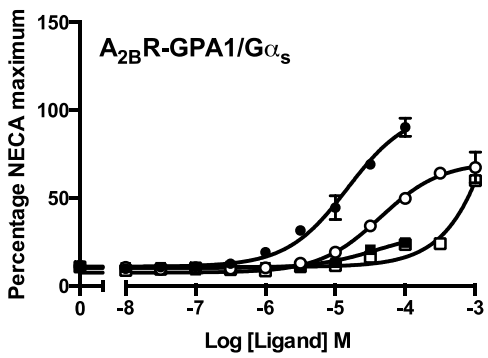

$\mathbf{F}$

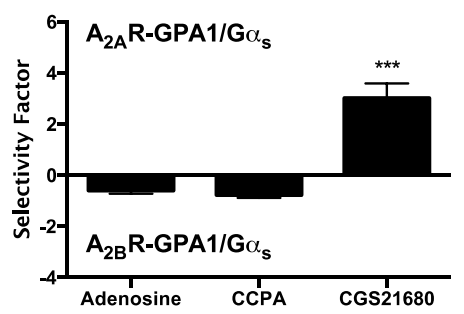

Figure 2. AR agonists display receptor subtype selectivity. Dose-response curves for various AR agonists were generated from yeast strains expressing (A) $A_{1} R$, (B) $A_{2 A} R$ and (C) $A_{2 B} R$ following stimulation for $16 \mathrm{~h}$ with $(\bullet)$ NECA, (०) adenosine, ( $\bullet$ CCPA or ( $\square$ ) CGS-21680. Activation of the reporter gene was calculated and is expressed as the percentage of the maximum response achieved when cells were stimulated with the reference agonist NECA. (D-F) Receptor selectivity was calculated as the change in log $\left(\tau / \mathrm{K}_{\mathrm{A}}\right)$, relative to NECA, for the data in A-C. Data were determined as statistically different $(* *, p<0.01$, ***, $p<0.001)$ from NECA, using a one-way ANOVA with Bonferroni's post-test. All data are mean of 58 independent experiments \pm SEM. 
Table 1. Potency $\left(\mathrm{pEC}_{50}\right)$ and Maximal Response $\left(\mathrm{E}_{\max }\right)$ of Reference Compounds and Synthetic Adenosine Derivatives at $A_{1} R, A_{2 A} R$ and $A_{2 B} R$ as measured in Yeast ${ }^{a}$

\begin{tabular}{|c|c|c|c|c|c|c|c|c|}
\hline \multirow{2}{*}{ Compd } & \multirow{2}{*}{$\mathbf{R}_{1}$} & \multirow{2}{*}{$\mathbf{R}_{2}$} & \multicolumn{2}{|c|}{$\mathbf{A}_{1} \mathbf{R}$} & \multicolumn{2}{|c|}{$\mathbf{A}_{2 \mathrm{~A}} \mathbf{R}$} & \multicolumn{2}{|c|}{$\mathbf{A}_{2 \mathrm{~B}} \mathbf{R}$} \\
\hline & & & $\mathrm{pEC}_{50}{ }^{b}$ & $\mathbf{E}_{\max }{ }^{c}$ & $\mathrm{pEC}_{50}{ }^{b}$ & $\mathbf{E}_{\max }{ }^{c}$ & $\mathrm{pEC}_{50}{ }^{b}$ & $\mathbf{E}_{\max }{ }^{c}$ \\
\hline NECA & -CONHEt & $-\mathrm{NH}_{2}$ & $6.0 \pm 0.1$ & $100 \pm 2.4$ & $6.47 \pm 0.2$ & $100 \pm 2.0^{*}$ & $4.83 \pm 0.1$ & $100 \pm 3.8$ \\
\hline Adenosine & $-\mathrm{CH}_{2} \mathrm{OH}$ & $-\mathrm{NH}_{2}$ & $5.6 \pm 0.1^{*}$ & $91.4 \pm 2.8$ & $5.24 \pm 0.8$ & $65.9 \pm 1.7^{* *}$ & $4.29 \pm 0.1$ & $70.4 \pm 2.9^{* *}$ \\
\hline CСРА & - & - & $6.7 \pm 0.1^{* * *}$ & $80.9 \pm 2.2$ & $5.00 \pm 0.2$ & $74.7 \pm 4.9$ & $4.14 \pm 0.1$ & $30.6 \pm 2.0^{* * *}$ \\
\hline CGS-21680 & - & - & $3.2 \pm 0.1^{* * *}$ & $91.3 \pm 14.1$ & $4.70 \pm 0.1^{*}$ & $121.7 \pm 4.1$ & $2.20 \pm 0.6^{* * *}$ & $59.1 \pm 2.8^{* * *}$ \\
\hline 5 & $-\mathrm{CH}_{2} \mathrm{OH}$ & & $4.8 \pm 0.1^{* * *}$ & $98.5 \pm 4.1$ & \multicolumn{2}{|c|}{ N.R. ${ }^{d}$} & \multicolumn{2}{|c|}{ N.R. } \\
\hline 6 & $-\mathrm{CH}_{2} \mathrm{OH}$ & & $5.8 \pm 0.1$ & $89.8 \pm 1.8$ & \multicolumn{2}{|c|}{ N.R. } & \multicolumn{2}{|c|}{ N.R. } \\
\hline 7 & $-\mathrm{CH}_{2} \mathrm{OH}$ & & $6.2 \pm 0.1$ & $83.7 \pm 4.4$ & & R. & & R. \\
\hline 9 & $-\mathrm{CH}_{2} \mathrm{OH}$ & & \multicolumn{2}{|c|}{ N.D..$^{e}$} & \multicolumn{2}{|c|}{ N.R. } & \multicolumn{2}{|c|}{ N.R. } \\
\hline 16 & -CONHEt & & $5.4 \pm 0.0^{* * *}$ & $104.4 \pm 1.3$ & \multicolumn{2}{|c|}{ N.R. } & \multicolumn{2}{|c|}{ N.R. } \\
\hline 17 & -CONHEt & & $4.0 \pm 0.1^{* * *}$ & $100 \pm 23.7$ & \multicolumn{2}{|c|}{ N.R. } & \multicolumn{2}{|c|}{ N.R. } \\
\hline 18 & -CONHEt & & $4.8 \pm 0.0^{* * *}$ & $107.7 \pm 3.0$ & \multicolumn{2}{|c|}{ N.R. } & \multicolumn{2}{|c|}{ N.R. } \\
\hline 19 & -CONHEt & & \multicolumn{2}{|c|}{ N.D. } & \multicolumn{2}{|c|}{ N.R. } & \multicolumn{2}{|c|}{ N.R. } \\
\hline 20 & -CONHEt & & $6.0 \pm 0.1$ & $99.3 \pm 0.3$ & $4.8 \pm 0.3^{*}$ & $115.0 \pm 13.0$ & $3.9 \pm 0.3$ & $32.2 \pm 11.4^{* * *}$ \\
\hline 21 & -CONHEt & & $6.5 \pm 0.1^{* *}$ & $99.0 \pm 2.8$ & $5.24 \pm 0.3$ & $77.7 \pm 4.6$ & $3.48 \pm 0.3^{*}$ & $49.2 \pm 0.4^{* * *}$ \\
\hline 24 & -CONHEt & & \multicolumn{2}{|c|}{ N.R. } & \multicolumn{2}{|c|}{ N.R. } & \multicolumn{2}{|c|}{ N.R. } \\
\hline 25 & -CONHEt & & \multicolumn{2}{|c|}{ N.R. } & \multicolumn{2}{|c|}{ N.R. } & \multicolumn{2}{|c|}{ N.R. } \\
\hline
\end{tabular}




\begin{tabular}{|c|c|c|c|}
\hline 34 & N.R. & N.D. & N.R. \\
\hline 35 & N.R. & N.R. & N.R. \\
\hline 36 & N.R. & N.R. & N.R. \\
\hline 37 & N.R. & N.R. & N.R. \\
\hline
\end{tabular}

Values are the mean \pm SEM from 5-8 independent repeats.

${ }^{a} \mathrm{~A}_{1} \mathrm{R}$ and $\mathrm{A}_{2} \mathrm{R}$ receptors in GPA1/G $\alpha_{\mathrm{il}}$ and $\mathrm{GPA} 1 / \mathrm{G} \alpha_{\mathrm{s}}$ yeast transplants, respectively.

${ }^{b}$ Negative logarithm of the agonist concentration required to induce a half-maximal response.

${ }^{c}$ The maximal response to a ligand expressed as a percentage of that obtained for NECA.

${ }^{d}$ N.R., no response.

${ }^{e}$ N.D., not determined. Full dose-response curve was not feasible.

Statistical significance compared to NECA $(*, p<0.05, * *, p<0.01, * * *, p<0.001)$ was determined by one-way ANOVA with Dunnett's post-test. 
Table 2. Ligand Affinity $\left(\mathrm{pK}_{\mathrm{A}}\right)$ and Efficacy $(\log \tau)$ of Reference Compounds and Synthetic Adenosine Derivatives at $A_{1} R, A_{2 A} R$ and $A_{2 B} R$ expressed in Yeast ${ }^{a}$

\begin{tabular}{|c|c|c|c|c|c|c|}
\hline \multirow[b]{2}{*}{ Compd } & \multicolumn{2}{|c|}{$\mathbf{A}_{1} \mathbf{R}$} & \multicolumn{2}{|c|}{$\mathbf{A}_{2 \mathrm{~A}} \mathbf{R}$} & \multicolumn{2}{|c|}{$\mathbf{A}_{2 B} \mathbf{R}$} \\
\hline & $\mathbf{p} K_{\mathbf{A}}^{b}$ & $\log \tau^{c}$ & $\mathbf{p} K_{\mathrm{A}}^{b}$ & $\log \tau^{c}$ & $\mathrm{p} K_{\mathrm{A}}^{b}$ & $\log \tau^{c}$ \\
\hline NECA & $4.4 \pm 0.1$ & $1.5 \pm 0.1$ & $5.9 \pm 0.2$ & $0.5 \pm 0.1$ & $4.2 \pm 0.1$ & $0.6 \pm 0.1$ \\
\hline Adenosine & $4.6 \pm 0.2$ & $0.9 \pm 0.1$ & $5.6 \pm 0.2$ & $0.0 \pm 0.3$ & $3.8 \pm 0.1$ & $0.3 \pm 0.1$ \\
\hline CCPA & $6.1 \pm 0.1$ & $0.6 \pm 0.1$ & $4.7 \pm 0.3$ & $-0.1 \pm 0.1$ & $4.4 \pm 0.1$ & $3.5 \pm 0.1^{* * * *}$ \\
\hline CGS-21680 & $2.1 \pm 0.9^{*}$ & $1.1 \pm 0.9$ & $4.9 \pm 0.1$ & $-0.3 \pm 0.0$ & $3.4 \pm 0.1$ & $-0.2 \pm 0.0$ \\
\hline 5 & $3.0 \pm 1.1$ & $1.8 \pm 1.1$ & \multicolumn{2}{|c|}{ N.R..$^{d}$} & \multicolumn{2}{|c|}{ N.R. } \\
\hline 6 & $4.9 \pm 0.1$ & $0.5 \pm 0.1$ & \multicolumn{2}{|c|}{ N.R. } & \multicolumn{2}{|c|}{ N.R. } \\
\hline 7 & $5.5 \pm 0.1$ & $0.7 \pm 0.1$ & \multicolumn{2}{|c|}{ N.R. } & \multicolumn{2}{|c|}{ N.R. } \\
\hline 9 & \multicolumn{2}{|c|}{ N.R. } & \multicolumn{2}{|c|}{ N.R. } & \multicolumn{2}{|c|}{ N.R. } \\
\hline 16 & $4.2 \pm 0.3$ & $1.2 \pm 0.3$ & \multicolumn{2}{|c|}{ N.R. } & \multicolumn{2}{|c|}{ N.R. } \\
\hline 17 & $3.5 \pm 0.1$ & $1.0 \pm 0.1$ & \multicolumn{2}{|c|}{ N.R. } & \multicolumn{2}{|c|}{ N.R. } \\
\hline 18 & $2.4 \pm 0.1^{*}$ & $2.4 \pm 0.0$ & \multicolumn{2}{|c|}{ N.R. } & \multicolumn{2}{|c|}{ N.R. } \\
\hline 19 & \multicolumn{2}{|c|}{ N.R. } & \multicolumn{2}{|c|}{ N.R. } & \multicolumn{2}{|c|}{ N.R. } \\
\hline 20 & $4.3 \pm 0.5$ & $1.6 \pm 0.5$ & $3.9 \pm 0.7^{* * *}$ & $0.5 \pm 0.5$ & $3.5 \pm 0.6$ & $0.1 \pm 0.5$ \\
\hline 21 & $4.8 \pm 0.5$ & $1.6 \pm 0.5$ & $4.6 \pm 0.4$ & $0.3 \pm 0.1$ & $4.2 \pm 0.1$ & $-0.2 \pm 0.1$ \\
\hline 24 & \multicolumn{2}{|c|}{ N.R. } & \multicolumn{2}{|c|}{ N.R. } & \multicolumn{2}{|c|}{ N.R. } \\
\hline 25 & \multicolumn{2}{|c|}{ N.R. } & \multicolumn{2}{|c|}{ N.R. } & \multicolumn{2}{|c|}{ N.R. } \\
\hline 34 & \multicolumn{2}{|c|}{ N.R. } & \multicolumn{2}{|c|}{ N.D..$^{e}$} & \multicolumn{2}{|c|}{ N.R. } \\
\hline 35 & \multicolumn{2}{|c|}{ N.R. } & \multicolumn{2}{|c|}{ N.R. } & \multicolumn{2}{|c|}{ N.R. } \\
\hline 36 & \multicolumn{2}{|c|}{ N.R. } & & & & J.R. \\
\hline 37 & & & & & & J.R. \\
\hline
\end{tabular}

Values are the mean \pm SEM from 5-8 independent repeats.

${ }^{a} \mathrm{~A}_{1} \mathrm{R}$ and $\mathrm{A}_{2} \mathrm{R}$ in $\mathrm{GPA} 1 / \mathrm{G} \alpha_{\mathrm{i} 1}$ and $\mathrm{GPA} 1 / \mathrm{G} \alpha_{\mathrm{s}}$ yeast transplants, respectively.

${ }^{b}$ Negative logarithm of the relative equilibrium disassociation constant for each compound generated through use of the operational model of agonism. ${ }^{36}$

${ }^{c}$ The coupling efficiency parameter $(\tau)$, generated by comparison to NECA.

${ }^{d}$ N.R., no response.

${ }^{e}$ N.D., not determined. Full dose-response curve was not feasible.

Statistical significance compared to NECA $(*, p<0.05, * *, p<0.01$, ***, $p<0.001)$ was determined by one-way ANOVA with Dunnett's post-test. 
We next sought to investigate the pharmacological properties of the $A_{2 A} R$ expressed in our GPA1/G $\alpha_{s}$ expressing strains. Both CGS-21680 and NECA displayed strong agonism at the $A_{2 A} R$, while adenosine and CCPA showed weak partial agonism (Figure 2B). Further, all ligands assayed display weak potency at the $\mathrm{A}_{2 \mathrm{~B}} \mathrm{R}$, (rank ligand potencies, NECA > adenosine $=\mathrm{CCPA}>>$ CGS-21680) with CGS-21680 failing to generate a maximal response at the ligand concentrations assayed. Thus, in our strains, CGS21680 would appear to be largely $\mathrm{A}_{2 \mathrm{~A}} \mathrm{R}$ selective and this is consistent with mammalian cell affinity data. $^{31,35}$

We next sought to compare the selectivity/preference that ligands may possess for each of the ARs. Expression of the ARs in yeast generates a clean, robust assay, with no competing signaling machinery, so enabling the proportioning of receptor responses to individual signaling pathways. We have previously used the methods developed by Figuero et al. ${ }^{37}$ to quantify ligand bias for receptors expressed in yeast. ${ }^{19,20}$ Here we report the adaptation of the equimolar method of $\operatorname{comparison}^{37}$ to quantify a ligands selectivity for a given receptor (see Experimental Section for more details). Since NECA is a full agonist for all three ARs expressed in yeast, it can be used as a reference ligand. By calculating the change in $\log \left(\tau / \mathrm{K}_{\mathrm{A}}\right)$, for an agonist relative to NECA, for each AR subtype we have generated a quantitative means of comparing receptor selectivity for all our agonists (Figure 2D-F). Adenosine and CCPA are $\mathrm{A}_{1}$ R-selective but also preferentially activate $A_{2 B} R$ over $A_{2 A} R$. In contrast, CGS-21680 is $A_{2} R$ subtype-selective with an overall preference for the $A_{2 A} R$.

Bulkier $N^{6}$-adamantyl agonists have previously been shown to be $\mathrm{A}_{1} \mathrm{R}$ selective with respect to binding affinity at rat receptors. ${ }^{26}$ Therefore we extended our studies to include novel AR agonists containing an adamantyl group. 5, 16-18 were derived from adenosine and NECA respectively (Schemes 1-2). These compounds appeared to be $A_{1} R$ selective full agonists compared with NECA, with no significant response detected at the $\mathrm{A}_{2 \mathrm{~A}} \mathrm{R}$ and $\mathrm{A}_{2 \mathrm{~B}} \mathrm{R}(p>0.05)$ (Figure $\left.3 \mathrm{~A}-\mathrm{C}\right)$. However, 5, 16-18 displayed reduced potency to the $A_{1} R$ compared to their precursors and cyclopentyl variants (Table 1). Furthermore, $\mathrm{p} K_{\mathrm{A}}$ values suggested this might be a consequence of reduced ligand binding affinities (Table 2). 
$\mathrm{A}_{1} \mathrm{R}$ agonists derived from adenosine with substituted cyclopentyl groups at the adenine $N^{6}$ position have been reported previously (e.g. GR79236, $N$-[(1S,2S)-(2-hydroxy)cyclopentyl]adenosine). ${ }^{38}$ We found that $N^{6}$-cyclopentyl derivatives 6, 7, 20 and 21 mainly signal through the $\mathrm{A}_{1} \mathrm{R}$, but for the latter two compounds minimal responses were also detected at $A_{2 A} R$ and $A_{2 B} R$ (Table 1, Figure 4).
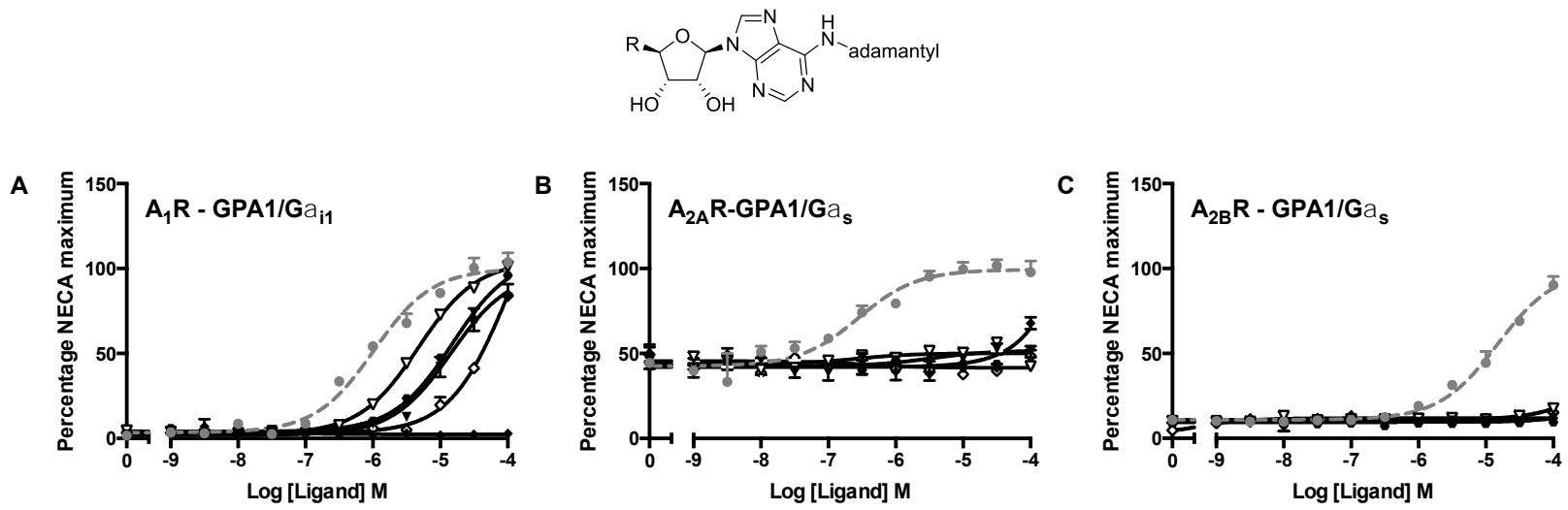

Figure 3. $N^{6}$-adamantyl derivatives selectivity at the human $A_{1} R$. Yeast strains expressing $(\mathrm{A}) \mathrm{A}_{1} \mathrm{R},(\mathrm{B})$ $\mathrm{A}_{2 \mathrm{~A}} \mathrm{R}$ and $(\mathrm{C}) \mathrm{A}_{2 \mathrm{~B}} \mathrm{R}$ were stimulated with $N^{6}$-adamantyl derivatives $(\boldsymbol{\nabla}) \mathbf{5},(\nabla) \mathbf{1 6},(\diamond) \mathbf{1 7},(\bullet) \mathbf{1 8}$ and $(\bullet)$ 34 for $16 \mathrm{~h}$ and reporter gene activity determined. Data are expressed as the percentage of the maximum response achieved when cells were stimulated with the reference agonist NECA (grey dotted line). All data are mean of 5-8 independent experiments \pm SEM.

Adenosine derivative 6 was highly $A_{1} R$ selective but failed to produce a maximal signal. In a patent in $2011^{27} \mathbf{6}$ was described as an $\mathrm{A}_{1} \mathrm{R}$-selective agonist for reducing elevated intraocular pressure in the treatment of glaucoma or ocular hypertension and this compound was assessed for selectivity with respect to binding affinity $\left(K_{\mathrm{i}}\right)$ at human subtypes $\mathrm{A}_{1}, \mathrm{~A}_{2 \mathrm{~A}}$ and $\mathrm{A}_{3} \cdot{ }^{27}$ In accordance with our results it was shown, using a radioligand displacement assay, that 6 binds with greater than 250 -fold affinity at the $A_{1}$ over the $\mathrm{A}_{2 \mathrm{~A}}$ subtype. In the yeast-based assays the novel NECA analogues $\mathbf{2 0}$ and $\mathbf{2 1}$ have equal or higher potency, respectively, than the parent compound NECA at the $\mathrm{A}_{1} \mathrm{R}$. However, in contrast to the $N^{6}$-cyclopentyl adenosine derivatives $\mathbf{6}$ and 7, $N^{6}$-cyclopentyl NECA derivatives $\mathbf{2 0}$ and $\mathbf{2 1}$ are non-selective and signal 
through the $A_{1} R, A_{2 A} R$ and $A_{2 B} R$ (Table 1). Calculation of selectivity factors confirm that 21 preferentially signals $A_{1} R>A_{2 B} R>A_{2 A} R$.

As described above, the $N^{6}$-adamantyl derivatives only induced a detectable response in $\mathrm{A}_{1} \mathrm{R}$ expressing yeast strains, suggesting that bulky $N^{6}$-substituents promote total $A_{1} R / A_{2} R$ selectivity. To explore this further we created a series of ligands containing an $N^{6}$-azabicyclo (granatane) moiety. Compounds 9, 19, 24 and 25 were screened for activity; however, no significant response was detected for these compounds via the $A_{1} R, A_{2 A} R$ or $A_{2 B} R(p>0.05$, one-way ANOVA). Some minimal response was observed for 9 and 19 at very high concentration $(100 \mu \mathrm{M})$ but it was not feasible to generate full doseresponse curves (Table 1).

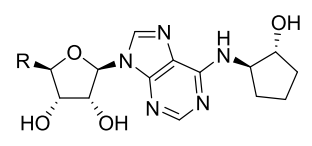

A

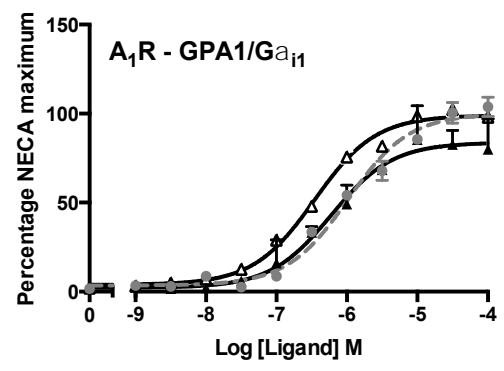

D

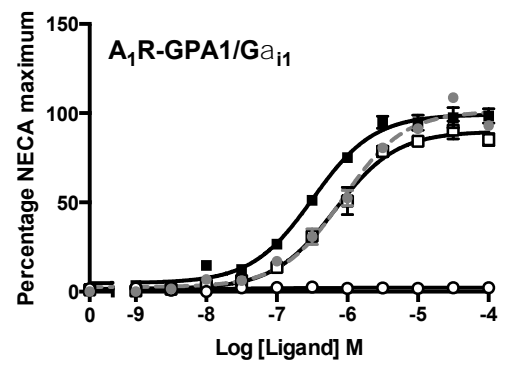

B
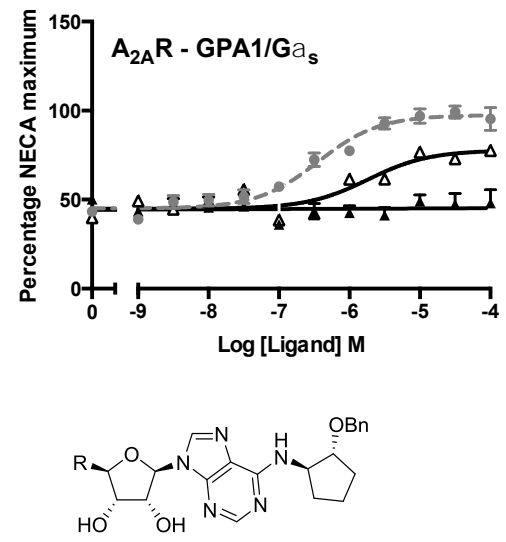

E

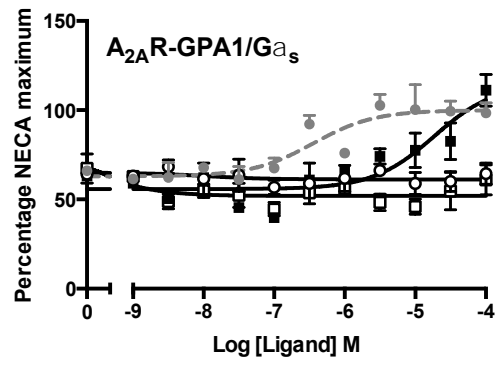

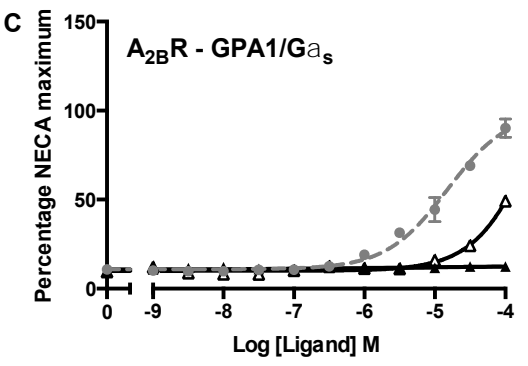

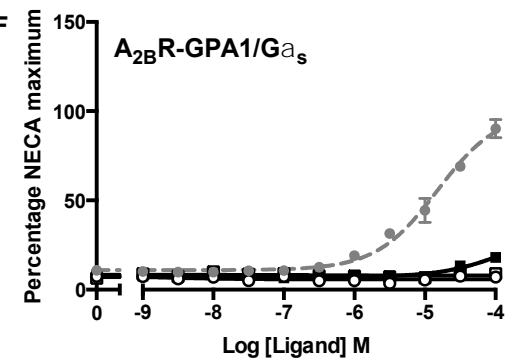

Figure 4. $N^{6}$-(2-Hydroxy)cyclopentyl derivatives of both adenosine and NECA display bias towards the $\mathrm{A}_{1}$ receptor. Yeast strains expressing the $A_{1} R(A$ and $D)$, the $A_{2 A} R\left(B\right.$ and $E$ ) and the $A_{2 B} R(C$ and $F$ ) were stimulated for $16 \mathrm{~h}$ with $N^{6}$-(2-hydroxy)cyclopentyl derivatives (A) 7 and $(\triangle) \mathbf{2 1}$ or $N^{6}$-(2- 
benzyloxy)cyclopentyl derivatives ( $\square$ ) 6, (ロ) 20 and (०) 36 and assayed for activation of the FUS1>lacZ reporter gene. Data are expressed as the percentage of the maximum response achieved when cells were stimulated with the reference agonist NECA (grey dotted line). Data are mean of at least five independent experiments \pm SEM

Replacement of the 5'-ethyl carboxamide or 5'-hydroxy group with a 2-fluorothiophenyl moiety, as in adenosine analogues $\mathbf{3 4 - 3 7}$, resulted in compounds that failed to produce any detectable response in the $A_{1} R, A_{2 A} R$ and $A_{2 B} R$ strains (Table 1). In fact, 34 was only able to activate the $A_{2 A} R$ but at concentrations of greater than $100 \mu \mathrm{M}$. These results were somewhat surprising since the $N^{6}$ hydroxycyclopentyl congener 37 (CVT-3619, later named GS 9667) has previously been described as a selective, partial agonist of the $\mathrm{A}_{1} \mathrm{R}$, with reported $K_{\mathrm{i}}$ values of $113 \mathrm{nM}$ and $1.1 \mu \mathrm{M}$ when challenged with the antagonist $\left[{ }^{3} \mathrm{H}\right] \mathrm{CPX}$, binding in $\mathrm{hA}_{1} \mathrm{R}$-expressing $\mathrm{DDT}_{1} \mathrm{MF}-2$ and $\mathrm{CHO}$ cells, respectively. ${ }^{14}$ To determine if the lack of functional activity for $\mathbf{3 4 ,} \mathbf{3 6}$ and $\mathbf{3 7}$ in our yeast assays resulted from the compounds failing to cross the membrane, we performed a competition assay between $\mathbf{3 4 ,} 36$ and $\mathbf{3 7}$ and either NECA, adenosine or CCPA at the $A_{1} R$ (Supplementary Figure S2).

In line with the previously reported data, ${ }^{14}$ we confirmed $\mathbf{3 7}$ does appear to compete with all three ligands at the $\mathrm{A}_{1} \mathrm{R}\left(\mathrm{pA}_{2}=5.3 \pm 0.4\right)$. Interestingly, despite the fact that 37 interacts with the $\mathrm{A}_{1} \mathrm{R}$, in our experimental system, it appears unable to induce a measurable response. It is worth noting that, $\mathrm{A}_{1} \mathrm{R}$ agonist activity of 37 (CVT-3619) was previously demonstrated in rat adipocytes where it reduced cAMP content and consequently lipolysis ${ }^{14}$ although it is entirely possible that the observed response in these cell lines resulted from "off-target activation" of other receptors. Despite entering clinical trials where it was evaluated for its efficacy to lower lipids and thus improve glycemia, CVT-3619 (37) showed inadequate pharmacokinetics and it was discontinued. ${ }^{39}$ Furthermore, some recent studies suggest that the $\mathrm{A}_{1} \mathrm{R}$ may not play a significant role in hepatic regulation of lipid metabolism. ${ }^{40}$ Similar to $\mathbf{3 7}$, close analog $\mathbf{3 6}$ also 
acted as a competitive antagonist at $\mathrm{A}_{1} \mathrm{R}\left(\mathrm{pA}_{2}=6.4 \pm 0.2\right.$, Supplementary Figure S2) but 34 did not appear to bind to the $\mathrm{A}_{1} \mathrm{R}$ at all.

Determining $A_{1} R$ versus $A_{3} R$ Selectivity in Mammalian Cells. Traditionally, many compounds that display selectivity for the $A_{1} R$ compared to the $A_{2} R$ s frequently also display activity to the $A_{3} R$. However, as described previously, we were unable to obtain functional coupling of the $\mathrm{A}_{3} \mathrm{R}$ to the yeast pheromoneresponse pathway (Supplementary Figure S1). Thus, to provide a complete characterization of the $A_{1} R$ selective compounds isolated in the yeast screen, we utilized mammalian CHO-K1 cells transiently transfected with either the $\mathrm{A}_{1} \mathrm{R}$ or the $\mathrm{A}_{3} \mathrm{R}$. CHO-K1 are an established cell line frequently used to assay the activity of adenosine receptors. ${ }^{41,42}$ Both the $A_{1} R$ and the $A_{3} R$ couple to the inhibitory $G$ protein family $\left(\mathrm{G} \alpha_{\mathrm{i}}\right)$ thereby reducing the cellular concentration of cAMP.

Using CHO- $\mathrm{A}_{1} \mathrm{R}$ cells $\left(\mathrm{CHO}-\mathrm{K} 1\right.$ cells expressing the $\left.\mathrm{A}_{1} \mathrm{R}\right)$ we first confirmed that NECA, adenosine and CCPA were able to inhibit forskolin-stimulated cAMP production (Figure 5A) generating pIC $_{50}$ values (Table 3 ) equivalent to those previously reported. ${ }^{41,42}$ Further, all compounds $(\mathbf{5}, \mathbf{6}, \mathbf{7}, \mathbf{1 6}, \mathbf{1 7}$, 18, 20 and 21) identified in the yeast as eliciting a functional $A_{1} R$ response displayed full agonist activity against the $A_{1} R$ in the mammalian cells, but with varying potencies (Figure $5 B$, Table 3 ). Significantly, when these compounds were assayed against the CHO-A ${ }_{3} \mathrm{R}$ cells (Figure 5C and 5D, Table 3) only 7, 17, 20 and 21 were able to inhibit forskolin-stimulated cAMP production. Thus, taken together these data suggest that, at concentrations $\leq 1 \mu \mathrm{M}, \mathbf{5}, \mathbf{6}, \mathbf{1 6}$ and $\mathbf{1 8}$ display $\mathrm{A}_{1} \mathrm{R}$-selectivity. Intriguingly, 2-adamantyl derivative $\mathbf{1 8}$ is almost as potent an agonist of $A_{1} R$ as NECA but completely $A_{1} R$-selective. 
Table 3. Potency $\left(\mathrm{pIC}_{50}\right)$ and response range of reference ligands and putative $\mathrm{A}_{1} \mathrm{R}$ selective compounds at the $A_{1} R$ and $A_{3} R$ as measured in transfected $\mathrm{CHO}-\mathrm{K} 1$ cells.

\begin{tabular}{|c|c|c|c|c|c|c|}
\hline \multirow{3}{*}{ Compd } & \multicolumn{3}{|c|}{$\mathbf{A}_{1} \mathbf{R}$} & \multicolumn{3}{|c|}{$\mathbf{A}_{3} \mathbf{R}$} \\
\hline & $\mathrm{pIC}_{50}{ }^{a}$ & Response & $\mathbf{n}$ & $\mathrm{pIC}_{50}{ }^{a}$ & Response & $\mathbf{n}$ \\
\hline & & Range $^{b}$ & & & Range $^{b}$ & \\
\hline NECA & $9.68 \pm 0.16$ & $-73.4 \pm 5.8$ & 6 & $9.31 \pm 0.17$ & $-44.1 \pm 3.0$ & 8 \\
\hline Adenosine & $8.63 \pm 0.11^{*}$ & $-66.4 \pm 3.7$ & 6 & $8.94 \pm 0.14$ & $-38.7 \pm 2.4$ & 5 \\
\hline CCPA & $9.30 \pm 0.15$ & $-71.4 \pm 4.3$ & 6 & $7.95 \pm 0.13^{* *}$ & $-46.6 \pm 4.8$ & 8 \\
\hline 5 & $7.72 \pm 0.20^{* *}$ & $-61.0 \pm 6.1$ & 5 & N.R & N.R & 8 \\
\hline 6 & $9.17 \pm 0.15$ & $-55.28 \pm 3.6$ & 4 & N.R. & N.R. & 6 \\
\hline 7 & $8.36 \pm 0.17^{*}$ & $-60.0 \pm 4.4^{*}$ & 6 & $7.56 \pm 0.11^{* *}$ & $-35.1 \pm 2.2$ & 5 \\
\hline 16 & $8.54 \pm 0.3^{*}$ & $-52.15 \pm 6.0^{*}$ & 6 & N.R & N.R. & 6 \\
\hline 17 & $7.43 \pm 0.19$ & $-39.3 \pm 3.9^{* *}$ & 4 & $7.1 \pm 0.12^{* *}$ & $-32.7 \pm 2.2^{*}$ & 6 \\
\hline 18 & $9.40 \pm 0.34$ & $-51.07 \pm 7.9$ & 6 & N.R & N.R & 6 \\
\hline 20 & $10.53 \pm 0.28^{*}$ & $-48.35 \pm 5.6^{*}$ & 4 & $6.57 \pm 0.15^{* * *}$ & $-38.0 \pm 4.0$ & 5 \\
\hline 21 & $8.21 \pm 0.2^{*}$ & $-47.67 \pm 4.3^{*}$ & 4 & $8.64 \pm 0.08$ & $-37.9 \pm 1.2$ & 5 \\
\hline
\end{tabular}

Data are the mean \pm SEM of $n$ individual sets.

${ }^{a}$ The negative logarithm of the agonist concentration required to produce a half-maximal response.

${ }^{b}$ The response range of the agonists expressed as a percentage of total forskolin range (0-100\%).

Statistical significance compared to NECA $(*, p<0.05, * * p<0.01, * * * p<0.001)$ was determined by one-way ANOVA with Dunnett's post-test. 

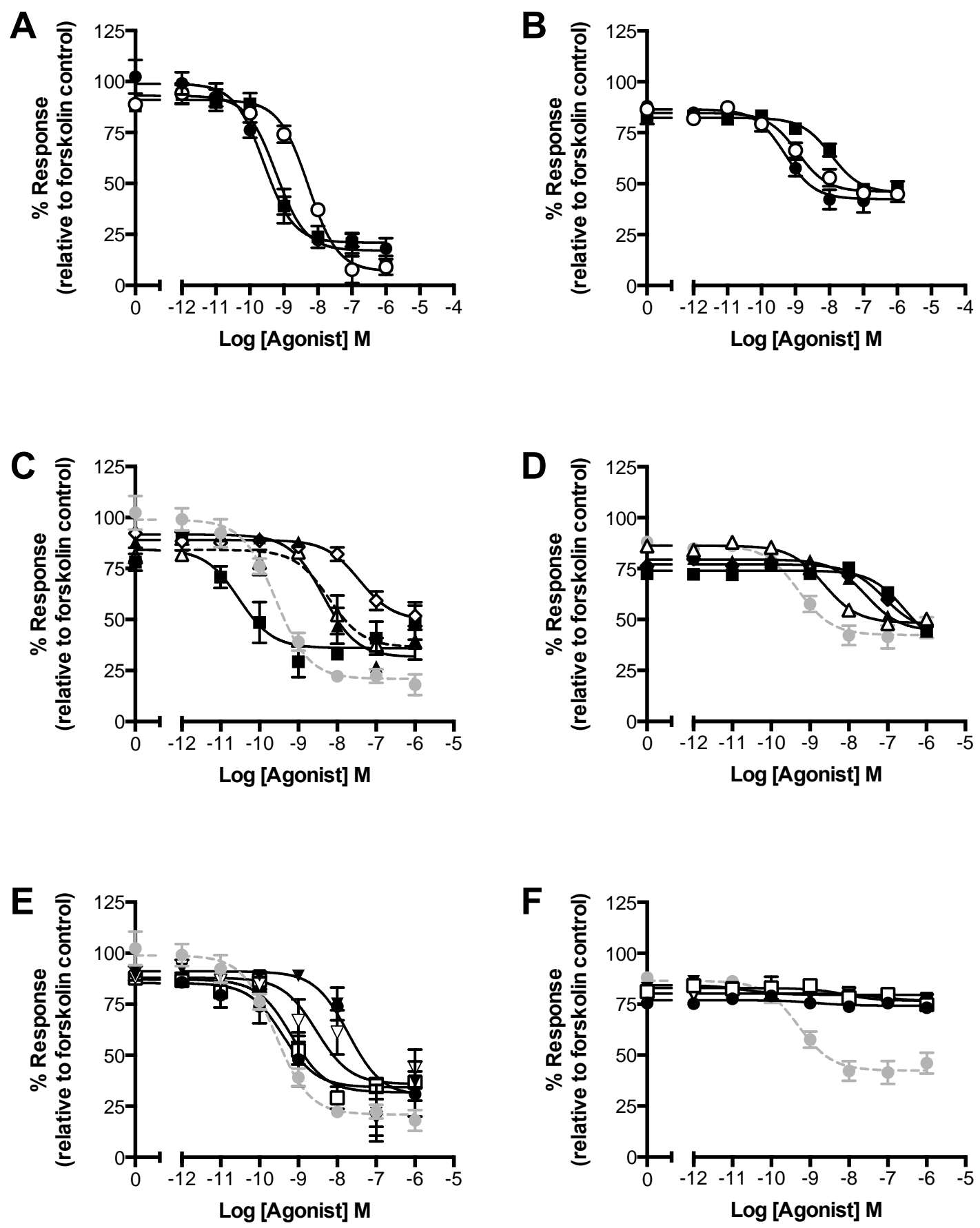

Figure 5. Determining the $A_{1} R$-selectivity of compounds isolated in the yeast screen against the $A_{1} R$ and $\mathrm{A}_{3} \mathrm{R}$ expressed in mammalian cells. $\mathrm{CHO}-\mathrm{K} 1$ cells transiently transfected with $\mathrm{A}_{1} \mathrm{R}(\mathrm{A}, \mathrm{C}$ and $\mathrm{E})$ or $\mathrm{A}_{3} \mathrm{R}$ $(\mathrm{B}, \mathrm{D}$ and F) were stimulated with $(\bullet)$ NECA, (O) adenosine, ( $\bullet$ ) CCPA (A and B) or the compounds determined to be active at the $\mathrm{A}_{1} \mathrm{R}$ from the yeast screen $(\Delta) \mathbf{7},(\diamond) \mathbf{1 7},(\mathbf{\square}) \mathbf{2 0},(\triangle) \mathbf{2 1}(\mathrm{C}$ and $\mathrm{D})(\boldsymbol{\nabla}) \mathbf{5}$, 
$(\square)$ 6, ( $\nabla)$ 16, (•) 18 (E and F). In panels (C-F) NECA dose-inhibition curve is shown as grey dashed line with grey symbols. All cells were assayed for inhibition of $10 \mu \mathrm{M}$ forskolin-stimulated cAMP. Data are expressed as the percentage of the maximum response achieved when cells were stimulated with $10 \mu \mathrm{M}$ forskolin. Data are mean of 4-8 independent repeats \pm SEM.

\section{Molecular simulation of agonist docking into the $A_{l} R$}

Based on the pharmacological experimental findings that most of our $N^{6}$-substituted 5'-Nethylcarboxamido and 5'-hydroxymethyl derivatives activated the $A_{1} R$, but all the 5'-(2-fluoro)thiophenyl derivatives failed to do so, we used a molecular modeling approach to dock all our synthetic adenosine derivatives into a homology model of the human $A_{1} R$. The recently solved crystal structure of the human $\mathrm{A}_{2 \mathrm{~A}} \mathrm{R}$ complexed with the agonist UK-432097 (PDB ID: 3QAK) ${ }^{43}$ served as the template for this homology model. We reasoned that the bound agonist UK-432097 has a large $N^{6}$-substituent (Figure 6A) as is the case for our synthetic adenosine analogues.

In order to validate the utility of this $A_{2 A} R$ crystal structure as a template for generating the $A_{1} R$ homology model we docked compounds 20,21 and 34, that also showed activity at the $A_{2 A} R$ in our assays, into the $A_{2 A} R$ crystal structure. Indeed, the proposed positions and side chain interactions for these compounds (Figure 6C and Supplementary Figure S3A and S3B) are very similar to known agonists bound to the $\mathrm{A}_{2 \mathrm{~A}} \mathrm{R}$ (Figure $6 \mathrm{~A}$ and $6 \mathrm{~B}$ ).

Furthermore, after closely inspecting the crystal structures of the adenosine-, NECA- (Figure 6B) and UK-432097-bound (Figure 6A) human $\mathrm{A}_{2 \mathrm{~A}} \mathrm{R}$ (PDB IDs: 2YDO, 2YDV and 3QAK, respectively) ${ }^{43,44}$ we would argue that hydrogen bond formation between the ligand and the homologous Thr- $91^{3.36}$, Asn$254^{6.55}$, Thr- $277^{7.42}$ and His-278 $8^{7.43}$ (superscript: Ballesteros-Weinstein numbering ${ }^{45}$ ) in the $\mathrm{A}_{1} \mathrm{R}$ is important to stabilize the active conformation of the receptor. ${ }^{43,44}$ These residues are highly conserved across the AR family. Taking this into consideration (details see Experimental Section) the docking yielded ligand 
orientations for 5-7, 16-18, 20 and 21 (Figure 6D and Supplementary Figure S3C-I) that closely resemble the orientations of UK-432097- and NECA-bound to the human $\mathrm{A}_{2 \mathrm{~A}} \mathrm{R}$ (Figure 6A and 6B). In this distinct position the ribose moiety binds deeply into the binding pocket potentially forming hydrogen bonds with Thr-91 $1^{3.36}$, Asn- $184^{5.42}$, Thr- $277^{7.42}$ and His- $278^{7.43}$. The purine ring $\pi$-stacks against Phe- $171^{\text {ECL2 }}$ and can form hydrogen bonds with Asn-254.55, whereas the bulky $N^{6}$-substitutes are located near the exit of the binding pocket. We found experimentally that all these compounds were agonists at the $A_{1} R$ in our yeastbased functional assay. Intriguingly, $\mathbf{6}$ and $\mathbf{2 0}$ were docked before they were tested, and based on our model, predicted to be active agonists, which indeed was the case.

The predicted binding positions for granatane derivatives $\mathbf{9}$ and $\mathbf{1 9}$ are somewhat similar, however, the purine ring is further away from Asn- $254^{6.55}$ so that no hydrogen bonds are suggested (Figure 6E and Supplementary Figure S3J). At very high concentration, $\mathbf{9}$ and $\mathbf{1 9}$ were able to partially activate the $A_{1} R$, but it was experimentally not possible to obtain full dose response curves.

Docking of both inactive compounds $\mathbf{2 4}$ and $\mathbf{3 4}$ yielded binding positions where the purine ring adopts a syn-conformation with respect to the ribose (Figure 6F and Supplementary Figure S3K). It is also noticeable that $\mathbf{2 4}$ is not in close contact with $\operatorname{Trp}-247^{6.48}$, a residue which is highly conserved across the AR family and in a recent molecular dynamics simulation was shown to act as a conformational toggle switch in the receptor activation mechanism. ${ }^{46}$ The docking simulations with adenosine derivatives $\mathbf{2 5}, \mathbf{3 5}$ 37, all of which failed to activate the $A_{1} R$, did not return any binding positions for our model. 

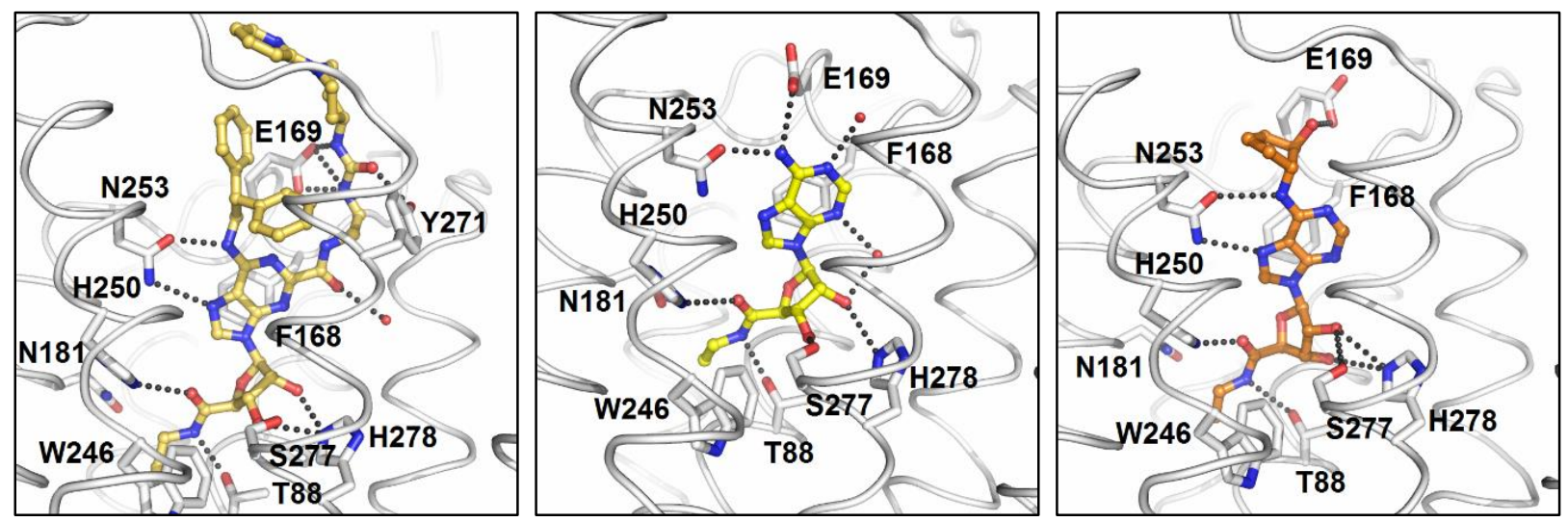

D

E

$\mathbf{F}$
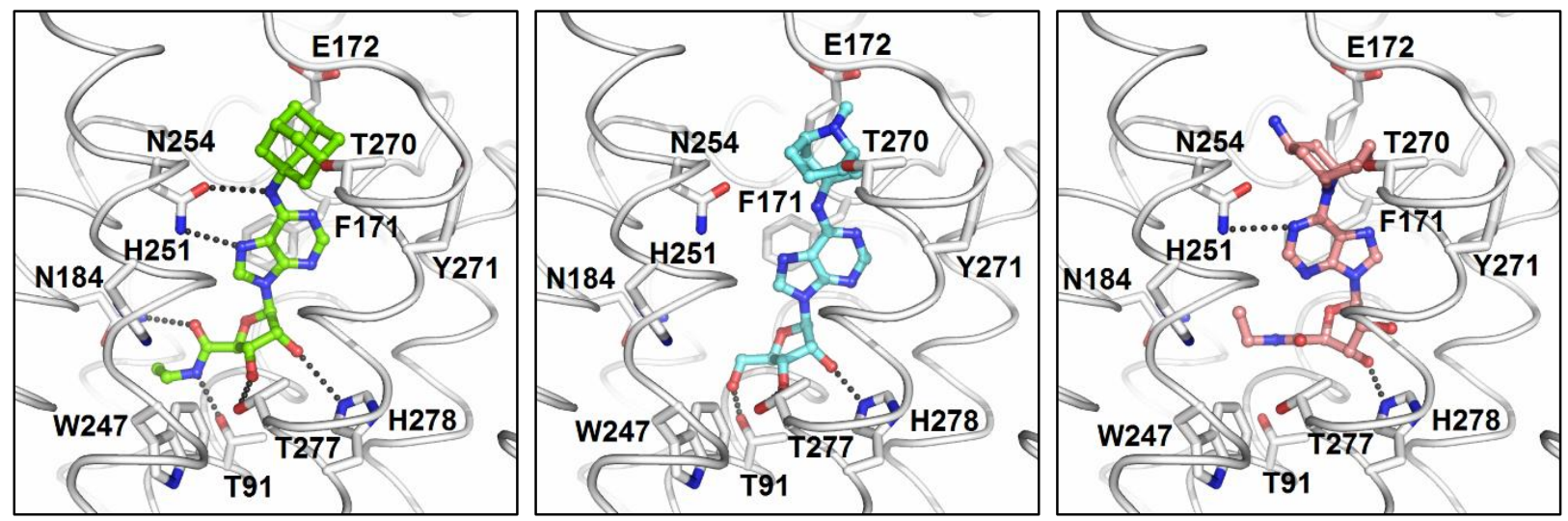

Figure 6. Docking of $N^{6}$-substituted adenosine derivatives into an $\mathrm{A}_{1} \mathrm{R}$ homology model. (A) Crystal structures of human $\mathrm{A}_{2 \mathrm{~A}} \mathrm{R}$ bound with agonist UK-432097 (gold, PDB ID: 3QAK) and (B) with agonist NECA (yellow, PDB ID: 2YDV) for comparison, indication key binding residues and interactions. Representative examples of proposed binding poses of $N^{6}$-substituted adenosine derivatives in the $\mathrm{A}_{2 \mathrm{~A}} \mathrm{R}$ crystal structure and in the $A_{1} R$ homology model. (C) 21 (orange) docked into $A_{2 A} R$ crystal structure. (D) 16 (light green), (E) 9 (light blue) and (F) 24 (pink) docked into $A_{1} R$ homology model. Black dotted lines represent potential hydrogen bonds. Numbering of residues in (A-C) according to P29274 $\left(h \mathrm{~A}_{2 \mathrm{~A}} \mathrm{R}\right)$ and of homologous residues in (D-F) according to P30542 ( $\left.h \mathrm{~A}_{1} \mathrm{R}\right)$. Ballesteros-Weinstein (BW) numbering: T88 $\left(\mathrm{A}_{2 \mathrm{~A}}\right)$, T91 $\left(\mathrm{A}_{1}\right)$ : BW 3.36; F168 $\left(\mathrm{A}_{2 \mathrm{~A}}\right), \mathrm{F} 171\left(\mathrm{~A}_{1}\right)$ : BW ECL2; E169 $\left(\mathrm{A}_{2 \mathrm{~A}}\right)$, E172 $\left(\mathrm{A}_{1}\right)$ : BW ECL2; N181 $\left(\mathrm{A}_{2 \mathrm{~A}}\right), \mathrm{N} 184\left(\mathrm{~A}_{1}\right)$ : BW 5.42; W246 (A $\left.\mathrm{A}_{2 \mathrm{~A}}\right), \mathrm{W} 247\left(\mathrm{~A}_{1}\right)$ : BW 6.48; H250 ( $\left.\mathrm{A}_{2 \mathrm{~A}}\right), \mathrm{H} 251\left(\mathrm{~A}_{1}\right)$ : BW 6.52; N253 
$\left(\mathrm{A}_{2 \mathrm{~A}}\right), \mathrm{N} 254\left(\mathrm{~A}_{1}\right)$ : BW 6.55; T270 $\left(\mathrm{A}_{1}\right): \mathrm{BW} 7.35 ; \mathrm{Y} 271\left(\mathrm{~A}_{2 \mathrm{~A}}\right), \mathrm{Y} 271\left(\mathrm{~A}_{1}\right): \mathrm{BW} 7.36 ; \mathrm{S} 277\left(\mathrm{~A}_{2 \mathrm{~A}}\right), \mathrm{T} 277$ $\left(\mathrm{A}_{1}\right)$ : BW 7.42; H278 $\left(\mathrm{A}_{2 \mathrm{~A}}\right), \mathrm{H} 278\left(\mathrm{~A}_{1}\right)$ : BW 7.43. For activities of docked compounds see Table 1. Proposed binding poses for the remaining compounds are shown in Figure S3 (Supporting Information).

\section{Conclusions}

Herein, we report the synthesis of a series of adenosine derivatives that were modified at the $N^{6}$ position of the purine ring and the $\mathrm{C}-5^{\prime}$ positions of the ribose moiety. These compounds were evaluated using a yeast-based and mammalian cell-based assay for quantifying their AR subtype selectivity. Our biological data show that compounds bearing a granatane azabicyclic moiety at $N^{6}$ and/or a 5 '-(2fluorothiophenyl) substituent at the ribose fail to produce responses in $A_{1} R, A_{2 A} R$ or $A_{2 B} R$ cells. Conversely, $N^{6}$-adamantyl adenosine and NECA congeners were completely $\mathrm{A}_{1} \mathrm{R}$ selective. Moreover, it emerged that $N^{6}$-(2-hydroxy)cyclopentyl and $N^{6}$-(2-benzyloxy)cyclopentyl derivatives are potent agonists, preferentially activating $A_{1} R$ over the other subtypes. It is worth noting that novel NECA derivative 20 exhibited higher potency and $A_{1} R$ selectivity than its parent compound. Further, we present an $A_{1} R$ homology model that corroborates our experimental findings. Notably, adenosine derivatives $\mathbf{5}$ and $\mathbf{6}$, and novel NECA analogs $\mathbf{1 6}$ and $\mathbf{1 8}$ are completely $\mathrm{A}_{1}$ R-selective, potent agonists. Therefore they should represent useful tool compounds in purinergic signaling research and warrants further assessment of their therapeutic potential.

\section{Experimental Section}

General Chemistry. All reactions were performed under an inert argon atmosphere. Anhydrous tetrahydrofuran (THF), toluene and dichloromethane (DCM) were obtained by filtration through a system of alumina columns under a positive pressure of argon. Anhydrous dimethylformamide (DMF) was purchased as dry over molecular sieves from Sigma-Aldrich. Solvents were evaporated under reduced 
pressure at approximately $45^{\circ} \mathrm{C}$ using a Buchi Rotavapor or under high vacuum on a schlenk line. Reagents were purchased from Sigma-Aldrich, Acros, Alfa Aesar, Fischer Scientific or Hänseler and used without further purification. Reactions were monitored by thin layer chromatography (TLC) using aluminium sheets pre-coated with silica (Macherey-Nagel ALUGRAM Xtra SII, G/UV ${ }_{254}$ ). Detection was under UV light source $\left(\lambda_{\max } 254 \mathrm{~nm}\right)$ or through staining with potassium permanganate solution (5\%), vanillin spray or ninhydrin, with subsequent heating. Flash column chromatography was carried out using silica gel from Sigma-Aldrich (pore size $60 \AA, 230-400$ mesh particle size) as the stationary phase.

Proton nuclear magnetic resonance spectra $\left({ }^{1} \mathrm{H}\right.$ NMR) were recorded using a Bruker Avance 300 or an Avance II 400 spectrometer. Chemical shifts $\left(\delta_{\mathrm{H}}\right)$ are reported in parts per million (ppm) and are referenced to the residual solvent peak. The order of citation in parentheses is (1) number of equivalent nuclei (by integration), (2) multiplicity: s (singlet), d (doublet), t (triplet), q (quartet), quint (quintet), m (multiplet) etc), (3) coupling constants $(J)$ in Hertz $(\mathrm{Hz})$ and (4) assignment. Carbon nuclear magnetic resonance spectra $\left({ }^{13} \mathrm{C}\right.$ NMR) were recorded using a Bruker Avance 300 or an Avance II 400 spectrometer. Chemical shifts are quoted in parts per million (ppm) and are referenced to the residual solvent peak. The assignment is quoted in parentheses. COSY, HSQC and DEPT were routinely used to assign peaks in ${ }^{1} \mathrm{H}$ and ${ }^{13} \mathrm{C}$ NMR spectra. Addition of $\mathrm{D}_{2} \mathrm{O}$ was used to confirm the assignment of $\mathrm{OH}$ and $\mathrm{NH}$ peaks. Mass spectra and high resolution mass spectra (HRMS) were recorded on a ThermoScientific LTQ Orbitrap XL spectrometer consisting of a linear ion trap (LTQ) featuring a HCD collision cell, coupled to the Orbitrap mass analyzer, equipped with a nanoelectrospray ion source (NSI). MS and HRMS spectra were determined by the Mass Spectrometry Group at the Department of Chemistry and Biochemistry, University of Bern (PD Dr. S. Schürch).

The purity of the compounds was determined with UPLC-MS on a Dionex Ultimate 3000 using a reversed-phase column Dionex Acclain RSLC, 120C18, 3 x 50 mm, $2.2 \mu \mathrm{m}, 120 \AA$ pore size, flow 1.2 $\mathrm{mL} / \mathrm{min}$. The gradient used was $100 \% \mathrm{~A}$ to $100 \% \mathrm{D}$ over $7 \mathrm{~min}$, with A (water with $0.1 \%$ TFA) and D (10\% 
$\mathrm{H}_{2} \mathrm{O} / 90 \%$ ACN+0.1\% TFA). Purity was determined by total absorbance at $254 \mathrm{~nm}$. All tested compounds were $\geq 95 \%$ pure, except 17 which was $94 \%$ pure.

Established Adenosine Agonists. 5'-N-ethylcarboxamidoadenosine (NECA), 2-chloro- $N^{6}$ cyclopentyladenosine (CCPA), CGS-21680, 8-cyclopentyl-1,3-dipropylxanthine (DPCPX) and SLV-320 were purchased from R \& D Systems (Bristol, UK). Where possible, compounds were prepared as 10mM stocks in DMSO.

Chemical Synthesis. Intermediates $\mathbf{2},{ }^{29} \mathbf{1 0},{ }^{32} \mathbf{2 6},{ }^{32}$ and $\mathbf{2 7}^{34}$ were synthesised as described in the literature with only slight experimental modifications. (3-endo)-9-Methyl-9-azabicyclo[3.3.1]nonan-3amine was synthesised as described previously by our group. ${ }^{30}$ tert-Butyl-9-azabicyclo[3.3.1]nonan-3ylcarbamate (22) was synthesised as described previously. ${ }^{33}$ Intermediate $\mathbf{2 9}^{47}$ is known but was obtained with different methodology. Intermediate $\mathbf{2 8}$ is a novel compound. Further details on the synthesis and characterisation of these intermediates are available in the Supporting Information. 3-Amino-1adamantanol and $(1 R, 2 R)$-2-aminocyclopentanol hydrochloride were prepared as described in the Supporting Information.

General Procedure A for the Synthesis of Intermediates 3, 4, 8, 11-15, 23, 30-33. The appropriate chloride was dissolved in ethanol $(20 \mathrm{~mL} / \mathrm{mmol})$. The amine and trimethylamine or DIPEA were then added and the reaction mixture was refluxed until TLC analysis indicated completion. The solvent was removed in vacuo and the resultant material was purified with column chromatography. The choice of base did not appear to have an effect on the yield or reaction time. In the case of compounds $\mathbf{4 , 8}$, 13-15 and 31-33 the reaction was complete after $18 \mathrm{~h}$, whereas sterically hindered $\mathbf{3}, \mathbf{1 1}, \mathbf{1 2}, \mathbf{2 3}$ and 30 required 5 days refluxing at $120{ }^{\circ} \mathrm{C}$ to obtain sufficient amounts of product. In cases where the amine is a hydrochloride salt this was first stirred for 20 min with the base, before addition of the appropriate chloride in ethanol. For specific purification conditions see individual compounds. 
General Procedure B for the Synthesis of Compounds 16-20, 24, 34-37. Acetonide protected compounds 11-15, 23 or 30-33 were dissolved in water and acetic acid and stirred at $80{ }^{\circ} \mathrm{C}$ overnight. The water was removed in vacuo and the resultant crude material was purified with column chromatography.

General Procedure C for the Synthesis of Compounds 7 and 21. Benzyl protected compounds 4 and 20 were dissolved in ethanol $(8 \mathrm{~mL} / \mathrm{mmol})$. Cyclohexene and $\mathrm{Pd}(\mathrm{OH})_{2} / \mathrm{C}$ were added and refluxed at $100{ }^{\circ} \mathrm{C}$ until TLC indicated completion. The reaction mixture was allowed to cool to room temperature and filtered through celite. The crude material was purified with column chromatography.

General Procedure D for the Synthesis of Compounds 5, 6 and 9. Acetyl protected compounds 3, 4 and 8 were dissolved in methanol $(20 \mathrm{~mL} / \mathrm{mmol})$. Potassium carbonate was added and stirred vigorously for $3 \mathrm{~h}$. The solvent was removed in vacuo and the crude material was purified with column chromatography.

6- $\boldsymbol{N}$-(1-Adamantyl)-5'-O-acetyladenosine (3). 3 was synthesised according to the general procedure A, using chloride $2(0.2 \mathrm{~g}, 0.48 \mathrm{mmol})$, amantadine hydrochloride $(0.14 \mathrm{~g}, 0.72 \mathrm{mmol})$ and DIPEA (0.84 mL, $4.80 \mathrm{mmol})$. After purification with column chromatography (methanol/DCM, 2-6\%) monoacetylated 3 was obtained as a white solid as the major product ( $0.13 \mathrm{~g}, 62 \%$ yield). ${ }^{1} \mathrm{H}$ NMR (300 MHz, DMSO- $\left.d_{6}\right) \delta 8.31(1 \mathrm{H}, \mathrm{s}$, adenine $\mathrm{H}), 8.22(1 \mathrm{H}, \mathrm{s}$, adenine $\mathrm{H}), 6.61(1 \mathrm{H}, \mathrm{s}, \mathrm{NH}), 5.89(1 \mathrm{H}, \mathrm{d}, J 5.1$, 1'-H), 5.56 (1H, d, J 5.7, 2'-OH), 5.37 (1H, d, J 5.4, 3'-OH), 4.67 (1H, dd, J 10.5, 5.2, 2'-H), 4.32 (1H, dd, $\left.J 11.8,3.7,5^{\prime}-\mathrm{H} H\right), 4.26$ (1H, dd, $\left.J 10.5,5.4,3^{\prime}-\mathrm{H}\right), 4.16$ (1H, dd, $\left.J 11.8,6.1,5^{\prime}-H \mathrm{H}\right), 4.07$ (1H, m, 4'-H), $2.21\left(6 \mathrm{H}, \mathrm{m}, 6 \mathrm{x}\right.$ adamantyl H), $2.08\left(3 \mathrm{H}, \mathrm{m}, 3 \mathrm{x}\right.$ adamantyl H), $2.00\left(3 \mathrm{H}, \mathrm{s}, \mathrm{CH}_{3}\right), 1.68(6 \mathrm{H}, \mathrm{m}, 6 \mathrm{x}$ adamantyl H); ${ }^{13} \mathrm{C}$ NMR (100 MHz, DMSO- $\left.d_{6}\right) \delta 170.1,154.4,151.9,148.4,139.5,119.9,87.9,81.5,72.8$, 70.3, 63.9, 52.1, 41.0, 36.0, 29.0, 20.6; HRMS $\left(\mathrm{ESI}^{+}\right) \mathrm{m} / z$ calcd for $\mathrm{C}_{22} \mathrm{H}_{30} \mathrm{~N}_{5} \mathrm{O}_{5}[\mathrm{MH}]^{+}$444.2241, found 444.2229; purity UPLC-MS 99\%, retention time $=2.92 \mathrm{~min}$.

6- $N$-((1R,2R)-2-(Benzyloxy)cyclopentyl)-5'-O $O$-acetyladenosine (4). 4 was synthesised according to the general procedure A, using chloride $\mathbf{2}(0.20 \mathrm{~g}, \quad 0.48 \mathrm{mmol}), \quad(1 R, 2 R)$-1-amino-2- 
benzyloxycyclopentane $(0.13 \mathrm{~mL}, 0.72 \mathrm{mmol})$ and triethylamine $(0.19 \mathrm{~mL}, 1.34 \mathrm{mmol})$. After purification with column chromatography (methanol/DCM, 1-4\%) monoacetylated product 4 was obtained as a pale yellow solid as the major product $(0.12 \mathrm{~g}, 52 \%$ yield $) .{ }^{1} \mathrm{H}$ NMR $\left(300 \mathrm{MHz}, \mathrm{DMSO}-d_{6}\right) \delta 8.34(1 \mathrm{H}$, s, adenine H), $8.25(1 \mathrm{H}$, br s, adenine H), $7.90(1 \mathrm{H}, \mathrm{m}, \mathrm{NH}), 7.33-7.18(5 \mathrm{H}, \mathrm{m}, 5 \mathrm{x}$ phenyl H), $5.93(1 \mathrm{H}, \mathrm{d}, J$ 5.1, 1'H), $5.57\left(1 \mathrm{H}, \mathrm{d}, J 5.7,2^{\prime}-\mathrm{OH}\right), 5.37\left(1 \mathrm{H}, \mathrm{d}, J 5.3,3^{\prime}-\mathrm{OH}\right), 4.68\left(1 \mathrm{H}, \mathrm{dd}, J 10.4,5.1,2^{\prime}-\mathrm{H}\right), 4.63-4.51(3 \mathrm{H}$, m, $C H_{2} \mathrm{Ph}$ and 1-H), $4.33\left(1 \mathrm{H}, \mathrm{dd}, J 11.8,3.6,5^{\prime}-H \mathrm{H}\right), 4.27\left(1 \mathrm{H}, \mathrm{dd}, J 10.4,5.3,3^{\prime}-\mathrm{H}\right), 4.18(1 \mathrm{H}, \mathrm{dd}, J 11.8$, 6.2, 5'-HH), 4.09 (1H, m, 4'-H), 4.01 (1H, m, 2-H), 2.13-1.90 (5H, m, 2 x cyclopentyl $\mathrm{H}$ and $\left.\mathrm{CH}_{3}\right), 1.80-$ $1.55\left(4 \mathrm{H}, \mathrm{m}, 4 \mathrm{x}\right.$ cyclopentyl H); ${ }^{13} \mathrm{C}$ NMR $\left(100 \mathrm{MHz}, \mathrm{DMSO}-d_{6}\right) \delta 170.1,154.2,152.5,139.4,138.9$, 128.1, 127.3, 127.1, 114.5, 87.8, 84.1, 81.5, 72.9, 70.3, 70.1, 63.9, 56.4, 30.2, 21.4, 20.6; HRMS (ESI) calcd for $\mathrm{C}_{24} \mathrm{H}_{30} \mathrm{O}_{5} \mathrm{~N}_{6}[\mathrm{MH}]^{+}$484.2191, found 484.2172; purity UPLC-MS 99\%, retention time $=2.55$ min.

6- $N$-(1-Adamantyl)adenosine (5). ${ }^{48} 5$ was synthesised according to the general procedure $\mathrm{D}$, using $3(0.03 \mathrm{~g}, 0.06 \mathrm{mmol})$ and potassium carbonate $(0.005 \mathrm{~g}, 0.04 \mathrm{mmol})$. After purification with column chromatography (methanol/DCM, 4\%) product 5 was obtained as a white solid (0.03 g, 99\% yield). ${ }^{1} \mathrm{H}$ NMR (300 MHz, DMSO-d $\left.d_{6}\right) \delta 8.35(1 \mathrm{H}, \mathrm{s}$, adenine H), $8.21(1 \mathrm{H}, \mathrm{s}$, adenine $\mathrm{H}), 6.65(1 \mathrm{H}, \mathrm{s}, \mathrm{NH}), 5.87(1 \mathrm{H}$, d, J 6.1, 1'-H), 5.44 (1H, d, J 6.1, 2'-OH), 5.37 (1H, dd, J 7.1, 4.6, 5'-OH), 5.19 (1H, d, J 4.6, 3'-OH), 4.62 (1H, dd, J 11.1, 6.1, 2'-H), 4.15 (1H, m, 3'-H), 3.97 (1H, m, 4'-H), 3.69 (1H, m, 5'-HH), 3.55 (1H, m, $\left.5^{\prime} H \mathrm{H}\right), 2.23(6 \mathrm{H}, \mathrm{m}, 6 \mathrm{x}$ adamantyl $\mathrm{H}), 2.10(3 \mathrm{H}, \mathrm{m}, 3 \mathrm{x}$ adamantyl $\mathrm{H}), 1.69(6 \mathrm{H}, \mathrm{m}, 6 \mathrm{x}$ adamantyl $\mathrm{H}) ;{ }^{13} \mathrm{C}$ NMR (100 MHz, DMSO-d $d_{6} \delta 154.5,151.6,148.2,139.6,120.1,88.0,85.8,73.4,70.6,61.6,52.2,41.0$, 36.0, 29.0; HRMS $\left(\mathrm{ESI}^{+}\right) \mathrm{m} / \mathrm{z}$ calcd for $\mathrm{C}_{20} \mathrm{H}_{28} \mathrm{~N}_{5} \mathrm{O}_{4}[\mathrm{MH}]^{+}$402.2136, found 402.2137; purity UPLC 99\%, retention time $=2.66 \mathrm{~min}$.

6- $N$-((1R,2R)-2-(Benzyloxy)cyclopentyl)adenosine $(6){ }^{49} 6$ was synthesised according to the general procedure D, using $4(0.01 \mathrm{~g}, 0.02 \mathrm{mmol})$ and potassium carbonate $(0.01 \mathrm{~g}, 0.07 \mathrm{mmol})$. After purification with column chromatography (methanol/DCM, 2-3\%) product 6 was obtained as a white solid (0.01 g, 99\% yield). ${ }^{1} \mathrm{H}$ NMR (300 MHz, DMSO- $\left.d_{6}\right) \delta 8.37(1 \mathrm{H}, \mathrm{s}$, adenine $\mathrm{H}), 8.24(1 \mathrm{H}$, br s, adenine $\mathrm{H})$, $7.94(1 \mathrm{H}, \mathrm{m}, \mathrm{NH}), 7.33-7.19(5 \mathrm{H}, \mathrm{m}, 5 \mathrm{x}$ phenyl H), 5.89 (1H, d, J 6.1, 1'-H), 5.46-5.37 (2H, m, 2'-OH and 
5'-OH), 5.19 (1H, d, J 4.6, 3'-OH), 4.68-4.50 (4H, m, 1-H, 2'-H and $\left.\mathrm{CH}_{2} \mathrm{Ph}\right), 4.15$ (1H, dd, J 7.8, 4.6, 3'H), 4.05-3.94 (2H, m, 2-H and 4'-H), 3.68 (1H, dt, J 12.0, 4.1, 5'-HH), 3.56 (1H, m, 5'-HH), 2.14-1.89 $\left(2 \mathrm{H}, \mathrm{m}, 2 \mathrm{x}\right.$ cyclopentyl H), 1.77-1.56 (4H, m, 4 x cyclopentyl H); ${ }^{13} \mathrm{C}$ NMR (100 MHz, DMSO-d 6 ) $\delta 154.2$, 152.2, 139.6, 138.9, 128.1, 127.3, 127.1, 87.9, 85.8, 84.1, 73.5, 70.6, 70.1, 61.6, 30.1, 21.4; HRMS (ESI) calcd for $\mathrm{C}_{22} \mathrm{H}_{28} \mathrm{O}_{5} \mathrm{~N}_{5}[\mathrm{MH}]^{+} 442.2085$, found 442.2097; purity UPLC-MS 98\%, retention time $=2.30$ min.

6-N-((1R,2R)-2-(Hydroxy)cyclopentyl)adenosine (7). ${ }^{28} 7$ was synthesised according to the general procedure $\mathrm{C}$, using $4(0.03 \mathrm{~g}, 0.06 \mathrm{mmol})$, cyclohexene $(0.25 \mathrm{~mL}, 2.43 \mathrm{mmol})$ and $\mathrm{Pd}(\mathrm{OH})_{2} / \mathrm{C}(20$ wt. $\%, 0.01 \mathrm{~g}$ ). After purification with column chromatography (methanol/DCM, 2-8\%) product 7 was obtained as a white solid (0.02 g, 95\% yield). Minor quantities of the monoacetylated product were also isolated. ${ }^{1} \mathrm{H}$ NMR $\left(300 \mathrm{MHz}, \mathrm{DMSO}-d_{6}\right) \delta 8.37(1 \mathrm{H}, \mathrm{s}$, adenine $\mathrm{H}), 8.20(1 \mathrm{H}$, br s, adenine $\mathrm{H}), 7.74(1 \mathrm{H}$, d, $J$ 6.8, NH), 5.89 (1H, d, J 6.1, 1'-H), 5.48-5.36 (2H, m, 2'-OH and 5'-OH), 5.19 (1H, d, $J$ 4.6, 3'-OH), 4.87 (1H, m, 2-OH), 4.62 (1H, app. dd, J 11.3, 6.1, 2'-H), 4.29 (1H, br s, 1-H), 4.15 (1H, m, 3'-H), 4.06 (1H, m, 2-H), 3.97 (1H, m, 4'-H), 3.68 (1H, dt, J 11.9, 3.9, 5'-HH), 3.55 (1H, m, 5'-HH), 2.07 (1H, m, 1 x cyclopentyl H), 1.88 (1H, m, 1 x cyclopentyl H), 1.74-1.59 (2H, m, 2 x cyclopentyl H), 1.59-1.45 (2H, m, 2 x cyclopentyl H); ${ }^{13} \mathrm{C}$ NMR (100 MHz, DMSO- $\left.d_{6}\right) \delta 154.7,152.2,139.6,87.9,85.9,76.0,73.5,70.6$, 61.6, 58.8, 32.3; HRMS (ESI) calcd for $\mathrm{C}_{15} \mathrm{H}_{22} \mathrm{O}_{5} \mathrm{~N}_{5}[\mathrm{MH}]^{+}$352.1615, found 352.1616; purity UPLC-MS $99 \%$, retention time $=1.46 \mathrm{~min}$.

Tri- $O$-acetyl-6- $N$-[(3-endo)-9-methyl-9-azabicyclo[3.3.1]non-3-yl]adenosine $\quad(8) . \quad 8 \quad$ was synthesised according to the general procedure A, using chloride 2 ( $0.3 \mathrm{~g}, 0.73 \mathrm{mmol})$, (3-endo)-9-methyl9-azabicyclo[3.3.1]nonan-3-amine $(0.45 \mathrm{~g}, 2.91 \mathrm{mmol})$ and DIPEA (0.15 mL, $0.88 \mathrm{mmol})$. After purification with column chromatography (methanol/DCM, 5-10\%) product $\mathbf{8}$ was obtained as a white solid (0.21 g, 54\% yield). ${ }^{1} \mathrm{H}$ NMR (400 MHz, MeOD- $\left.d_{4}\right) \delta 8.30(1 \mathrm{H}, \mathrm{br} \mathrm{s}$, adenine $\mathrm{H}), 8.25(1 \mathrm{H}, \mathrm{s}$, adenine $\mathrm{H})$, 6.24 (1H, d, J 5.3, 1'-H), 6.03 (1H, t, J 5.3, 2'-H), 5.73 (1H, dd, J 5.3, 4.8, 3'-H), 4.83 (1H, br s, 3-H), 4.49$4.37\left(3 \mathrm{H}, \mathrm{m}, 4^{\prime}-\mathrm{H}\right.$ and 5' $\left.-\mathrm{H}_{2}\right), 3.44-3.42\left(2 \mathrm{H}, \mathrm{m}, 1-\right.$ and 5-H), $2.77\left(3 \mathrm{H}, \mathrm{s}, \mathrm{NCH}_{3}\right), 2.70-2.61(2 \mathrm{H}, \mathrm{m}, 2 \mathrm{x}$ granatyl $\mathrm{H}), 2.20-2.03\left(12 \mathrm{H}, \mathrm{m}, 3 \times \mathrm{CH}_{3}\right.$ and $3 \mathrm{x}$ granatyl $\left.\mathrm{H}\right), 1.77-1.61(3 \mathrm{H}, \mathrm{m}, 3 \mathrm{x}$ granatyl $\mathrm{H}), 1.43-1.40$ 
$\left(2 \mathrm{H}, \mathrm{m}, 2 \mathrm{x}\right.$ granatyl H); ${ }^{13} \mathrm{C} \mathrm{NMR}\left(100 \mathrm{MHz}, \mathrm{MeOD}-d_{4}\right) \delta 172.2,171.4,171.2,155.6,154.3,140.9,87.9$, 81.6, 74.3, 72.0, 64.2, 54.0, 41.7, 40.0, 32.6, 25.7, 20.6, 20.4, 20.2, 14.0; HRMS $\left(\mathrm{ESI}^{+}\right) \mathrm{m} / \mathrm{z}$ calcd for $\mathrm{C}_{25} \mathrm{H}_{35} \mathrm{~N}_{6} \mathrm{O}_{7} 531.2562[\mathrm{MH}]^{+}$, found 531.2553; purity UPLC-MS 96\%, retention time $=2.14$ min.

6- $N$-[(3-endo)-9-Methyl-9-azabicyclo[3.3.1]non-3-yl]adenosine (9). 9 was synthesised according to the general procedure $\mathrm{D}$, using $8(0.05 \mathrm{~g}, 0.10 \mathrm{mmol})$ and potassium carbonate $(0.005 \mathrm{~g}, 0.03 \mathrm{mmol})$. The crude product was dissolved in acetone and passed through filtered paper to give $\mathbf{9}$ as a white solid (0.04 g, 99\% yield). ${ }^{1} \mathrm{H}$ NMR (300 MHz, MeOH- $\left.d_{4}\right) \delta 8.24(1 \mathrm{H}, \mathrm{s}$, adenine $\mathrm{H}), 8.21(1 \mathrm{H}$, br s, adenine $\mathrm{H})$, $5.95\left(1 \mathrm{H}, \mathrm{d}, J 6.5,1^{\prime}-\mathrm{H}\right), 4.77$ (1H, br s overlapping, 3-H), 4.74 (1H, dd, J 6.4, 5.2, 2'-H), 4.32 (1H, dd, $J$ 5.1, 2.5, 3'-H), 4.17 (1H, app q, J 2.4, 4'-H), 3.89 (1H, dd, $J$ 12.6, 2.4, 5'-HH), 3.74 (1H, dd, J 12.6, 2.6, 5'-HH), 3.13-3.10 (2H, m, 1- and 5-H), 2.60-2.50 (5H, m, $\mathrm{NCH}_{3}$ and 2 x granatyl $\left.\mathrm{H}\right), 2.16-1.98$ (3H, m, 3 x granatyl H), 1.58-1.45 (3H, m, 3 x granatyl H), 1.16-1.12 (2H, m, 2 x granatyl $\mathrm{H}) ;{ }^{13} \mathrm{C} \mathrm{NMR}(100 \mathrm{MHz}$, $\left.\mathrm{MeOH}-d_{4}\right) \delta 153.7,141.4,128.5,91.4,88.3,75.5,72.7,63.6,52.7,42.7,40.8,33.4,25.8,15.0 ;$ HRMS (ESI) calcd for $\mathrm{C}_{19} \mathrm{H}_{29} \mathrm{O}_{4} \mathrm{~N}_{6}[\mathrm{MH}]^{+} 405.2245$, found 405.2243; purity UPLC-MS 99\%, retention time $=1.41$ $\min$.

\section{6- $N$-(1-Adamantyl)-5' -ethylamino-2',3'-O-isopropylidene-5' -oxo-5' -deoxyadenosine (11). 11}

was synthesised according to the general procedure A, using chloride $\mathbf{1 0}(0.3 \mathrm{~g}, 0.82 \mathrm{mmol})$, amantadine hydrochloride $(0.46 \mathrm{~g}, 2.45 \mathrm{mmol})$ and DIPEA $(2.61 \mathrm{~mL}, 15.01 \mathrm{mmol})$. After purification with column chromatography (methanol/DCM, 2\%) product 11 was obtained as a white solid $\left(0.28 \mathrm{~g}, 72 \%\right.$ yield). ${ }^{1} \mathrm{H}$ NMR (300 MHz, DMSO- $\left.d_{6}\right) \delta 8.27(1 \mathrm{H}, \mathrm{s}$, adenine $\mathrm{H}), 8.17(1 \mathrm{H}, \mathrm{s}$, adenine $\mathrm{H}), 7.51(1 \mathrm{H}, \mathrm{t}, J$ 5.6, amide $\mathrm{NH}), 6.62(1 \mathrm{H}, \mathrm{s}$, amine $\mathrm{NH}), 6.34\left(1 \mathrm{H}, \mathrm{d}, J 1.5,1^{\prime}-\mathrm{H}\right), 5.41(1 \mathrm{H}, \mathrm{dd}, J$ 6.1, 1.5, 2'-H), 5.38 (1H, dd, J 6.1, 1.8, 3'-H), $4.53\left(1 \mathrm{H}, \mathrm{d}, J\right.$ 1.8, 4'-H), $2.80\left(2 \mathrm{H}, \mathrm{m}, \mathrm{CH}_{2} \mathrm{CH}_{3}\right), 2.21(6 \mathrm{H}, \mathrm{m}, 6$ x adamantyl H), 2.09 (3H, m, 3 x adamantyl H), $1.68(6 \mathrm{H}, \mathrm{m}, 6 \mathrm{x}$ adamantyl $\mathrm{H}), 1.54\left(3 \mathrm{H}, \mathrm{s}, \mathrm{CH}_{3}\right), 1.35\left(3 \mathrm{H}, \mathrm{s}, \mathrm{CH}_{3}\right), 0.62(3 \mathrm{H}, \mathrm{t}, J$ 7.2, $\left.\mathrm{CH}_{2} \mathrm{CH}_{3}\right) ;{ }^{13} \mathrm{C}$ NMR $\left(100 \mathrm{MHz}, \mathrm{DMSO}-d_{6}\right) \delta 168.1,154.4,151.8,148.0,139.9,119.6,112.9,89.5,85.8$, 83.2, 83.0, 52.1, 41.0, 36.0, 33.0, 29.0, 26.7, 25.0, 13.8; HRMS $\left(\mathrm{ESI}^{+}\right) \mathrm{m} / z$ calcd for $\mathrm{C}_{25} \mathrm{H}_{35} \mathrm{~N}_{6} \mathrm{O}_{4}[\mathrm{MH}]^{+}$ 483.2714, found 483.2718 . 


\section{6- $N$-(3-Hydroxy-1-adamantyl)-5'-ethylamino-2',3'-O-isopropylidene-5' -oxo-5'-}

deoxyadenosine (12). 12 was synthesised according to the general procedure A, using chloride $10(0.07 \mathrm{~g}$, $0.19 \mathrm{mmol}), 3$-amino-1-adamantanol $(0.05 \mathrm{~g}, 0.29 \mathrm{mmol})$ and triethylamine $(0.5 \mathrm{~mL}, 3.6 \mathrm{mmol})$. After purification with column chromatography (methanol/DCM, 2-5\%) product 12 was obtained as a white solid (0.07 g, 78\% yield). ${ }^{1} \mathrm{H}$ NMR (300 MHz, DMSO- $\left.d_{6}\right) \delta 8.26(1 \mathrm{H}, \mathrm{s}$, adenine $\mathrm{H}), 8.16(1 \mathrm{H}, \mathrm{s}$, adenine $\mathrm{H})$, 7.49 (1H, t, J 5.6, amide NH), $6.74(1 \mathrm{H}, \mathrm{s}$, amine NH), 6.33 (1H, d, $J$ 1.1, 1'-H), 5.43-5.35 (2H, m, 2'-H and 3'- $\mathrm{H}), 4.53$ (2H, s, 4'- $\mathrm{H}$ and $\mathrm{OH}), 2.81\left(2 \mathrm{H}, \mathrm{m}, \mathrm{CH}_{2} \mathrm{CH}_{3}\right), 2.18-2.01$ (8H, m, 8 x adamantyl H), 1.65$1.43\left(9 \mathrm{H}, \mathrm{m}, 6 \mathrm{x}\right.$ adamantyl $\mathrm{H}$ and $\left.\mathrm{CH}_{3}\right), 1.34\left(3 \mathrm{H}, \mathrm{s}, \mathrm{CH}_{3}\right), 0.62\left(3 \mathrm{H}, \mathrm{t}, J\right.$ 7.2, $\left.\mathrm{CH}_{2} \mathrm{CH}_{3}\right) ;{ }^{13} \mathrm{C} \mathrm{NMR}(100$ MHz, DMSO- $\left.d_{6}\right) \delta 168.1,154.3,151.7,148.1,140.0,119.6,112.9,89.5,85.6,83.2,83.0,67.5,54.6,48.9$, 44.2, 34.9, 33.0, 30.1, 26.7, 25.0, 13.8; HRMS $\left(\mathrm{ESI}^{+}\right) \mathrm{m} / z$ calcd for $\mathrm{C}_{25} \mathrm{H}_{35} \mathrm{~N}_{6} \mathrm{O}_{5} 499.2663[\mathrm{MH}]^{+}$, found 499.2650; purity UPLC-MS 99\%, retention time $=2.62 \mathrm{~min}$.

6- $N$-(2-Adamantyl)-5' 'ethylamino-2',3'-O-isopropylidene-5'-oxo-5' -deoxyadenosine (13). 13 was synthesised according to the general procedure A, using chloride $10(0.02 \mathrm{~g}, 0.06 \mathrm{mmol})$, 2adamantylamine hydrochloride $(0.03 \mathrm{~g}, 0.18 \mathrm{mmol})$ and DIPEA $(0.05 \mathrm{~mL}, 0.27 \mathrm{mmol})$. After purification with column chromatography (methanol/DCM, 2\%) product 13 was obtained as a white solid (0.02 g, 69\% yield). ${ }^{1} \mathrm{H}$ NMR (300 MHz, DMSO- $\left.d_{6}\right) \delta 8.29(1 \mathrm{H}, \mathrm{s}$, adenine $\mathrm{H}), 8.17(1 \mathrm{H}$, br s, adenine H), 7.48 (1H, t, $J$ 5.7, amide $\mathrm{NH}), 7.05$ (1H, br s, NH), 6.34 (1H, s, 1'-H), 5.45-5.36 (2H, m, 2'- and 3'-H), 4.53 (1H, s, 4'$\mathrm{H}), 4.36\left(1 \mathrm{H}\right.$, br s, adamantyl H), $2.80\left(2 \mathrm{H}, \mathrm{m}, \mathrm{CH}_{2} \mathrm{CH}_{3}\right), 2.11-2.05(4 \mathrm{H}, \mathrm{m}, 4 \mathrm{x}$ adamantyl $\mathrm{H}), 1.84(6 \mathrm{H}$, m, 6 x adamantyl $\mathrm{H}), 1.72(2 \mathrm{H}, \mathrm{m}, 2 \mathrm{x}$ adamantyl $\mathrm{H}), 1.53-1.50\left(5 \mathrm{H}, \mathrm{m}, 2 \mathrm{x}\right.$ adamantyl $\mathrm{H}$ and $\left.\mathrm{CH}_{3}\right), 1.34$ $\left(3 \mathrm{H}, \mathrm{s}, \mathrm{CH}_{3}\right), 0.59\left(3 \mathrm{H}, \mathrm{t}, J 7.2, \mathrm{CH}_{2} \mathrm{CH}_{3}\right) ;{ }^{13} \mathrm{C}$ NMR (100 MHz, DMSO- $\left.d_{6}\right) \delta 168.1,154.1,152.3,140.3$, 112.9, 89.5, 85.9, 83.2, 83.1, 37.1, 36.9, 36.8, 33.0, 30.9, 26.7, 26.6, 25.0, 13.8; HRMS (ESI) calculated for $\mathrm{C}_{25} \mathrm{H}_{35} \mathrm{~N}_{6} \mathrm{O}_{4}[\mathrm{MH}]^{+}$483.2714, found 483.2707; purity UPLC-MS 94\%, retention time $=3.12$ min.

\section{6- $N$-[(3-endo)-9-Methyl-9-azabicyclo[3.3.1]non-3-yl]-5' -ethylamino-2',3'-O-isopropylidene-}

5'-oxo-5'-deoxyadenosine (14). 14 was synthesised according to the general procedure A, using chloride 10 (0.1 g, $0.27 \mathrm{mmol})$, (3-endo)-9-methyl-9-azabicyclo[3.3.1]nonan-3-amine (0.17 g, $1.09 \mathrm{mmol})$ and 
DIPEA (0.06 mL, $0.33 \mathrm{mmol})$. After purification with column chromatography (methanol/DCM, 5-10\%) product 14 was obtained as a white solid $(0.11 \mathrm{~g}, 85 \%$ yield $) .{ }^{1} \mathrm{H}$ NMR $\left(300 \mathrm{MHz}, \mathrm{MeOD}-d_{4}\right) \delta 8.21(2 \mathrm{H}$, m, 2 x adenine H), 6.35 (1H, d, $J$ 1.0, ' '-H), $5.63\left(1 \mathrm{H}, \mathrm{dd}, J 6.1,1.8,3^{\prime}-\mathrm{H}\right), 5.51$ (1H, m, 2'-H), 4.77 (1H, br s, 3-H), $4.64\left(1 \mathrm{H}, \mathrm{d}, J\right.$ 1.7, 4'-H), 3.27-3.23 (1H, m, 1- and 5-H), $2.85\left(2 \mathrm{H}, \mathrm{m}, \mathrm{CH}_{2} \mathrm{CH}_{3}\right), 2.67-2.50(5 \mathrm{H}$, m, $\mathrm{NCH}_{3}$ and $2 \mathrm{x}$ granatyl $\left.\mathrm{H}\right), 2.20-2.00(3 \mathrm{H}, \mathrm{m}, 3 \mathrm{x}$ granatyl $\mathrm{H}), 1.65-1.51\left(6 \mathrm{H}, \mathrm{m}, \mathrm{CH}_{3}\right.$ and $3 \mathrm{x}$ granatyl $\mathrm{H}), 1.42\left(3 \mathrm{H}, \mathrm{s}, \mathrm{CH}_{3}\right)$ 1.34-1.19 (2H, m, 2 x granatyl H), $0.63\left(3 \mathrm{H}, \mathrm{t}, J 7.3, \mathrm{CH}_{2} \mathrm{CH}_{3}\right) ;{ }^{13} \mathrm{C} \mathrm{NMR}(75 \mathrm{MHz}$, $\left.\mathrm{CDCl}_{3}\right)$ 171.6, 155.6, 154.1, 142.0, 114.9, 92.4, 88.7, 85.3, 85.2, 53.3, 42.2, 40.4, 34.7, 33.1, 27.1, 25.8, 25.3, 14.6, 14.0; HRMS calculated for $\mathrm{C}_{24} \mathrm{H}_{36} \mathrm{O}_{4} \mathrm{~N}_{7}[\mathrm{MH}]^{+}$486.2823, found 486.2810; purity UPLC-MS $99 \%$, retention time $=1.97 \mathrm{~min}$.

\section{6- $N-((1 R, 2 R)-2-(B e n z y l o x y) c y c l o p e n t y l)-5 '-e t h y l a m i n o-2 ', 3 '-O$-isopropylidene-5' -oxo-5'-}

deoxyadenosine (15). 15 was synthesised according to the general procedure A, using chloride $10(0.2 \mathrm{~g}$, $0.54 \mathrm{mmol}),(1 R, 2 R)$-1-amino-2-benzyloxycyclopentane $(0.15 \mathrm{~mL}, 0.82 \mathrm{mmol})$ and triethylamine $(0.21$ $\mathrm{mL}, 1.51 \mathrm{mmol}$ ). Following removal of the solvent from the reaction mixture, the residue was dissolved in ethyl acetate $(100 \mathrm{~mL})$ and washed with water $(2 \times 50 \mathrm{~mL})$. The organic phase was then dried over anhydrous $\mathrm{Na}_{2} \mathrm{SO}_{4}$ and the solvent was removed in vacuo. After purification with column chromatography (methanol/DCM, 1-3\%) product 15 was obtained as a pale yellow solid (0.22 g, 79\% yield). ${ }^{1} \mathrm{H}$ NMR (300 MHz, DMSO- $\left.d_{6}\right) \delta 8.27(1 \mathrm{H}, \mathrm{s}$, adenine H), $8.20(1 \mathrm{H}$, br s, adenine $\mathrm{H}), 7.91(1 \mathrm{H}, \mathrm{m}$, amine $\mathrm{NH}), 7.51(1 \mathrm{H}$, t, J 5.7, amide $\mathrm{NH}), 7.33-7.20(5 \mathrm{H}, \mathrm{m}, 5 \mathrm{x}$ phenyl H), $6.34(1 \mathrm{H}, \mathrm{s}, 1$ '-H), 5.43-5.36 (2H, m, 2'- and 3'-H), 4.66-4.49 (4H, m, 4'- $\mathrm{H}, \mathrm{CH}_{2} \mathrm{Ph}$ and 1-H), $4.01(1 \mathrm{H}, \mathrm{m}, 2-\mathrm{H}), 2.81\left(2 \mathrm{H}, \mathrm{m}, \mathrm{CH}_{2} \mathrm{CH}_{3}\right), 2.12-1.89$ (2H, m, 2 x cyclopentyl H), 1.80-1.56 $(4 \mathrm{H}, \mathrm{m}, 4 \mathrm{x}$ cyclopentyl $\mathrm{H}), 1.54\left(3 \mathrm{H}, \mathrm{s}, \mathrm{CH}_{3}\right), 1.34\left(3 \mathrm{H}, \mathrm{s}, \mathrm{CH}_{3}\right), 0.61(3 \mathrm{H}, \mathrm{t}$, $J$ 7.2, $\left.\mathrm{CH}_{2} \mathrm{CH}_{3}\right) ;{ }^{13} \mathrm{C}$ NMR (100 MHz, DMSO- $\left.d_{6}\right) \delta 168.1,154.1,152.4,148.2,139.9,138.9,128.1,127.3$, $127.1,112.9,89.5,85.8,84.0,83.2,83.1,70.1,56.4,33.0,30.2,26.7,25.0,21.3,13.8 ;$ HRMS (ESI) calculated for $\mathrm{C}_{27} \mathrm{H}_{35} \mathrm{O}_{5} \mathrm{~N}_{6}[\mathrm{MH}]^{+}$523.2663, found 523.2649; purity UPLC-MS 99\%, retention time = 3.08 $\min$. 
6- $N$-(1-Adamantyl)-5'-ethylamino-5'-oxo-5'-deoxyadenosine $\quad$ (16). 16 was synthesised according to the general procedure $\mathrm{B}$, using $11(0.10 \mathrm{~g}, 0.21 \mathrm{mmol})$, acetic acid $(10 \mathrm{~mL})$ and water $(3 \mathrm{~mL})$. After purification with column chromatography (methanol/DCM, 2-6\%) product 16 was obtained as a white solid (0.09 g, $96 \%$ yield). ${ }^{1} \mathrm{H}$ NMR $\left(300 \mathrm{MHz}, \mathrm{DMSO}-d_{6}\right) \delta 8.89(1 \mathrm{H}, \mathrm{t}, J 5.5$, amide $\mathrm{NH}), 8.39(1 \mathrm{H}$, s, adenine H), $8.27(1 \mathrm{H}, \mathrm{s}$, adenine $\mathrm{H}), 6.77(1 \mathrm{H}, \mathrm{s}$, amine $\mathrm{NH}), 5.95(1 \mathrm{H}, \mathrm{d}, J 7.7,1$ '- $\mathrm{H}), 5.75(1 \mathrm{H}, \mathrm{d}, J 3.8$, 3'-OH), 5.56 (1H, d, J 6.2, 2'-OH), 4.61 (1H, m, 2'-H), 4.30 (1H, d, J 1.2, 4'-H), 4.14 (1H, m, 3'-H), 3.22 $\left(2 \mathrm{H}, \mathrm{m}, \mathrm{CH}_{2} \mathrm{CH}_{3}\right), 2.23(6 \mathrm{H}, \mathrm{m}, 6 \mathrm{x}$ adamantyl H), $2.09(3 \mathrm{H}, \mathrm{m}, 3 \mathrm{x}$ adamantyl $\mathrm{H}), 1.68(6 \mathrm{H}, \mathrm{m}, 6 \mathrm{x}$ adamantyl H), $1.08\left(3 \mathrm{H}, \mathrm{t}, J\right.$ 7.2, $\left.\mathrm{CH}_{2} \mathrm{CH}_{3}\right) ;{ }^{13} \mathrm{C}$ NMR (100 MHz, DMSO-d $) \delta$ 169.1, 154.6, 151.6, 148.0, $140.4,120.4,87.9,84.7,73.1,71.9,52.2,41.0,36.0,33.2,29.0,14.7 ;$ IR $\left[\mathrm{cm}^{-1}\right] 3218,2905,2847,1644$; HRMS $\left(\mathrm{ESI}^{+}\right) \mathrm{m} / z$ calcd for $\mathrm{C}_{22} \mathrm{H}_{31} \mathrm{~N}_{6} \mathrm{O}_{4}[\mathrm{MH}]^{+}$443.2401, found 443.2393; purity UPLC 99\%, retention time $=3.06 \mathrm{~min}$.

6- $N$-(3-Hydroxy-1-adamantyl)-5'-ethylamino-5' '-oxo-5' -deoxyadenosine $\quad(17) . \quad 17$ was synthesised according to the general procedure B, using $12(0.01 \mathrm{~g}, 0.02 \mathrm{mmol})$, acetic acid (3.6 $\mathrm{mL})$ and water $(1.2 \mathrm{~mL})$. After purification with column chromatography (methanol/DCM, 1-5\%) product 17 was obtained as a white solid (0.007 g, 78\% yield). ${ }^{1} \mathrm{H}$ NMR (300 MHz, DMSO- $\left.d_{6}\right) \delta 8.88(1 \mathrm{H}, \mathrm{t}, J 5.5$, amide NH), $8.40(1 \mathrm{H}, \mathrm{s}$, adenine H), 8.27 (1H, s, adenine H), 6.89 (1H, s, amine NH), $5.95(1 \mathrm{H}, \mathrm{d}, J$ 7.6, 1'-H), $5.74(1 \mathrm{H}, \mathrm{d}, J$ 4.2, 3'-OH), 5.57 (1H, d, J 6.4, 2'-OH), 4.61 (1H, m, 2'-H), 4.55 (1H, s, adamantyl $\mathrm{OH})$, $4.30\left(1 \mathrm{H}, \mathrm{d}, J\right.$ 1.2, 4'-H), $4.14\left(1 \mathrm{H}, \mathrm{m}, 3^{\prime}-\mathrm{H}\right), 3.21\left(2 \mathrm{H}, \mathrm{m}, \mathrm{CH}_{2} \mathrm{CH}_{3}\right), 2.20-2.05(8 \mathrm{H}, \mathrm{m}, 8$ x adamantyl H), 1.66-1.43 (6H, m, 6 x adamantyl H), $1.08\left(3 \mathrm{H}, \mathrm{t}, J 7.2, \mathrm{CH}_{2} \mathrm{CH}_{3}\right) ;{ }^{13} \mathrm{C}$ NMR (100 MHz, DMSO-d 6 ) $\delta 169.1$, $154.5,151.6,148.0,140.4,120.3,87.8,84.7,73.1,72.0,67.5,54.7,48.8,44.2,34.9,33.3,30.1,14.7$; HRMS $\left(\mathrm{ESI}^{+}\right) \mathrm{m} / \mathrm{z}$ calcd for $\mathrm{C}_{22} \mathrm{H}_{31} \mathrm{~N}_{6} \mathrm{O}_{5}[\mathrm{MH}]^{+}$459.2350, found 459.2346; purity UPLC 94\%, retention time $=2.18 \mathrm{~min}$.

6- $N$-(2-Adamantyl)-5' 'ethylamino-5' -oxo-5'-deoxyadenosine $\quad(18) . \quad 18$ was synthesised according to the general procedure B, using $13(0.02 \mathrm{~g}, 0.04 \mathrm{mmol})$, acetic acid $(1.6 \mathrm{~mL})$ and water $(0.4$ $\mathrm{mL}$ ). After purification with column chromatography (methanol/DCM, 3-10\%) product 18 was obtained 
as a white solid (0.02 g, 99\% yield). ${ }^{1} \mathrm{H}$ NMR $\left(300 \mathrm{MHz}, \mathrm{DMSO}-d_{6}\right) \delta 8.86(1 \mathrm{H}, \mathrm{m}$, amide $\mathrm{NH}), 8.43(1 \mathrm{H}$, s, adenine $\mathrm{H}), 8.27(1 \mathrm{H}, \mathrm{s}$, adenine $\mathrm{H}), 7.15(1 \mathrm{H}$, br s, amine $\mathrm{NH}), 5.97\left(1 \mathrm{H}, \mathrm{d}, J 7.5,1^{\prime}-\mathrm{H}\right), 5.74(1 \mathrm{H}, \mathrm{d}, J$ 4.3, 3'-OH), $5.54\left(1 \mathrm{H}, \mathrm{d}, J\right.$ 6.4, 2'-OH), $4.62\left(1 \mathrm{H}, \mathrm{m}, 2^{\prime}-\mathrm{H}\right), 4.37$ (1H, br s, adamantyl H), 4.30 (1H, d, $J$ 1.4, 4'-H), $4.14\left(1 \mathrm{H}, \mathrm{m}, 3^{\prime}-\mathrm{H}\right), 3.21\left(2 \mathrm{H}, \mathrm{m}, \mathrm{CH}_{2} \mathrm{CH}_{3}\right), 2.13-2.08(4 \mathrm{H}, \mathrm{m}, 4 \mathrm{x}$ adamantyl $\mathrm{H}), 1.85(6 \mathrm{H}, \mathrm{m}$, 6 x adamantyl H), $1.73(2 \mathrm{H}, \mathrm{m}, 2 \mathrm{x}$ adamantyl $\mathrm{H}), 1.56-1.52(2 \mathrm{H}, \mathrm{m}, 2 \mathrm{x}$ adamantyl $\mathrm{H}), 1.08$ (3H, t, J 7.2, $\left.\mathrm{CH}_{2} \mathrm{CH}_{3}\right) ;{ }^{13} \mathrm{C}$ NMR $\left(100 \mathrm{MHz}, \mathrm{DMSO}-d_{6}\right) \delta 169.1,154.3,152.3,140.6,114.5,87.8,84.6,73.1,71.9,37.2$, 36.9, 33.3, 30.9, 26.8, 14.7; HRMS (ESI) calcd for $\mathrm{C}_{22} \mathrm{H}_{31} \mathrm{~N}_{6} \mathrm{O}_{4}[\mathrm{MH}]^{+}$443.2401, found 443.2392; purity UPLC-MS 99\%, retention time $=2.69 \mathrm{~min}$.

\section{6-N-[(3-endo)-9-Methyl-9-azabicyclo[3.3.1] non-3-yl]-5'-ethylamino-5'-0xo-5'-}

deoxyadenosine (19). 19 was synthesised according to the general procedure B, using 14 (0.03 g, 0.06 $\mathrm{mmol})$, acetic acid $(4.8 \mathrm{~mL})$ and water $(1.2 \mathrm{~mL})$. After purification with column chromatography (methanol/DCM, 5-10\%, with an additional 1\% aqueous ammonia) product 19 was obtained as a white solid (0.03 g, 99\% yield). ${ }^{1} \mathrm{H}$ NMR (300 MHz, MeOD- $\left.d_{4}\right) \delta 8.30(1 \mathrm{H}$, br s, adenine $\mathrm{H}), 8.27(1 \mathrm{H}$, s, adenine H), 6.01 (1H, d, J 7.7, 1'-H), 4.81 (1H partially behind solvent signal, m, 3-H), 4.75 (1H, dd, J 7.6, 4.8, 2'H), $4.47\left(1 \mathrm{H}, \mathrm{d}, J 1.5,4^{\prime}-\mathrm{H}\right), 4.31\left(1 \mathrm{H}, \mathrm{dd}, J 4.8,1.4,3^{\prime}-\mathrm{H}\right), 3.37\left(2 \mathrm{H}, \mathrm{m}, \mathrm{CH}_{2} \mathrm{CH}_{3}\right), 3.28$ (2H partially behind solvent signal, $\mathrm{m}, 1-$ and 5-H), 2.69-2.56 (5H, m, $\mathrm{NCH}_{3}$ and $2 \mathrm{x}$ granatyl $\left.\mathrm{H}\right), 2.21-2.04(3 \mathrm{H}, \mathrm{m}, 3 \mathrm{x}$ granatyl H), 1.68-1.56 $(3 \mathrm{H}, \mathrm{m}, 3$ x granatyl $\mathrm{H}), 1.30(2 \mathrm{H}, \mathrm{m}, 2 \mathrm{x}$ granatyl $\mathrm{H}), 1.21\left(3 \mathrm{H}, \mathrm{t}, J\right.$ 7.3, $\left.\mathrm{CH}_{2} \mathrm{CH}_{3}\right)$; ${ }^{13} \mathrm{C}$ NMR (100 MHz, MeOD- $\left.d_{4}\right) \delta 172.1,155.8,153.9,142.1,90.5,86.5,75.0,73.4,53.5,42.1,40.2,35.1$, 33.0, 25.7, 15.0, 14.4; HRMS (ESI) calcd for $\mathrm{C}_{21} \mathrm{H}_{32} \mathrm{~N}_{7} \mathrm{O}_{4}[\mathrm{MH}]^{+} 446.2510$, found 446.2523; purity UPLCMS 99\%, retention time $=1.62 \mathrm{~min}$.

6- $N$-((1R,2R)-2-(Benzyloxy)cyclopentyl)-5' -ethylamino-5' -oxo-5'-deoxyadenosine $\quad(20) . \quad 20$ was synthesised according to the general procedure B, using $15(0.01 \mathrm{~g}, 0.02 \mathrm{mmol})$, acetic acid (1.6 $\mathrm{mL})$ and water $(0.4 \mathrm{~mL})$. After purification with column chromatography (methanol/DCM, 2-4\%) product 20 was obtained as a white solid (0.01 g, 99\% yield). ${ }^{1} \mathrm{H}$ NMR (400 MHz, DMSO- $\left.d_{6}\right) \delta 8.90(1 \mathrm{H}, \mathrm{t}, J$ 5.6, amide $\mathrm{NH}), 8.41(1 \mathrm{H}, \mathrm{s}$, adenine $\mathrm{H}), 8.30(1 \mathrm{H}, \mathrm{br} \mathrm{s}$, adenine $\mathrm{H}), 8.03(1 \mathrm{H}, \mathrm{m}$, amine $\mathrm{NH}), 7.33-7.20(5 \mathrm{H}$, 
m, 5 x phenyl H), $5.98(1 \mathrm{H}, \mathrm{d}, J$ 7.6, 1'-H), $5.73(1 \mathrm{H}, \mathrm{d}, J$ 4.3, 3'-OH), 5.53 (1H, d, J 6.5, 2'-OH), 4.674.53 (4H, m, 2'-H, $\mathrm{CH}_{2} \mathrm{Ph}$ and 1-H), 4.32 (1H, d, J 1.5, 4'-H), 4.15 (1H, m, 3'-H), 4.03 (1H, m, 2-H), 3.23 $\left(2 \mathrm{H}, \mathrm{m}, \mathrm{CH}_{2} \mathrm{CH}_{3}\right), 2.08(1 \mathrm{H}, \mathrm{m}, 1$ x cyclopentyl H), $1.96(1 \mathrm{H}, \mathrm{m}, 1 \mathrm{x}$ cyclopentyl H), 1.79-1.60 (4H, m, 4 x cyclopentyl H), $1.09\left(3 \mathrm{H}, \mathrm{t}, J\right.$ 7.2, $\left.\mathrm{CH}_{2} \mathrm{CH}_{3}\right) ;{ }^{13} \mathrm{C}$ NMR (100 MHz, DMSO-d $\left.d_{6}\right) \delta 169.1,154.3,152.3$, $140.4,138.9,128.1,127.3,127.1,120.1,87.8,84.7,84.1,73.1,72.0,70.1,56.4,33.2,30.2,21.4,14.7$; HRMS (ESI) calcd for $\mathrm{C}_{24} \mathrm{H}_{31} \mathrm{O}_{5} \mathrm{~N}_{6}[\mathrm{MH}]^{+}$483.2350, found 483.2339; purity UPLC-MS 98\%, retention time $=2.59 \mathrm{~min}$.

6- $N$-((1R,2R)-2-(Hydroxy)cyclopentyl)-5'-ethylamino-5' -oxo-5'-deoxyadenosine (21). 21 was synthesised according to the general procedure C, using $\mathbf{2 0}(0.08 \mathrm{~g}, 0.17 \mathrm{mmol})$, cyclohexene $(0.66 \mathrm{~mL}$, $6.55 \mathrm{mmol})$ and $\mathrm{Pd}(\mathrm{OH})_{2} / \mathrm{C}(20$ wt. \%, $0.02 \mathrm{~g})$. After purification with column chromatography (methanol/DCM, 2-8\%) product 21 was obtained as a white solid (0.07 g, 99\% yield). ${ }^{1} \mathrm{H}$ NMR (300 MHz, DMSO- $\left.d_{6}\right) \delta 8.91(1 \mathrm{H}, \mathrm{t}, J 5.4 \mathrm{~Hz}$, amide $\mathrm{NH}), 8.41(1 \mathrm{H}, \mathrm{s}$, adenine $\mathrm{H}), 8.26(1 \mathrm{H}$, br s, adenine $\mathrm{H}), 7.84$ (1H, m, amine NH), 5.97 (1H, d, J 7.6, 1'-H), 5.75 (1H, d, J 4.3, 3'-OH), 5.55 (1H, d, J 6.5, 2'-OH), 4.86 (1H, m, 2-OH), 4.62 (1H, m, 2'-H), 4.31 (2H, m, 1-H and 4'-H), $4.14(1 \mathrm{H}, \mathrm{m}, 3$ '-H), 4.06 (1H, m, 2-H), $3.23\left(2 \mathrm{H}, \mathrm{m}, \mathrm{CH}_{2} \mathrm{CH}_{3}\right), 2.10(1 \mathrm{H}, \mathrm{m}, 1 \mathrm{x}$ cyclopentyl $\mathrm{H}), 1.90(1 \mathrm{H}, \mathrm{m}, 1 \mathrm{x}$ cyclopentyl $\mathrm{H}), 1.74-1.42(4 \mathrm{H}$, m, 4 x cyclopentyl H), 1.09 (3H, t, $J$ 7.2, $\left.\mathrm{CH}_{2} \mathrm{CH}_{3}\right) ;{ }^{13} \mathrm{C}$ NMR (100 MHz, DMSO- $\left.d_{6}\right) \delta 169.1,154.8,152.2$, $140.3,87.8,84.6,76.0,73.1,72.0,58.8,33.3,32.3,20.4,14.7$; HRMS (ESI) calcd for $\mathrm{C}_{17} \mathrm{H}_{25} \mathrm{O}_{5} \mathrm{~N}_{6}[\mathrm{MH}]^{+}$ 393.1881, found 393.1873; purity UPLC-MS 99\%, retention time $=2.21 \mathrm{~min}$.

\section{6-N-[(3-endo)-3-tert-Butyloxycarbonylamino-9-azabicyclo[3.3.1]non-3-yl]-5'-ethylamino-}

2',3'-O-isopropylidene-5'-oxo-5'-deoxyadenosine (23). 23 was synthesised according to the general procedure A, using chloride 10 (0.03 g, $0.08 \mathrm{mmol})$, tert-butyl-9-azabicyclo[3.3.1]nonan-3-ylcarbamate (22) $(0.04 \mathrm{~g}, 0.16 \mathrm{mmol})$ and triethylamine $(0.41 \mathrm{~mL}, 2.94 \mathrm{mmol})$. Following removal of the solvent from the reaction mixture, the residue was dissolved in ethyl acetate $(100 \mathrm{~mL})$ and washed with water $(2 \times 50$ $\mathrm{mL}$ ). The organic phase was then dried over anhydrous $\mathrm{Na}_{2} \mathrm{SO}_{4}$ and the solvent was removed in vacuo. After purification with column chromatography (methanol/DCM, 1-2\%) product $\mathbf{2 3}$ was obtained as a pale 
yellow solid (0.03 g, 67\% yield). ${ }^{1} \mathrm{H}$ NMR (300 MHz, MeOD- $\left.d_{4}\right) \delta 8.18(1 \mathrm{H}$, s, adenine $\mathrm{H}), 8.13(1 \mathrm{H}, \mathrm{m}$, adenine $\mathrm{H}), 6.33$ (1H, s, 1'-H), 6.16 (1H, m, 1- or 5-H), 5.61 (1H, m, 2'-H), 5.49 (1H, m, 3'-H), 5.42 (1H, m, 1- or 5-H), $4.62\left(1 \mathrm{H}, \mathrm{d}, J\right.$ 1.7, 4'-H), $3.29\left(1 \mathrm{H}, \mathrm{m}\right.$, granatyl H), $2.85\left(2 \mathrm{H}, \mathrm{m}, \mathrm{CH}_{2} \mathrm{CH}_{3}\right), 2.42-2.16(3 \mathrm{H}$, m, 3 x granatyl $\mathrm{H}), 1.79-1.34\left(22 \mathrm{H}, \mathrm{m}, 2 \times \mathrm{CH}_{3},-\mathrm{C}\left(\mathrm{CH}_{3}\right)_{3}\right.$ and $7 \mathrm{x}$ granatyl $\left.\mathrm{H}\right), 0.66(3 \mathrm{H}, \mathrm{dt}, J$ 14.7, 7.2 , $\left.\mathrm{CH}_{2} \mathrm{CH}_{3}\right) ;{ }^{13} \mathrm{C}$ NMR $\left(75 \mathrm{MHz}, \mathrm{CDCl}_{3}\right)$ 171.8, 155.4, 153.7, 140.6, 117.1, 115.0, 93.0, 88.9, 85.5, 85.3, 45.1, 44.1, 35.0, 33.6, 33.2, 32.5, 31.8, 30.9, 28.9, 27.2, 25.5, 15.0, 14.3; HRMS calculated for $\mathrm{C}_{28} \mathrm{H}_{42} \mathrm{O}_{6} \mathrm{~N}_{7}[\mathrm{MH}]^{+}$ 572.3191, found 572.3187.

\section{6- $N$-[(3-endo)-3-Amino-9-azabicyclo[3.3.1] non-3-yl]-5'-ethylamino-5'-oxo-5'-}

deoxyadenosine (24). 24 was synthesised according to the general procedure B, using 23 (0.02 g, 0.03 $\mathrm{mmol})$, acetic acid $(1.5 \mathrm{~mL})$ and water $(0.5 \mathrm{~mL})$. The crude product was purified by prep-LC, with an eluent gradient of $100 \%$ A to $60 \% \mathrm{D}$ in 40 minutes. The fractions were collected and dried by lyophilization and product 24 was obtained as a white solid as the TFA salt (0.03 g, 99\% yield). ${ }^{1} \mathrm{H}$ NMR $(400 \mathrm{MHz}, \mathrm{MeOD}-$ $\left.d_{4}\right) \delta 8.34(1 \mathrm{H}, \mathrm{s}$, adenine $\mathrm{H}), 8.28(1 \mathrm{H}, \mathrm{s}$, adenine $\mathrm{H}), 6.35(1 \mathrm{H}, \mathrm{br} \mathrm{s}, 1-$ or $5-\mathrm{H}), 6.03(1 \mathrm{H}, \mathrm{d}, J$ 7.6, 1'- $\mathrm{H})$, 5.59 (1H, br s, 1- or 5-H), 4.74 (1H, dd, J 7.5, 4.8, 2'-H), 4.48 (1H, d, J 1.6, 4'-H), 4.30 (1H, dd, J 4.8, 1.5, 3'-H), 3.36 (2H, q, J 7.3, $\left.\mathrm{CH}_{2} \mathrm{CH}_{3}\right), 3.00$ (1H, ddd, $J$ 18.3, 12.2, 5.8, 3-H), 2.57 (2H, m, 2 x granatyl H), $2.18(1 \mathrm{H}, \mathrm{m}, 1 \mathrm{x}$ granatyl $\mathrm{H}), 1.87-1.64(7 \mathrm{H}, \mathrm{m}, 7 \mathrm{x}$ granatyl $\mathrm{H}), 1.20\left(3 \mathrm{H}, \mathrm{t}, J \mathrm{~J} .3, \mathrm{CH}_{2} \mathrm{CH}_{3}\right) ;{ }^{13} \mathrm{C}$ NMR $\left(100 \mathrm{MHz}, \mathrm{MeOD}-d_{4}\right) \delta 172.2,155.2,152.6,150.7,141.1,121.8,90.6,86.4,75.0,73.5,45.1,35.1,31.0$, 15.0, 14.7; ${ }^{19} \mathrm{~F}$ NMR (376 MHz, DMSO- $\left.d_{6}\right) \delta$-77.3; HRMS (ESI) calcd for $\mathrm{C}_{20} \mathrm{H}_{30} \mathrm{O}_{4} \mathrm{~N}_{7}[\mathrm{MH}]^{+} 432.2354$, found 432.2343; purity UPLC-MS 99\%, retention time $=1.80 \mathrm{~min}$.

\section{6- $N$-[(3-endo)-3-Aminodimethyl-9-azabicyclo[3.3.1]non-3-yl]-5'-ethylamino-5' -oxo-5'-}

deoxyadenosine (25). Formic acid $(0.02 \mathrm{~mL})$ and formaldehyde $(37 \%$ aq. solution, $0.04 \mathrm{~mL})$ were added to $24(0.01 \mathrm{~g}, 0.02 \mathrm{mmol})$ and stirred at $90{ }^{\circ} \mathrm{C}$ overnight. Additional formic acid $(0.02 \mathrm{~mL})$ and formaldehyde ( $37 \%$ aq. solution, $0.04 \mathrm{~mL}$ ) were added and stirred at $105{ }^{\circ} \mathrm{C}$ for $3 \mathrm{~h}$. The reaction mixture was allowed to cool to room temperature and made alkaline with $1 \mathrm{M} \mathrm{NaOH}$ solution. This was then thoroughly extracted with ethyl acetate $(3 \times 100 \mathrm{~mL})$ and the combined organic extracts were washed with 
sat. aq. $\mathrm{NaHCO}_{3}(50 \mathrm{~mL})$, water $(50 \mathrm{~mL})$ and brine $(50 \mathrm{~mL})$, dried over anhydrous $\mathrm{Na}_{2} \mathrm{SO}_{4}$ and the solvent removed in vacuo to give 25 as white solid (0.006 g, 67\% yield). ${ }^{1} \mathrm{H}$ NMR (300 MHz, MeOH- $\left.d_{4}\right) \delta 8.27$ $(1 \mathrm{H}, \mathrm{s}$, adenine $\mathrm{H}), 8.21(1 \mathrm{H}, \mathrm{s}$, adenine $\mathrm{H}), 6.26\left(1 \mathrm{H}\right.$, br s, 1 - or 5-H), $6.01\left(1 \mathrm{H}, \mathrm{d}, J 7.6,1^{\prime}-\mathrm{H}\right), 5.49(1 \mathrm{H}$, br s, 1- or 5-H), 4.78 (1H, dd, J 7.7, 4.8, 2'-H), 4.46 (1H, d, J 1.4, 4'-H), 4.30 (1H, dd, J 4.8, 1.4, 3'-H), $3.38\left(2 \mathrm{H}, \mathrm{m}, \mathrm{CH}_{2} \mathrm{CH}_{3}\right), 2.45\left(9 \mathrm{H}, \mathrm{m}, 2 \mathrm{x} \mathrm{CH}_{3}\right.$ and $3 \mathrm{x}$ granatyl $\left.\mathrm{H}\right), 2.18(1 \mathrm{H}, \mathrm{m}, 1 \mathrm{x}$ granatyl $\mathrm{H}), 1.77-1.58$ $\left(7 \mathrm{H}, \mathrm{m}, 7 \mathrm{x}\right.$ granatyl H), $1.20\left(3 \mathrm{H}, \mathrm{t}, J 7.3, \mathrm{CH}_{2} \mathrm{CH}_{3}\right) ;{ }^{13} \mathrm{C}$ NMR $\left(100 \mathrm{MHz}, \mathrm{DMSO}-d_{6}\right) \delta 172.1,155.1$, 153.3, 151.5, 140.8, 121.6, 90.4, 86.4, 75.0, 73.2, 58.6, 41.8, 35.1, 30.8, 15.1, 14.9; HRMS (ESI) calcd for $\mathrm{C}_{22} \mathrm{H}_{34} \mathrm{O}_{4} \mathrm{~N}_{7}[\mathrm{MH}]^{+} 460.2667$, found 460.2661; purity UPLC-MS 99\%, retention time $=1.87$ min.

\section{6- $N$-(1-Adamantyl)-5'-(2-fluorophenylthio)-2',3'-O-isopropylidene-5'-deoxyadenosine $\quad(30)$.}

$\mathbf{3 0}$ was synthesised according to the general procedure A, using chloride $\mathbf{2 9}(0.1 \mathrm{~g}, 0.23 \mathrm{mmol})$, amantadine hydrochloride $(0.13 \mathrm{~g}, 0.69 \mathrm{mmol})$ and DIPEA $(0.18 \mathrm{~mL}, 1.03 \mathrm{mmol})$. After purification with column chromatography (methanol/DCM, 0.5\%) product 30 was obtained as a white solid (0.09 g, 69\% yield). ${ }^{1} \mathrm{H}$ NMR (300 MHz, DMSO- $\left.d_{6}\right) \delta 8.29(1 \mathrm{H}, \mathrm{s}$, adenine H), $8.23(1 \mathrm{H}, \mathrm{s}$, adenine H), $7.38(1 \mathrm{H}, \mathrm{td}, J$ 7.8, $1.6, \mathrm{Ar}$ H), 7.31-7.07 (3H, m, 3 x Ar H), 6.67 (1H, s, amine NH), 6.17 (1H, d, J 2.2, 1'-H), 5.51 (1H, dd, J 6.2, 2.2, 2'-H), 5.05 (1H, dd, J 6.2, 2.7, 3'-H), 4.20 (1H, td, J 6.9, 2.5, 4'-H), 3.25 (2H overlapping with solvent signal, m, 5'- $\left.\mathrm{H}_{2}\right), 2.22(6 \mathrm{H}, \mathrm{m}, 6 \mathrm{x}$ adamantyl H), 2.09 (3H, m, $3 \mathrm{x}$ adamantyl $\mathrm{H}), 1.75-1.63(6 \mathrm{H}, \mathrm{m}, 6 \mathrm{x}$ adamantyl H), $1.49\left(3 \mathrm{H}, \mathrm{s}, \mathrm{CH}_{3}\right), 1.31\left(3 \mathrm{H}, \mathrm{s}, \mathrm{CH}_{3}\right) ;{ }^{13} \mathrm{C}$ NMR $\left(100 \mathrm{MHz}, \mathrm{DMSO}-d_{6}\right) \delta 161.3,158.9,154.4$, $151.9,147.7,139.8,131.1,128.5(\mathrm{~d}, J$ 7.9), $124.9(\mathrm{~d}, J 3.6), 121.8(\mathrm{~d}, J 17.1), 119.9,115.6(\mathrm{~d}, J 21.9)$, $113.2,89.5,85.1,83.4,83.2,52.2,41.0,36.0,34.4,29.0,26.8,25.1 ;{ }^{19} \mathrm{~F}$ NMR $\left(376 \mathrm{MHz}, \mathrm{DMSO}-d_{6}\right) \delta$ 110.4; HRMS $\left(\mathrm{ESI}^{+}\right) \mathrm{m} / z$ calcd for $\mathrm{C}_{29} \mathrm{H}_{35} \mathrm{~N}_{5} \mathrm{O}_{3} \mathrm{FS}[\mathrm{MH}]^{+}$552.2439, found 552.2425.

\section{6- $N$-[(3-endo)-9-Methyl-9-azabicyclo[3.3.1]non-3-yl]-5'-(2-fluorophenylthio)-2',3'-O-}

isopropylidene-5'-deoxyadenosine (31). 31 was synthesised according to the general procedure A, using chloride 29 (0.1 g, $0.23 \mathrm{mmol})$, (3-endo)-9-methyl-9-azabicyclo[3.3.1]nonan-3-amine (0.14 g, $0.92 \mathrm{mmol})$ and DIPEA (0.04 mL, $0.28 \mathrm{mmol})$. After purification with column chromatography (methanol/DCM, 5$10 \%)$ product 31 was obtained as a pale yellow solid (0.08 g, 61\% yield). ${ }^{1} \mathrm{H}$ NMR (400 MHz, $\left.\mathrm{CDCl}_{3}\right) \delta$ 
$8.33(1 \mathrm{H}, \mathrm{s}$, adenine $\mathrm{H}), 7.76(1 \mathrm{H}, \mathrm{s}$, adenine $\mathrm{H}), 7.36(1 \mathrm{H}, \mathrm{m}, \mathrm{Ar} \mathrm{H}), 7.20(1 \mathrm{H}, \mathrm{m}, \mathrm{Ar} \mathrm{H}), 7.04-6.97$ (2H, m, 2 x Ar H), $6.01(1 \mathrm{H}, \mathrm{d}, J$ 2.0, 1'-H), $5.54(1 \mathrm{H}, \mathrm{dd}, J$ 6.3, 1.9, 2'-H), 5.52 (1H overlapping with 2'-H signal, br s, NH), 5.10 (1H, dd, J 6.3, 2.8, 3'-H), 4.75 (1H, br s, 3-H), 4.37 (1H, td, J 7.2, 2.8, 4'-H), 3.25 (H, dd, $J$ 13.7, 7.6, 5-HH), $3.17(1 \mathrm{H}, \mathrm{dd}, J 13.7,6.5,5-\mathrm{HH}), 3.11(2 \mathrm{H}, \mathrm{m}, 1-$ and 5-H), 2.65-2.52 (2H, m, 2 x granatyl H), $2.50\left(3 \mathrm{H}, \mathrm{s}, \mathrm{NCH}_{3}\right), 2.04-1.91(3 \mathrm{H}, \mathrm{m}, 3 \mathrm{x}$ granatyl $\mathrm{H}), 1.56\left(3 \mathrm{H}, \mathrm{s}, \mathrm{CH}_{3}\right), 1.53(1 \mathrm{H}, \mathrm{m}$, granatyl $\mathrm{H}), 1.37\left(3 \mathrm{H}, \mathrm{s}, \mathrm{CH}_{3}\right), 1.35-1.29(2 \mathrm{H}, \mathrm{m}, 2 \mathrm{x}$ granatyl $\mathrm{H}), 1.02(2 \mathrm{H}, \mathrm{m}, 2 \mathrm{x}$ granatyl $\mathrm{H}) ;{ }^{13} \mathrm{C} \mathrm{NMR}$ $\left(75 \mathrm{MHz}, \mathrm{CDCl}_{3}\right) 163.5,160.2,154.6,153.5,139.3,133.3,129.2$ (d, $J$ 8.0), 124.5 (d, $\left.J 3.8\right), 122.0$ (d, $J$ 17.5), 115.9 (d, J 22.5), 114.3, 91.3, 86.6, 84.2, 84.1, 51.4, 40.3, 36.2, 33.6, 27.1, 25.4, 24.2, 14.4; ${ }^{19} \mathrm{~F}$ NMR (376 MHz, DMSO- $d_{6}$ ) $\delta$-108.4; HRMS calculated for $\mathrm{C}_{28} \mathrm{H}_{36} \mathrm{O}_{3} \mathrm{~N}_{6} \mathrm{FS}[\mathrm{MH}]^{+}$555.2548, found 555.2548; purity UPLC-MS 93\%, retention time $=2.88 \mathrm{~min}$.

\section{6- $N$-((1R,2R)-2-(Benzyloxy)cyclopentyl)-5'-(2-fluorophenylthio)-2',3'-O-isopropylidene-5'-}

deoxyadenosine (32). 32 was synthesised according to the general procedure A, using chloride 29 (0.05 g, $0.11 \mathrm{mmol}),(1 R, 2 R)$-1-amino-2-benzyloxycyclopentane $(0.03 \mathrm{~mL}, 0.17 \mathrm{mmol})$ and triethylamine $(0.04$ $\mathrm{mL}, 0.31 \mathrm{mmol}$ ). After purification with column chromatography (methanol/DCM, 2\%) product 32 was obtained as a sticky yellow oil (0.06 g, 99\% yield). ${ }^{1} \mathrm{H}$ NMR $\left(300 \mathrm{MHz}, \mathrm{DMSO}-d_{6}\right) \delta 8.32(1 \mathrm{H}$, s, adenine $\mathrm{H}), 8.26(1 \mathrm{H}$, br s, adenine $\mathrm{H}), 7.96(1 \mathrm{H}, \mathrm{m}$, amine $\mathrm{NH}), 7.39(1 \mathrm{H}, \mathrm{td}, J$ 7.8, 1.6, Ar H) , 7.32-7.06 (8H, m, 8 x Ar H), 6.19 (1H, d, $J$ 2.1, 1'-H), 5.51 (1H, dd, $J$ 6.2, 2.1, 2'-H), 5.07 (1H, dd, J 6.2, 2.6, 3'-H), 4.67$4.47\left(3 \mathrm{H}, \mathrm{m}, 1-\mathrm{H}\right.$ and $\left.\mathrm{CH}_{2} \mathrm{Ph}\right), 4.21(1 \mathrm{H}, \mathrm{td}, J$ 7.1, 2.6, 4'-H), $4.01(1 \mathrm{H}, \mathrm{m}, 2-\mathrm{H}), 3.25$ (2H overlapping with solvent signal, m, 5'- $\left.\mathrm{H}_{2}\right), 2.13-1.89$ (2H, m, 2 x cyclopentyl H), 1.79-1.57 (4H, m, 4 x cyclopentyl H), 1.49 $\left(3 \mathrm{H}, \mathrm{s}, \mathrm{CH}_{3}\right), 1.31\left(3 \mathrm{H}, \mathrm{s}, \mathrm{CH}_{3}\right) ;{ }^{13} \mathrm{C} \mathrm{NMR}\left(100 \mathrm{MHz}, \mathrm{DMSO}-d_{6}\right) \delta 161.3,158.9,154.2,152.5,147.9,139.8$, $138.9,131.1,128.5(\mathrm{~d}, J$ 7.9), 128.1, 127.3, 127.1, 124.9 (d, $J$ 3.5), 121.8 (d, J 17.1), $115.6(\mathrm{~d}, J 22.0)$, 113.2, 89.4, 85.2, 84.0, 83.4, 83.2, 70.1, 56.5, 34.4, 30.1, 26.8, 25.1, 21.4; ${ }^{19}$ F NMR (376 MHz, DMSO- $\left.d_{6}\right)$ $\delta$-110.4; HRMS (ESI) calculated for $\mathrm{C}_{31} \mathrm{H}_{35} \mathrm{O}_{4} \mathrm{~N}_{5} \mathrm{FS}[\mathrm{MH}]^{+}$592.2388, found 592.2378; purity UPLC-MS $94 \%$, retention time $=3.98 \mathrm{~min}$. 


\section{6- $N$-((1R,2R)-2-(Hydroxy)cyclopentyl)-5'-(2-fluorophenylthio)-2',3'-O-isopropylidene-5'-}

deoxyadenosine (33). 33 was synthesised according to the general procedure A using chloride 29 (0.05 g, $0.11 \mathrm{mmol}),(1 R, 2 R)$-2-aminocyclopentanol hydrochloride $(0.02 \mathrm{~g}, 0.14 \mathrm{mmol})$ and triethylamine $(0.04 \mathrm{~mL}$, $0.31 \mathrm{mmol}$ ). After purification with column chromatography (methanol/DCM, 2\%) product 33 was obtained as a white solid $\left(0.04 \mathrm{~g}, 73 \%\right.$ yield). ${ }^{1} \mathrm{H}$ NMR (300 MHz, DMSO- $\left.d_{6}\right) \delta 8.31(1 \mathrm{H}, \mathrm{s}$, adenine $\mathrm{H})$, $8.22(1 \mathrm{H}$, br s, adenine H), $7.76(1 \mathrm{H}, \mathrm{m}, \mathrm{NH}), 7.39(1 \mathrm{H}, \mathrm{td}, J 7.8,1.6, \operatorname{Ar} \mathrm{H}), 7.31-7.07(3 \mathrm{H}, \mathrm{m}, 3 \mathrm{x} \operatorname{Ar} \mathrm{H})$, $6.18\left(1 \mathrm{H}, \mathrm{d}, J\right.$ 2.1, 1'-H), $5.51\left(1 \mathrm{H}, \mathrm{dd}, J 6.2,2.1,2^{\prime}-\mathrm{H}\right), 5.06\left(1 \mathrm{H}, \mathrm{dd}, J 6.2,2.7,3^{\prime}-\mathrm{H}\right), 4.86$ (1H, m, 2$\mathrm{OH}), 4.27(1 \mathrm{H}$, br s, 1-H), $4.21(1 \mathrm{H}, \mathrm{td}, J$ 7.1, 2.6, 4'-H), $4.06(1 \mathrm{H}, \mathrm{m}, 2-\mathrm{H}), 3.26$ (2H overlapping with solvent signal, m, 5'- $\left.\mathrm{H}_{2}\right), 2.06(1 \mathrm{H}, \mathrm{m}, 1 \mathrm{x}$ cyclopentyl $\mathrm{H}), 1.89(1 \mathrm{H}, \mathrm{m}, 1 \mathrm{x}$ cyclopentyl $\mathrm{H}), 1.72-1.60(2 \mathrm{H}$, m, 2 x cyclopentyl H), 1.60-1.43 (5H, m, 2 x cyclopentyl $\mathrm{H}$ and $\left.\mathrm{CH}_{3}\right), 1.32\left(3 \mathrm{H}, \mathrm{s}, \mathrm{CH}_{3}\right) ;{ }^{13} \mathrm{C}$ NMR $(100$ MHz, DMSO- $\left.d_{6}\right) \delta 161.3,158.9,154.7,152.5,139.8,131.1,128.6(\mathrm{~d}, J$ 7.9), $124.9(\mathrm{~d}, J 3.5), 121.8(\mathrm{~d}, J$ 17.1), $115.6(\mathrm{~d}, J 22.0), 113.2,89.5,85.1,83.4,83.2,76.0,58.9,34.4,32.3,26.8,25.1,20.4 ;{ }^{19} \mathrm{~F} \mathrm{NMR}(376$ MHz, DMSO- $\left.d_{6}\right) \delta$-110.4; HRMS (ESI) calculated for $\mathrm{C}_{24} \mathrm{H}_{29} \mathrm{O}_{4} \mathrm{~N}_{5} \mathrm{FS}[\mathrm{MH}]^{+}$502.1919, found 502.1912; purity UPLC-MS 99\%, retention time $=3.14 \mathrm{~min}$.

6- $N$-(1-Adamantyl)-5'-(2-fluorophenylthio)-5'-deoxyadenosine (34). 34 was synthesised according to the general procedure $\mathrm{B}$, using $\mathbf{3 0}(0.01 \mathrm{~g}, 0.02 \mathrm{mmol})$, acetic acid $(3.2 \mathrm{~mL})$ and water $(0.8$ $\mathrm{mL}$ ). After purification with column chromatography (methanol/DCM, 1-3\%) product 34 was obtained as a white solid (0.004 g, 40\% yield). ${ }^{1} \mathrm{H}$ NMR $\left(400 \mathrm{MHz}, \mathrm{DMSO}-d_{6}\right) \delta 8.32(1 \mathrm{H}$, s, adenine $\mathrm{H}), 8.21(1 \mathrm{H}, \mathrm{s}$, adenine H), $7.46(1 \mathrm{H}, \mathrm{td}, J$ 7.8, 1.6, Ar H), 7.29-7.12 (3H, m, 3 x Ar H), $6.60(1 \mathrm{H}, \mathrm{s}, \mathrm{NH}), 5.87(1 \mathrm{H}, \mathrm{d}, J$ 5.7, 1'-H), $5.51(1 \mathrm{H}, \mathrm{d}, J$ 6.1, 2'-OH), $5.37(1 \mathrm{H}, \mathrm{d}, J$ 5.0, 3'-OH), $4.82(1 \mathrm{H}, \mathrm{dd}, J$ 11.1, 5.7, 2'-H), 4.22 (1H, dd, $J$ 8.7, 4.9, 3'-H), $4.00\left(1 \mathrm{H}, \mathrm{m}, 4^{\prime}-\mathrm{H}\right), 3.42(1 \mathrm{H}, \mathrm{dd}, J 13.8,5.5,5$ ' $-H \mathrm{H}), 3.31$ (1H overlapping with solvent signal, m, 5'-HH), $2.23(6 \mathrm{H}, \mathrm{m}, 6$ x adamantyl $\mathrm{H}), 2.10(3 \mathrm{H}, \mathrm{m}, 3$ x adamantyl H), $1.68(6 \mathrm{H}, \mathrm{m}, 6$ x adamantyl H); ${ }^{13} \mathrm{C}$ NMR (100 MHz, DMSO- $\left.d_{6}\right) \delta 161.1,158.7,154.4,151.9,148.5,139.7,130.5,128.1$ (d, J 7.9), $125.0(\mathrm{~d}, J 3.4), 122.6(\mathrm{~d}, J 17.1), 119.9,115.5(\mathrm{~d}, J 21.8), 87.7,82.8,72.7,72.5,52.1,41.0,36.0$, 
34.6, 29.0; ${ }^{19} \mathrm{~F}$ NMR (376 MHz, DMSO- $\left.d_{6}\right) \delta$-110.78; HRMS $\left(\mathrm{ESI}^{+}\right) \mathrm{m} / z$ calcd for $\mathrm{C}_{26} \mathrm{H}_{31} \mathrm{~N}_{5} \mathrm{O}_{3} \mathrm{FS}[\mathrm{MH}]^{+}$ 512.2126, found 512.2130.

\section{6- $N$-[(3-endo)-9-Methyl-9-azabicyclo[3.3.1]non-3-yl]-5'-(2-fluorophenylthio)-5'-}

deoxyadenosine (35). 35 was synthesised according to the general procedure B, using $31(0.01 \mathrm{~g}, 0.02$ mmol), acetic acid $(3.2 \mathrm{~mL})$ and water $(0.8 \mathrm{~mL})$. After purification with column chromatography (methanol/DCM, 1-10\%, with an additional 1\% aqueous ammonia) product $\mathbf{3 5}$ was obtained as a white solid (0.005 g, 50\% yield). ${ }^{1} \mathrm{H}$ NMR (400 MHz, MeOD- $\left.d_{4}\right) \delta 8.24(1 \mathrm{H}, \mathrm{s}$, adenine $\mathrm{H}), 8.17(1 \mathrm{H}$, s, adenine H), $7.45(1 \mathrm{H}, \mathrm{m}, \mathrm{Ar} H), 7.21(1 \mathrm{H}, \mathrm{m}, \mathrm{Ar} H), 7.07-7.01(2 \mathrm{H}, \mathrm{m}, 2$ x Ar H), $5.95(1 \mathrm{H}, \mathrm{d}, J$ 5.2, 1'-H), 4.84 $(1 \mathrm{H}, 2$ '- $\mathrm{H}$ under solvent signal as determined by COSY analysis), $4.83(1 \mathrm{H}, \mathrm{br}, 3-\mathrm{H}$, partially hidden by solvent signal), $4.37\left(1 \mathrm{H}, \mathrm{m}, 3^{\prime}-\mathrm{H}\right), 4.20\left(1 \mathrm{H}, \mathrm{m}, 4^{\prime}-\mathrm{H}\right), 3.40\left(2 \mathrm{H}, \mathrm{m}, \mathrm{CH}_{2} \mathrm{CH}_{3}\right), 3.31(2 \mathrm{H}, 1-$ and 5-H under solvent signal as determined by COSY analysis), 2.70-2.57 (5H, m, $\mathrm{NCH}_{3}$ and $2 \mathrm{x}$ granatyl $\left.\mathrm{H}\right), 2.16-2.04$ $\left(3 \mathrm{H}, \mathrm{m}, 3 \mathrm{x}\right.$ granatyl H), 1.69-1.59 (3H, m, 3 x granatyl H), 1.32-1.29 (2H, m, 2 x granatyl H); ${ }^{13} \mathrm{C}$ NMR $\left(100 \mathrm{MHz}, \mathrm{MeOD}-d_{4}\right) \delta 163.8,155.6,154.0,140.9,133.2,129.7$ (d, $J$ 7.9), 125.7 (d, $J$ 3.7), 116.5 (d, $J$ 22.5), 90.1, 85.0, 74.7, 74.1, 53.7, 40.2, 36.5, 32.9, 25.7, 14.3, 7.6; ${ }^{19} \mathrm{~F}$ NMR (376 MHz, DMSO- $\left.d_{6}\right) \delta$ 111.5; HRMS $\left(\mathrm{ESI}^{+}\right) \mathrm{m} / z$ calcd for $\mathrm{C}_{25} \mathrm{H}_{32} \mathrm{~N}_{6} \mathrm{O}_{3} \mathrm{FS}[\mathrm{MH}]^{+}$515.2235, found 515.2240; purity UPLC-MS $99 \%$, retention time $=2.24 \mathrm{~min}$.

\section{6- $N$-((1R,2R)-2-(Benzyloxy)cyclopentyl)-5'-(2-fluorophenylthio)-5'-deoxyadenosine (36). ${ }^{47} 36$}

was synthesised according to the general procedure $\mathrm{B}$, using $32(0.02 \mathrm{~g}, 0.03 \mathrm{mmol})$, acetic acid $(3.2 \mathrm{~mL})$ and water $(0.8 \mathrm{~mL})$. After purification with column chromatography (methanol/DCM, 1-3\%) product 36 was obtained as a pale yellow solid $\left(0.02 \mathrm{~g}, 99 \%\right.$ yield). ${ }^{1} \mathrm{H}$ NMR $\left(300 \mathrm{MHz}, \mathrm{DMSO}-d_{6}\right) \delta 8.35(1 \mathrm{H}, \mathrm{s}$, adenine $\mathrm{H}), 8.24(1 \mathrm{H}$, br s, adenine $\mathrm{H}), 7.89(1 \mathrm{H}, \mathrm{m}$, amine $\mathrm{NH}), 7.46(1 \mathrm{H}, \mathrm{m}, \mathrm{Ar} \mathrm{H}), 7.33-7.10(8 \mathrm{H}, \mathrm{m}, 8$ x Ar H), 5.90 (1H, d, J 5.6, 1'-H), 5.52 (1H, d, J 6.0, 2'-OH), 5.38 (1H, d, J 5.1, 3'-OH), 4.81 (1H, dd, $J$ 11.1, 5.6, 2'-H), 4.68-4.50 (3H, m, 1-H and $\left.\mathrm{CH}_{2} \mathrm{Ph}\right), 4.21(1 \mathrm{H}, \mathrm{dd}, J$ 8.7, 4.8, 3'-H), 4.00-3.97 (2H, m, 4'$\mathrm{H}$ and 2-H), $3.42\left(1 \mathrm{H}, \mathrm{dd}, J 13.8,5.5,5^{\prime}-H \mathrm{H}\right), 3.32$ (1H overlapping with solvent signal, $\left.\mathrm{m}, 5^{\prime}-\mathrm{H} H\right)$ 2.14$1.91\left(2 \mathrm{H}, \mathrm{m}, 2\right.$ x cyclopentyl H), 1.77-1.58 (4H, m, 4 x cyclopentyl H); ${ }^{13} \mathrm{C}$ NMR (100 MHz, DMSO- $\left.d_{6}\right) \delta$ 
$161.1,158.7,154.2,152.5,139.6,139.0,130.5,128.1,128.0,127.3,127.1,125.0$ (d, $J 3.4), 122.6$ (d, $J$ 17.2), 155.5 (d, J 21.9), 87.6, 84.1, 82.8, 72.7, 72.6, 70.1, 56.4, 34.6, 30.2, 21.4; ${ }^{19} \mathrm{~F}$ NMR (376 MHz, DMSO- $\left.d_{6}\right) \delta$-110.8; HRMS (ESI) calcd for $\mathrm{C}_{28} \mathrm{H}_{31} \mathrm{O}_{4} \mathrm{~N}_{5} \mathrm{FS}[\mathrm{MH}]^{+}$552.2075, found 552.2071; purity UPLCMS 99\%, retention time $=3.14 \mathrm{~min}$.

6- $N$-((1R,2R)-2-(Hydroxy)cyclopentyl)-5'-(2-fluorophenylthio)-5'-deoxyadenosine $(37) .{ }^{14} 37$ was synthesised according to the general procedure $\mathrm{B}$, using $33(0.01 \mathrm{~g}, 0.02 \mathrm{mmol})$, acetic acid (3.2 $\mathrm{mL})$ and water $(0.8 \mathrm{~mL})$. After purification with column chromatography (methanol/DCM, 1-5\%) product 37 was obtained as a white solid $(0.005 \mathrm{~g}, 56 \%$ yield $)$. The $O$-acetylated product was also isolated in small quantities. ${ }^{1} \mathrm{H}$ NMR (300 MHz, DMSO-d $) \delta 8.34(1 \mathrm{H}, \mathrm{s}$, adenine $\mathrm{H}), 8.21(1 \mathrm{H}$, br s, adenine $\mathrm{H}), 7.69(1 \mathrm{H}$, d, $J$ 7.1, amine NH), 7.47 (1H, td, J 7.8, 1.6, Ar H), 7.31-7.10 (3H, m, 3 x Ar H), 5.89 (1H, d, J 5.7, 1'-H), $5.54(1 \mathrm{H}, \mathrm{d}, J$ 6.0, 2'-OH), 5.40 (1H, d, $J$ 5.0, 3'-OH), 4.87 (1H, d, J 4.0, 2-OH), 4.80 (1H, dd, $J$ 10.9, 5.6, 2'-H), 4.30 (1H, br s, 1-H), 4.21 (1H, dd, J 8.6, 4.7, 3'-H), 4.09-3.95 (2H, m, 4'-H and 2-H), 3.42 (1H, dd, $J$ 13.7, 5.5, 5'-HH), $3.32\left(1 \mathrm{H}, \mathrm{m}, 5^{\prime}-\mathrm{H} H\right), 2.07(1 \mathrm{H}, \mathrm{m}, 1$ x cyclopentyl $\mathrm{H}), 1.90(1 \mathrm{H}, \mathrm{m}, 1$ x cyclopentyl H), 1.72-1.42 (4H, m, 4 x cyclopentyl H); ${ }^{13} \mathrm{C}$ NMR (100 MHz, DMSO- $\left.d_{6}\right) \delta 161.1,158.7,154.6,152.4$, 139.6, $130.5(\mathrm{~d}, J 1.7), 128.1(\mathrm{~d}, J 7.9), 125.0(\mathrm{~d}, J 3.4), 122.6$ (d, $J 17.1), 115.5(\mathrm{~d}, J 21.8), 87.6,82.8,76.1$, 72.7, 72.6, 58.8, 34.6, 32.3, 20.4; ${ }^{19} \mathrm{~F}$ NMR (376 MHz, DMSO- $\left.d_{6}\right) \delta-110.8$; HRMS (ESI) calcd for $\mathrm{C}_{21} \mathrm{H}_{25} \mathrm{O}_{4} \mathrm{~N}_{5} \mathrm{FS}[\mathrm{MH}]^{+}$462.1606, found 462.1590; purity UPLC-MS 95\%, retention time = 2.35 min.

Biology Materials. Yeast extract and yeast nitrogen base were purchased from Difco (Franklin Lakes, NJ). All other reagents were purchased from Sigma-Aldrich (St. Louis, MO).

Constructs and DNA Manipulation. p426-GPD-A $\mathrm{A}_{1}$ was kindly provided by Professor Arthur Christopoulos and Dr. Lauren May (Monash University, Australia). Mammalian expression vectors containing the $A_{1} R, A_{2 A} R, A_{2 B} R$ and $A_{3} R$ were purchased from Missouri S\&T cDNA Resource Center (http://cdna.org) (Rolla, MO). DNA manipulations were performed using standard techniques. Oligonucleotides were supplied by Invitrogen and PCR amplification performed using FastStart Taq 
polymerase (Roche Diagnostics, Burgess Hill, UK). All constructs generated by PCR were sequenced by GATC (GATC Biotech, London, UK) prior to use.

General Yeast Methods. General yeast procedures were performed as described previously. ${ }^{16}$ Cells were routinely cultured in YPDA (yeast, peptone, dextrose and adenine). Yeast transformations were achieved using the lithium acetate/single-stranded DNA/polyethylene glycol method as previously described. ${ }^{50}$ Cells were selected for uracil biosynthesis and routinely cultured in synthetic dropout media lacking uracil (SD-URA).

Yeast Strain Construction. The production of the dual reporter strains expressing chimeras of five C-terminal amino acids of human G $\alpha$ protein with the yeast Gpa1p, 1-467 (GPA1/G $\alpha$ ) has been described previously. ${ }^{16}$ Mammalian GPCRs were introduced into the yeast strains (MMY12, MMY14, MMY19, MMY22, MMY23, MMY25 and MMY28) using the p426-GPD expression plasmid. Positive isolates were selected upon their ability to generate $\beta$-galactosidase activity above basal when stimulated with $100 \mu \mathrm{M}$ NECA. For chimeric strains that did not initially appear to functionally couple ( $\mathrm{n} \geq 16$ isolates) to the ARs, expression and membrane localization were confirmed using fluorescence microscopy.

Yeast Reporter Gene Assay. Yeast cells were treated with compounds as described in Dowell and Brown. ${ }^{16}$ Initially cells were cultured overnight in SD-URA at $30^{\circ} \mathrm{C}$. Cells were diluted 1:10 in SD-URA and allowed to grow for 8 hours at $30^{\circ} \mathrm{C}$. Finally cell density was adjusted to an $\mathrm{OD}_{600}$ of 0.02 and treated with $1 \%(\mathrm{v} / \mathrm{v})$ of the appropriate compound dissolved in DMSO in a 96 -well plate for 16 hours at $30^{\circ} \mathrm{C}$. For compounds dissolved in other solvents the media was supplemented with $1 \%(\mathrm{v} / \mathrm{v})$ DMSO prior to treatment. To compensate for an elevated basal signal, the $\mathrm{A}_{2 \mathrm{~A}} \mathrm{R}$ was routinely cultured in SD-URA lacking histidine (SD-URA-HIS) and treatment media supplemented with 5mM 3-amino-triazole. All strains used in this study contain the lacZ gene under the control of the pheromone-responsive FUS1 promoter. To assess $\beta$-galactosidase activity cells were lysed as previously described. ${ }^{19,51-53}$ 2-Nitrophenyl $\beta$-Dgalactopyranoside (ONPG) was used as a chromogenic substrate for $\beta$-galactosidase and detected by $\mathrm{OD}_{430}$. Absorbance was measured using a Mithras LB940 microplate reader (Berthold Technologies, Harpenden, UK). The strains are $\Delta f a r l$ and are therefore incapable of cell cycle arrest induced by the pheromone- 
response. Consequently, these cells grow throughout treatment. To compensate for variability in cell number and bleed through from the chromogenic reporter, cell density was measured by $\mathrm{OD}_{620}$ and a response calculated as $\left(\mathrm{OD}_{430}-\mathrm{OD}_{620}\right) / \mathrm{OD}_{620}$.

Confocal Microscopy of Yeast. To visual receptor expression C-terminal in-frame fusion constructs between the $A_{1} R, A_{2 A} R$ and $A_{2 B} R$ and GFP was generated using the two-step cloning method described by Ladds et al. ${ }^{54}$ These receptors were expressed in yeast using p426-GPD vector consistent with their untagged counterparts. Isolates were cultured for $24 \mathrm{~h}$ in SD-URA. $100 \mu \mathrm{L}$ cells were harvested by centrifugation, washed in PBS and briefly sonicated. Cells were imaged using a True Confocal Scanner Leica TCS SP5 microscope (Leica Microsystems Ltd., Milton Keynes, UK) and were processed using ImageJ as described previously. ${ }^{55}$

Mammalian Cell Culture and Transfection. CHO-K1 cells, provided by Dr Ewan St. John Smith (University of Cambridge), were routinely cultured in Hams-F12, supplemented with $10 \%$ fetal bovine serum (FBS), and maintained at $37^{\circ} \mathrm{C}$, in humidified air with $5 \% \mathrm{CO}_{2}$. Cells were transfected with $2 \mu \mathrm{g}$ DNA using FuGene® 6 at a 3:1 (w:v) DNA:FuGene 6 ratio. Cells were harvested 48 h post transfection for assaying.

cAMP Accumulation Assay. Transfected cells were washed with PBS and resuspended in stimulation buffer (PBS containing 0.1\% BSA and $25 \mu \mathrm{M}$ rolipram). Cells were seeded at 2500 cells per well in 384-well white Optiplates. Cells were then simultaneously incubated with $10 \mu \mathrm{M}$ forskolin (to stimulate cAMP production) and adenosine receptors ligands (ranging between $1 \mu \mathrm{M}$ to $10 \mathrm{pM}$ ) for $30 \mathrm{~min}$ at room temperature. Cells were then lysed and the extent of cAMP accumulation measured using a LANCE® cAMP Detection Kit (PerkinElmer). Plates were read using a Mithras LB 940 multimode plate reader (Berthold Technologies).

Data Analysis. Data were analyzed using Prism 6.0e (Graphpad Software, San Diego, CA). Concentration response curves were fitted using the three-parameter logistic equation to obtain $\mathrm{EC}_{50}$ and $E_{\max }$. Schild analysis was performed in Prism as described by Motulsky and Christopoulos. ${ }^{56}$ Non-linear regression of the operational model of pharmacological agonism ${ }^{36}$ was used to obtain values for efficacy 
$(\log \tau)$ and the equilibrium dissociation constant $\left(\log K_{\mathrm{A}}\right)$. These values were then used to quantify signaling bias as the change in $\log \left(\tau / K_{\mathrm{A}}\right)$ relative to NECA. ${ }^{37}$ We have used this method previously to enable quantification of $\mathrm{G}$ protein bias ${ }^{19,20}$ but here we have extended the analysis to include receptor selectivity. Since the receptors are expressed in the same cell background, and that NECA is a full potent agonist against all receptor subtypes, we reasoned that changes in $\log \left(\tau / K_{\mathrm{A}}\right)$ for a given ligand, relative to NECA for each $\mathrm{AR}$ would provide a quantitative means of comparing receptor selectivity. Statistically significant differences were detected using one-way ANOVA with Bonferroni's or Dunnett's multiple comparison tests or Student T-tests as appropriate and a probability $(p)<0.05$ was considered significant.

Homology Modeling and Docking. The protein sequence of the human $\mathrm{A}_{1} \mathrm{R}$ (accession number P30542) was aligned with an agonist (UK-432097)-bound human $\mathrm{A}_{2 \mathrm{~A}} \mathrm{R}$ template (PDB ID: 3QAK) using PSI-Coffee ${ }^{57}$ (Figure S4). MODELLER v9.14 ${ }^{58}$ was used to build 500 models and the best model selected according to the inbuilt molecular probability function. The ligands were constructed $a b$ initio in Chem3D Pro v14.0 (PerkinElmer, Waltham, MA) and energy-minimised using the included MM2 force field. For each ligand a library of 200 conformers was generated using OMEGA v2.5 (OpenEye Scientific Software, Santa Fe, NM). FRED RECEPTOR v2.2.5 (OpenEye Scientific Software) was utilized to generate a docking template whereas the binding site was defined as a box of V = 9486 $\AA^{3}$ around the bound UK432097 agonist. For predicting the binding poses, the ligands were docked into this binding site template using FRED v2.1 (OpenEye Scientific Software) that utilizes an exhaustive process to position and score all conformers of a ligand at all possible positions within the defined binding site. Binding poses that did not form a hydrogen bond with either Thr- $91^{3.36}$, Asn- $254^{6.55}$ or Thr- $277^{7.42}$ were discarded $\left(h \mathrm{~A}_{1} \mathrm{R}\right.$ numbering according to P30542, superscript: Ballesteros-Weinstein numbering ${ }^{45}$ ). Ten docking poses were generated for each ligand, ranked using the inbuilt Chemgauss 3 scoring function and visualized with PyMOL v1.7 (Schrödinger LLC, Portland, OR). 


\section{Supporting Information}

Synthesis procedures and spectral data for synthetic intermediates, reproduction of ${ }^{1} \mathrm{H}$ and ${ }^{13} \mathrm{C}$ NMR spectra, purity assessment for final compounds, Schild analysis of compounds $\mathbf{3 6}$ and 37, functional assessment of $A_{3} R$ in yeast and predicted docking poses for compounds. This material is available free of charge via the Internet at http://pubs.acs.org.

\section{Author information}

Corresponding authors:

*M.L.: phone +41 31631 3311; fax +41 31631 4272; E-mail martin.lochner@ dcb.unibe.ch

*G.L.: phone +44 1223 334020; fax +44 1223 334100; E-mail grl30@ cam.ac.uk

Notes:

The authors declare no competing financial interest.

${ }^{\#}$ A.K. and J.L.H. contributed equally to this work.

\section{Acknowledgments}

This study was supported by the Swiss National Science Foundation (SNSF professorship PP00P2_123536 and PP00P2_146321 to M.L.), the BBSRC (G.L., BB/G01227X/1 and BB/M00015X/1), an MRC Doctoral Training Partnership (I.W. MR/J003964/1), and the EPSRC (A.K., EP/G500045/1). 


\section{Abbreviations Used}

$A R$, adenosine receptor; $A_{1} R, A_{1}$ adenosine receptor; $A_{2 A} R, A_{2 A}$ adenosine receptor; $A_{2 B} R, A_{2 B}$ adenosine receptor; $\mathrm{A}_{3} \mathrm{R}, \mathrm{A}_{3}$ adenosine receptor; CCPA, 2-chloro- $N^{6}$-cyclopentyladenosine; DIPEA, di-iso-propyl ethyl amine (Hünig's base); GAPDH, glyceraldehyde-3-phosphate dehydrogenase; Gpa1p, guanine nucleotide-binding protein alpha-1 subunit; NECA, 5'- $N$-ethylcarboxamidoadenosine. 


\section{References}

(1) Sachdeva, S.; Gupta, M. Adenosine and its receptors as therapeutic targets: an overview. Saudi Pharm. J. 2013, 21, 245-253.

(2) Dale, N.; Frenguelli, B. G. Release of adenosine and ATP during ischemia and epilepsy. Curr. Neuropharmacol. 2009, 7, 160-179.

(3) Fredholm, B. B.; Chen, J.-F.; Cunha, R. A.; Svenningsson, P.; Vaugeois, J.-M. Adenosine and brain function. Int. Rev. Neurobiol. 2005, 63, 191-270.

(4) Chen, J.-F.; Sonsalla, P. K.; Pedata, F.; Melani, A.; Domenici, M. R.; Popoli, P.; Geiger, J.; Lopes, L. V.; de Mendonça, A. Adenosine $\mathrm{A}_{2 \mathrm{~A}}$ receptors and brain injury: broad spectrum of neuroprotection, multifaceted actions and "fine tuning" modulation. Progr. Neurobiol. 2007, 83, 310-331.

(5) Stewart, G. D.; Valant, C.; Dowell, S. J.; Mijaljica, D.; Devenish, R. J.; Scammells, P. J.; Sexton, P. M.; Christopoulos, A. Determination of adenosine $A_{1}$ receptor agonist and antagonist pharmacology using Saccharomyces cerevisiae: implications for ligand screening and functional selectivity. J. Pharmacol. Exp. Ther. 2009, 331, 277-286.

(6) Nell, P. G.; Albrecht-Küpper, B. The adenosine $\mathrm{A}_{1}$ receptor and its ligands. Progr. Med. Chem. 2009, 47, 163-201.

(7) Petrelli, R.; Torquati, I.; Kachler, S.; Luongo, L.; Maione, S.; Franchetti, P.; Grifantini, M.; Novellino, E.; Lavecchia, A.; Klotz, K.-N.; Cappellacci, L. 5'-C-Ethyl-tetrazolyl- $N^{6}$-substituted adenosine and 2-chloro-adenosine derivatives as highly potent dual acting $\mathrm{A}_{1}$ adenosine receptor agonists and $\mathrm{A}_{3}$ adenosine receptor antagonists. J. Med. Chem. 2015, 58, 2560-2566.

(8) Franchetti, P.; Cappellacci, L.; Vita, P.; Petrelli, R.; Lavecchia, A.; Kachler, S.; Klotz, K.-N.; Marabese, I.; Luongo, L.; Maione, S.; Grifantini, M. $N^{6}$-Cycloalkyl- and $N^{6}$-bicycloalkyl-C5'(C2')- 
modified adenosine derivatives as high-affinity and selective agonists at the human $\mathrm{A}_{1}$ adenosine receptor with antinociceptive effects in mice. J. Med. Chem. 2009, 52, 2393-2406.

(9) Ashton, T. D.; Aumann, K. M.; Baker, S. P.; Schiesser, C. H.; Scammells, P. J. Structure-activity relationships of adenosines with heterocyclic $N^{6}$-substituents. Bioorg. Med. Chem. Lett. 2007, 17, 67796784.

(10) Hutchinson, S. A.; Baker, S. P.; Scammells, P. J. Adenosine receptor ligands with oxygenated $N^{6}-$ substituents. Bioorg. Med. Chem. Lett. 1999, 9, 933-936.

(11) Cappellacci, L.; Franchetti, P.; Pasqualini, M.; Petrelli, R.; Vita, P.; Lavecchia, A.; Novellino, E.; Costa, B.; Martini, C.; Klotz, K.-N.; Grifantini, M. Synthesis, biological evaluation, and molecular modeling of ribose-modified adenosine analogues as adenosine receptor agonists. J. Med. Chem. 2005, 48, $1550-1562$.

(12) Cappellacci, L.; Franchetti, P.; Vita, P.; Petrelli, R.; Lavecchia, A.; Costa, B.; Spinetti, F.; Martini, C.; Klotz, K.-N.; Grifantini, M. 5'-Carbamoyl derivatives of 2'-C-methyl-purine nucleosides as selective $A_{1}$ adenosine receptor agonists: affinity, efficacy, and selectivity for $A_{1}$ receptor from different species. Bioorg. Med. Chem. 2008, 16, 336-353.

(13) Morrison, C. F.; Elzein, E.; Jiang, B.; Ibrahim, P. N.; Marquart, T.; Palle, V.; Shenk, K. D.; Varkhedkar, V.; Maa, T.; Wu, L.; Wu, Y.; Zeng, D.; Fong, I.; Lustig, D.; Leung, K.; Zablocki, J. A. Structure-affinity relationships of 5'-aromatic ethers and 5'-aromatic sulfides as partial $\mathrm{A}_{1}$ adenosine agonists, potential supraventricular anti-arrhythmic agents. Bioorg. Med. Chem. Lett. 2004, 14, 3793-3797.

(14) Fatholahi, M.; Xiang, Y.; Wu, Y.; Li, Y.; Wu, L.; Dhalla, A. K.; Belardinelli, L.; Shryock, J. C. A novel partial agonist of the $\mathrm{A}_{1}$-adenosine receptor and evidence of receptor homogeneity in adipocytes. $J$. Pharmacol. Exp. Ther. 2006, 317, 676-684. 
(15) Brown, A. J.; Dyos, S. L.; Whiteway, M. S.; White, J. H. M.; Watson, M.-A. E. A.; Marzioch, M.; Clare, J. J.; Cousens, D. J.; Paddon, C.; Plumpton, C.; Romanos, M. A.; Dowell, S. J. Functional coupling of mammalian receptors to the yeast mating pathway using novel yeast/mammalian G protein $\alpha$-subunit chimeras. Yeast 2000, 16, 11-22.

(16) Dowell, S. J.; Brown, A. J. Yeast assays for G-protein-coupled receptors. Receptors Channels 2002, $8,343-352$.

(17) Brown, A. J.; Goldsworthy, S. M.; Barnes, A. A.; Eilert, M. M.; Tcheang, L.; Daniels, D.; Muir, A. I.; Wigglesworth, M. J.; Kinghorn, I.; Fraser, N. J.; Pike, N. B.; Strum, J. C.; Steplewski, K. M.; Murdock, P. R.; Holder, J. C.; Marshall, F. H.; Szekeres, P. G.; Wilson, S.; Ignar, D. M.; Foord, S. M.; Wise, A.; Dowell, S. J. The orphan G protein-coupled receptors GPR41 and GPR43 are activated by propionate and other short chain carboxylic acids. J. Biol. Chem. 2003, 278, 11312-11319.

(18) Bertheleme, N.; Singh, S.; Dowell, S. J.; Hubbard, J.; Byrne, B. Loss of constitutive activity is correlated with increased thermostability of the human adenosine $\mathrm{A}_{2 \mathrm{~A}}$ receptor. Br. J. Pharmacol. 2013, $169,988-998$.

(19) Weston, C.; Poyner, D.; Patel, V.; Dowell, S.; Ladds, G. Investigating G protein signalling bias at the glucagon-like peptide-1 receptor in yeast. Br. J. Pharmacol. 2014, 171, 3651-3665.

(20) Weston, C.; Lu, J.; Li, N.; Barkan, K.; Richards, G. O.; Roberts, D. J.; Skerry, T. M.; Poyner, D.; Pardamwar, M.; Reynolds, C. A.; Dowell, S. J.; Willars, G. B.; Ladds, G. Modulation of glucagon receptor pharmacology by receptor activity-modifying protein-2 (RAMP2). J. Biol. Chem. 2015, 290, 23009-23022.

(21) Peeters, M. C.; van Westen, G. J. P.; Guo, D.; Wisse, L. E.; Müller, C. E.; Beukers, M. W.; Ijzerman, A. P. GPCR structure and activation: an essential role for the first extracellular loop in activating the adenosine $\mathrm{A}_{2 \mathrm{~B}}$ receptor. FASEB J. 2011, 25, 632-643. 
(22) Peeters, M. C.; Wisse, L. E.; Dinaj, A.; Vroling, B.; Vriend, G.; Ijzerman, A. P. The role of the second and third extracellular loops of the adenosine $\mathrm{A}_{1}$ receptor in activation and allosteric modulation. Biochem. Pharmacol. 2012, 84, 76-87.

(23) Liu, R.; Groenewoud, N. A.; Peeters, M.; Lenselink, E.; Ijzerman, A. A yeast screening method to decipher the interaction between the adenosine $\mathrm{A}_{2 \mathrm{~B}}$ receptor and the $\mathrm{C}$-terminus of different $\mathrm{G}$ protein $\alpha$ subunits. Purinergic Signal. 2014, 10, 441-453.

(24) Ladds, G.; Goddard, A.; Davey, J. Functional analysis of heterologous GPCR signalling pathways in yeast. Trends Biotechnol. 2005, 23, 367-373.

(25) Brown, A. J.; Daniels, D. A.; Kassim, M.; Brown, S.; Haslam, C. P.; Terrell, V. R.; Brown, J.; Nichols, P. L.; Staton, P. C.; Wise, A.; Dowell, S. J. Pharmacology of GPR55 in yeast and identification of GSK494581A as a mixed-activity glycine transporter subtype 1 inhibitor and GPR55 agonist. J. Pharmacol. Exp. Ther. 2011, 337, 236-246.

(26) Gao, Z.-G.; Blaustein, J. B.; Gross, A. S.; Melman, N.; Jacobson, K. A. $N^{6}$-Substituted adenosine derivatives: selectivity, efficacy, and species differences at $\mathrm{A}_{3}$ adenosine receptors. Biochem. Pharmacol. 2003, 65, 1675-1684.

(27) Jagtap, P.; Andover, N. Adenosine compounds and their use thereof. WO2011/119919 A1, 2011.

(28) Knutsen, L. J. S.; Lau, J.; Petersen, H.; Thomsen, C.; Weis, J. U.; Shalmi, M.; Judge, M. E.; Hansen, A. J.; Sheardown, M. J. $N$-Substituted adenosines as novel neuroprotective $\mathrm{A}_{1}$ agonists with diminished hypotensive effects. J. Med. Chem. 1999, 42, 3463-3477.

(29) Kotra, L. P.; Manouilov, K. K.; Cretton-Scott, E.; Sommadossi, J.-P.; Boudinot, F. D.; Schinazi, R. F.; Chu, C. K. Synthesis, biotransformation, and pharmacokinetic studies of 9-( $\beta$-D-arabinofuranosyl)-6azidopurine: a prodrug for ara-A designed to utilize the azide reduction pathway. J. Med. Chem. 1996, 39, 5202-5207. 
(30) Vernekar, S. K. V.; Hallaq, H. Y.; Clarkson, G.; Thompson, A. J.; Silvestri, L.; Lummis, S. C. R.; Lochner, M. Toward biophysical probes for the 5- $\mathrm{HT}_{3}$ receptor: structure-activity relationship study of granisetron derivatives. J. Med. Chem. 2010, 53, 2324-2328.

(31) Gao, Z.-G.; Mamedova, L. K.; Chen, P.; Jacobson, K. A. 2-Substituted adenosine derivatives: affinity and efficacy at four subtypes of human adenosine receptors. Biochem. Pharmacol. 2004, 68, 19851993.

(32) Middleton, R. J.; Briddon, S. J.; Cordeaux, Y.; Yates, A. S.; Dale, C. L.; George, M. W.; Baker, J. G.; Hill, S. J.; Kellam, B. New fluorescent adenosine $A_{1}$-receptor agonists that allow quantification of ligand-receptor interactions in microdomains of single living cells. J. Med. Chem. 2007, 50, 782-793.

(33) Yang, Z.; Manning, D. D. 2-Alkylbenzoxazole carboxamides as 5-HT 3 modulators. US2008/0214601 A1, 2008.

(34) Verheyden, J. P. H.; Moffatt, J. G. Halo sugar nucleosides. III. Reactions for the chlorination and bromination of nucleoside hydroxyl groups. J. Org. Chem. 1972, 37, 2289-2299.

(35) Ijzerman, A. P.; Fredholm, B. B.; Jacobson, K. A.; Linden, J.; Müller, C. E. Adenosine receptors: $\mathrm{A}_{1}$ receptor. Last modified on 23/07/2015. Accessed on 14/08/2015. IUPHAR/BPS Guide to PHARMACOLOGY, http://www.guidetopharmacology.org/GRAC/ObjectDisplayForward?objectId=18.

(36) Black, J. W.; Leff, P. Operational models of pharmacological agonism. Proc. R. Soc. Lond. B. Biol. Sci. 1983, 220, 141-162.

(37) Figueroa, K. W.; Griffin, M. T.; Ehlert, F. J. Selectivity of agonists for the active state of M1 to M4 muscarinic receptor subtypes. J. Pharmacol. Exp. Ther. 2009, 328, 331-342.

(38) Gurden, M. F.; Coates, J.; Ellis, F.; Evans, B.; Foster, M.; Hornby, E.; Kennedy, I.; Martin, D. P.; Strong, P.; Vardey, C. J.; Wheeldon, A. Functional characterization of three adenosine receptor types. $B r$. J. Pharmacol. 1993, 109, 693-698. 
(39) Colca, J. R. Discontinued drugs 2011: endocrine and metabolic. Exp. Opin. Investig. Drugs 2012, $21,1619-1624$.

(40) Yang, M.; Chu, R.; Chisholm, J. W.; Doege, H.; Belardinelli, L.; Dhalla, A. K. Adenosine A $_{1}$ receptors do not play a major role in the regulation of lipogenic gene expression in hepatocytes. Eur. $J$. Pharmacol. 2012, 683, 332-339.

(41) Cordeaux, Y.; Briddon, S. J.; Alexander, S. P. H.; Kellam, B.; Hill, S. J. Agonist-occupied A 3 adenosine receptors exist within heterogeneous complexes in membrane microdomains of individual living cells. FASEB J. 2008, 22, 850-860.

(42) Baker, J. G.; Hill, S. J. A comparison of the antagonist affinities for the $\mathrm{G}_{\mathrm{i}}$ and $\mathrm{G}_{\mathrm{s}}$-coupled states of the human adenosine $\mathrm{A}_{1}$-receptor. J. Pharmacol. Exp. Ther. 2007, 320, 218-228.

(43) Xu, F.; Wu, H.; Katritch, V.; Han, G. W.; Jacobson, K. A.; Gao, Z.-G.; Cherezov, V.; Stevens, R. C. Structure of an agonist-bound human $\mathrm{A}_{2 \mathrm{~A}}$ adenosine receptor. Science 2011, 332, 322-327.

(44) Lebon, G.; Warne, T.; Edwards, P. C.; Bennett, K.; Langmead, C. J.; Leslie, A. G. W.; Tate, C. G. Agonist-bound adenosine $\mathrm{A}_{2 \mathrm{~A}}$ receptor structures reveal common features of GPCR activation. Nature 2011, $474,521-525$.

(45) Ballesteros, J. A.; Weinstein, H. Integrated methods for the construction of three-dimensional models and computational probing of structure-function relations in $G$ protein-coupled receptors. In Methods in Neurosciences; Stuart, C. S., Ed.; Academic Press: San Diego, 1995; Vol. 25, pp 366-428.

(46) Yuan, S.; Hu, Z.; Filipek, S.; Vogel, H. W246 ${ }^{6.48}$ opens a gate for a continuous intrinsic water pathway during activation of the adenosine $\mathrm{A}_{2 \mathrm{~A}}$ receptor. Angew. Chem. Int. Ed. 2015, 54, 556-559.

(47) Elfatih, E.; Prabha, I.; Venkata, P.; Vaibhav, V.; Zablocki, J. Partial and full agonists of $\mathrm{A}_{1}$ adenosine receptors. US2005/0020532 A1, 2005. 
(48) Hong, C. I.; Tritsch, G. L.; Mittelman, A.; Hebborn, P.; Chheda, G. B. Synthesis and antitumor activity of 5'-phosphates and cyclic 3',5'-phosphates derived from biologically active nucleosides. J. Med. Chem. 1975, 18, 465-473.

(49) Zablocki, J.; Elfatih, E.; Organ, M.; Bilokin, Y.; Mayer, S.; Disanti, A.; Miller, S.; Kernast, P. Partial and full agonists of $\mathrm{A}_{1}$ receptors. US2006/0052330 A1, 2006.

(50) Gietz, R. D.; Schiestl, R. H. Microtiter plate transformation using the LiAc/SS carrier DNA/PEG method. Nat. Protocols 2007, 2, 35-37.

(51) Dohlman, H. G.; Apaniesk, D.; Chen, Y.; Song, J.; Nusskern, D. Inhibition of G-protein signaling by dominant gain-of-function mutations in Sst2p, a pheromone desensitization factor in Saccharomyces cerevisiae. Mol. Cell. Biol. 1995, 15, 3635-43.

(52) Didmon, M.; Davis, K.; Watson, P.; Ladds, G.; Broad, P.; Davey, J. Identifying regulators of pheromone signalling in the fission yeast Schizosaccharomyces pombe. Curr. Genet. 2002, 41, 241-253.

(53) Ladds, G.; Davis, K.; Hillhouse, E. W.; Davey, J. Modified yeast cells to investigate the coupling of G protein-coupled receptors to specific G proteins. Mol. Microbiol. 2003, 47, 781-792.

(54) Ladds, G.; Davis, K.; Das, A.; Davey, J. A constitutively active GPCR retains its G protein specificity and the ability to form dimers. Mol. Microbiol. 2005, 55, 482-497.

(55) Croft, W.; Hill, C.; McCann, E.; Bond, M.; Esparza-Franco, M.; Bennett, J.; Rand, D.; Davey, J.; Ladds, G. A physiologically required G protein-coupled receptor (GPCR)-regulator of G protein signaling (RGS) interaction that compartmentalizes RGS activity. J. Biol. Chem. 2013, 288, 27327-27342.

(56) Motulsky, H. A.; Christopoulos, A. Fitting models to biological data using linear and nonlinear regression: a practical guide to curve fitting; Oxford University Press: New York, 2004.

(57) Notredame, C.; Higgins, D. G.; Heringa, J. T-coffee: a novel method for fast and accurate multiple sequence alignment. J. Mol. Biol. 2000, 302, 205-217. 
(58) Webb, B.; Sali, A. Comparative protein structure modeling using MODELLER. In Current Protocols in Bioinformatics; John Wiley \& Sons, Inc.: 2002.

\section{Table of Contents Graphic}

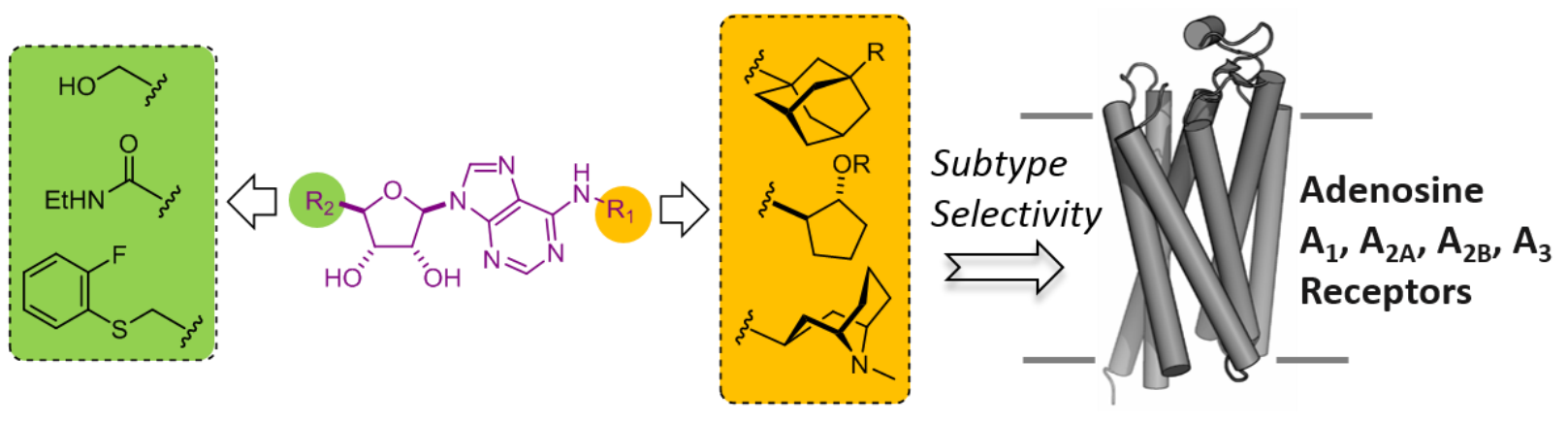

